\title{
Tailoring Multi-component Catalysts on Carbon Supports for Fischer-Tropsch Products in the Kerosene Range
}

Joshua B. Welshans

West Virginia University

Follow this and additional works at: https://researchrepository.wvu.edu/etd

\section{Recommended Citation}

Welshans, Joshua B., "Tailoring Multi-component Catalysts on Carbon Supports for Fischer-Tropsch Products in the Kerosene Range" (2011). Graduate Theses, Dissertations, and Problem Reports. 2232. https://researchrepository.wvu.edu/etd/2232

This Thesis is protected by copyright and/or related rights. It has been brought to you by the The Research Repository @ WVU with permission from the rights-holder(s). You are free to use this Thesis in any way that is permitted by the copyright and related rights legislation that applies to your use. For other uses you must obtain permission from the rights-holder(s) directly, unless additional rights are indicated by a Creative Commons license in the record and/ or on the work itself. This Thesis has been accepted for inclusion in WVU Graduate Theses, Dissertations, and Problem Reports collection by an authorized administrator of The Research Repository @ WVU. For more information, please contact researchrepository@mail.wvu.edu. 


\title{
Tailoring Multi-component Catalysts on Carbon Supports for Fischer-Tropsch Products in the Kerosene Range
}

\author{
Joshua B Welshans
}

\author{
Thesis submitted to the \\ College of Engineering and Mineral Resources \\ at West Virginia University \\ in partial fulfillment of the requirements \\ for the degree of \\ Master of Science \\ in \\ Chemical Engineering
}

\author{
Advisory Committee \\ Dady B. Dadyburjor, Ph.D. \\ Edwin L. Kugler, Ph.D. \\ John W. Zondlo, Ph.D.
Department of Chemical Engineering Morgantown, West Virginia 2011

Keywords: Fischer-Tropsch Synthesis, Iron Catalysts, Water Gas Shift 


\section{ABSTRACT \\ Tailoring Multi-component Catalysts on Carbon Supports for Fischer-Tropsch Products in the Kerosene Range}

\section{Joshua B Welshans}

The effects of varying the loading of four promoters on activated carbon supported iron catalysts were investigated. The base case catalyst studied consists of 6 wt $\%$ Mo, 16 wt\% Fe, 0.8 wt\% Cu and 0.9 wt\% K. Molybdenum loadings of 0 wt\%, 3 wt $\%, 6 \mathrm{wt} \%$ and $12 \mathrm{wt} \%$ were studied along with iron loadings of $0 \mathrm{wt} \%$, $8 \mathrm{wt} \%, 16 \mathrm{wt} \%$ and $32 \%$, copper loadings of $0 \mathrm{wt} \%, 0.4 \mathrm{wt} \%, 0.8 \mathrm{wt} \%$ and $1.6 \mathrm{wt} \%$, and potassium loadings of $0 \mathrm{wt} \%, 0.45 \mathrm{wt} \%, 0.9 \mathrm{wt} \%$ and $1.8 \mathrm{wt} \%$. The reactor conditions used were $300^{\circ} \mathrm{C}, 300 \mathrm{psig}$, and $6 \mathrm{Nl} / \mathrm{gcat} / \mathrm{h}$. The syngas used had a $\mathrm{H}_{2} / \mathrm{CO}$ ratio of 1.0 . The reaction was carried out over a period of 72 hours.

Data were gathered on the gaseous products and the two phases of the liquid products, the aqueous phase (containing oxygenates such as alcohols) and the oil phase (containing hydrocarbons such as paraffins and olefins). The data reported in this thesis were taken from the 24-48 hour period. The data gathered were fitted in a regression model. Catalysts were characterized using BET, XRD and TPR. Results were also compared to similar studies, but with simpler catalyst formulations.

The addition of Mo lowers CO conversion, but increases stability. The oxygenate production has a maximum at 6\% Mo. An increase in Mo loading corresponds to a decrease in oil production. An increase in Fe loading causes an increase in CO conversion. Changes in the Fe loading do not significantly effect aqueous production. Increases in Fe content causes an increase in oil production. Changes in $\mathrm{Cu}$ loading have little effect on all parameters. The absence of $\mathrm{K}$ in the catalyst causes a very low conversion while all other $\mathrm{K}$ catalysts have comparable $\mathrm{CO}$ conversions. Increasing the $\mathrm{K}$ loading causes an increase in oil production.

Equations for the CO conversion, oil fraction yield, hydrocarbon production rate, olefin-to-paraffin ratio, gasoline range production and diesel range production were fitted. The oil fraction yield and olefin-to-paraffin ratio equations were very good fits to the data while the other equations did not fit the data as well. 


\section{ACKNOWLEDGEMENTS}

I would like to thank my advisors, Dr. Dadyburjor and Dr. Kugler, for their encouragement, support and great patience. I would also like to thank the entire chemical engineering department's faculty and staff for their assistance and kindness over the years. Specifically, I would like to thank Liviu Magean, Adrienne McGraw and Gabriela Perchinschi for their help with the XRD, SEM and EDS analysis. I would also like to thank Dr. Alaa Kababji for his help with the BET, TPR and liquid product GC analysis.

I would like to acknowledge the financial support afforded me by the Department of Defense, it was greatly appreciated. 


\section{Table of Contents}

Title Page $\quad$ i

Abstract $\quad$ ii

Acknowledgements $\quad$ iii

Table of Contents $\quad$ iv

List of Tables $\quad$ vi

List of Figures viii

Chapter 1 Introduction 1

Chapter 2 Literature Review $\quad 4$

2.1 Fischer-Tropsch Catalysts 4

2.1.1 Catalysts 4

2.1.2 Promoters 5

$\begin{array}{ll}\text { 2.1.3 Catalyst Pretreatment } & 6\end{array}$

$\begin{array}{ll}\text { 2.1.4 Catalyst Poisoning } & 7\end{array}$

2.2 Selectivity 8

2.2.1 The Anderson-Schulz-Flory Distribution 9

2.2.2 Deviations from the ASF Distribution 10

$\begin{array}{ll}2.3 \text { Related WVU Laboratory Work } & 11\end{array}$

Chapter 3 Experimental Equipment and Procedure 15

$\begin{array}{ll}3.1 \text { Materials } & 15\end{array}$

3.2 Equipment 16

3.2.1 Reactor System 16

3.2.2 Analysis of Reactor Outlet 19

$\begin{array}{ll}\text { 3.2.3 Catalyst Characterization } & 20\end{array}$

$\begin{array}{ll}3.3 \text { Experimental Procedure } & 22\end{array}$

3.3.1 Catalyst Preparation $\quad 22$

3.3.2 Reactor Procedure 23

3.3.3 Liquid Product Analysis Procedure 25

$\begin{array}{ll}3.4 \text { Safety } & 27\end{array}$

Chapter 4 Results and Discussion $\quad 29$ 
4.1 Effect of Varying Mo 30

4.2 Effect of Varying Fe 34

4.3 Effect of Varying $\mathrm{Cu} \quad 38$

4.4 Effect of Varying K 42

4.5 Data Analysis by Regression 47

4.6 Characterization of the Catalyst 51

4.7 Summary 53

Chapter 5 Conclusions and Future Work 55

5.1 Conclusions $\quad 55$

5.2 Recommendations for Future Work 56

$\begin{array}{ll}\text { References } & 57\end{array}$

$\begin{array}{ll}\text { Appendix I } & 58\end{array}$

$\begin{array}{ll}\text { Appendix II } & 64\end{array}$

$\begin{array}{ll}\text { Appendix III } & 68\end{array}$

$\begin{array}{ll}\text { Appendix IV } & 71\end{array}$

$\begin{array}{ll}\text { Appendix V } & 75\end{array}$

$\begin{array}{ll}\text { Appendix VI } & 79\end{array}$

Appendix VII 86

$\begin{array}{ll}\text { Appendix VIII } & 89\end{array}$ 


\section{List of Tables}

Table 2.1: Relative Prices of Common FTS Catalysts Metals 4

Table 2.2: Degree of Reduction Using Different Gases 7

Table 2.3: BET Measurements of AC Supports and Catalysts 12

Table 2.4: Reaction Results for Catalyst of Differing Activated Carbon Supports 13

Table 3.1: Norit SX Ultra Properties Measured by BET 15

Table 3.2: Gas Cylinder Types 15

Table 3.3: Amount of Metal Salt Added per gram AC 23

Table 3.4: Catalyst Comparison Breakdown 23

Table 4.1: Mass Balance Error $\quad 29$

Table 4.2: Average CO Conversion between 24-48 Hours for Varying Mo Catalysts 31

Table 4.3: Average Gas Phase Component Selectivities for Varying Mo Composition 31

Table 4.4: Aqueous Product Amounts for Catalysts of Varying Mo 32

Table 4.5: Lumped Oil Product Distribution for Varied Mo Catalysts 33

Table 4.6: Liquid Product Properties for Catalysts of Varying Mo Composition 34

Table 4.7: Average CO Conversion between 24-48 Hours for Varying Fe Catalysts 35

Table 4.8: Average Gas Phase Component Selectivities for Varying Fe Composition 35

Table 4.9: Aqueous Product Amounts for Catalysts of Varying Fe 36

Table 4.10: Lumped Oil Product Distribution for Varied Fe Catalysts 37

Table 4.11: Liquid Product Properties for Catalysts of Varying Fe Composition 37

Table 4.12: Average CO Conversion between 24-48 Hours for Varying Cu Catalysts 38

Table 4.13: Average Gas Phase Component Selectivities for Varying Cu Composition 39

Table 4.14: Aqueous Product Amounts for Catalysts of Varying Cu 40

Table 4.15: Lumped Oil Product Distribution for Varied Cu Catalysts 41

Table 4.16: Liquid Product Properties for Catalysts of Varying Cu Composition 42

Table 4.17: Average CO Conversion between 24-48 Hours for Varying K Catalysts 43

Table 4.18: Average Gas Phase Component Selectivities for Varying K Composition 44

Table 4.19: Aqueous Product Amounts for Catalysts of Varying K 45

Table 4.20: Lumped Oil Product Distribution for Varied K Catalysts 46

Table 4.21: Liquid Product Properties for Catalysts of Varying K Composition 47 
Table 4.22: $\mathrm{R}^{2}$ Values for the Regression Models 50

Table 4.23: BET Properties for Base Case Catalyst 51

Table 4.24: $\mathrm{H}_{2}$ Consumption for Varying Fe Catalysts 54

Table 4.25: Degree of Reduction for Varying Fe Catalysts 54 


\section{List of Figures}

Figure 2.1: Example of the Weight Fraction as a Function of the Chain Growth Probability Factor as Calculated by the ASF Equation

Figure 3.1: Reactor Set-up 17

Figure 3.2: Schematic of the Catalyst Bed 18

Figure 3.3: Schematic of the Liquid Trap 19

Figure 4.1: CO Conversion Comparison for Iron Catalysts of 30 Varying Mo Composition

Figure 4.2: Alcohol Distribution for Catalysts of Varying Mo Content 32

Figure 4.3: Oil Fraction Selectivity for Varying Mo 33

Figure 4.4: CO Conversion Comparison for Iron Catalysts of 34 Varying Fe Composition

Figure 4.5: Alcohol Distribution for Catalysts of Varying Fe Content 36

Figure 4.6: Oil Fraction Selectivity for Varying Fe 37

Figure 4.7: CO Conversion Comparison for Iron Catalysts of 38

Varying Cu Composition

Figure 4.8: Alcohol Distribution for Catalysts of Varying Cu Content 40

Figure: 4.9: Oil Fraction Selectivity for Varying $\mathrm{Cu} \quad 41$

Figure 4.10: CO Conversion Comparison for Iron Catalysts of 43

Varying K Composition

Figure 4.11: Alcohol Distribution for Catalysts of Varying K Content 45

Figure 4.12: Oil Fraction Selectivity for Varying K 46

Figure 4.13: XRD Pattern for Base Case Catalyst Before Reaction 51

Figure 4.14: XRD Pattern for Base Case Catalyst after Reaction 52

Figure 4.15: TPR Data for Varied Fe Catalysts 53 


\section{Chapter 1}

\section{Introduction}

Fischer-Tropsch synthesis (FTS) is a catalytic process defined as "a hydrogenation of oxides of carbon producing much higher hydrocarbons or alcohols.”1 The main reactions pertinent to FTS are the hydrocarbon polymerization reaction

$$
\mathrm{nCO}+(2 \mathrm{n}+1) \mathrm{H}_{2} \rightarrow \mathrm{C}_{\mathrm{n}} \mathrm{H}_{(2 \mathrm{n}+2)}+\mathrm{nH}_{2} \mathrm{O}
$$

and the water gas shift reaction (WGS).

$$
\mathrm{CO}+\mathrm{H}_{2} \mathrm{O} \rightarrow \mathrm{CO}_{2}+\mathrm{H}_{2}
$$

In 1902, the first reports of heterogeneous CO hydrogenation on Ni catalysts yielding methane were made by scientists Sabatier and Senderens. BASF has patents from 1913 reporting the synthesis of liquid hydrocarbons using Co on Os catalysts. The products consisted of paraffins, olefins and oxygenates (i.e. alcohols, ethers). These studies led to the development of the first methanol synthesis plant that went on stream in $1923^{2}$

The Fischer-Tropsch process as known today was invented in the 1920s by German scientists Franz Fischer and Hans Tropsch. Their classic experiments date back to 1922, where they used high pressure and temperatures with alkalized iron catalysts to perform CO hydrogenation ${ }^{2}$.

Until 1945, FTS was carried out in 15 plants in countries such as Germany, France, Japan and China. After World War II, most of these plants were dismantled and those that were still operational had to be shut down for economic reasons ${ }^{2}$. Currently, the process is commercially used by a limited number of companies in few locations such as Sasol in South Africa and Shell in Malaysia. 
The largest implementation of FTS technology comes from Sasol. Sasol is a South African company with a series of plants along with a large stake in plants owned by other companies such as the Oryx Gas-to-Liquid (GTL) plant in Qatar. These plants produce gasoline and diesel from coal and natural gas. Sasol uses cobalt-based catalysts in their processes.

Rentech operates a demonstration-scale plant in the United States. The facility is designed to produce over 400 gallons per day of synthetic jet fuel, aviation fuel, diesel, and specialty waxes and chemicals. The plant can utilize biomass, coal, and natural gas for its feedstock. Rentech also has a number of full-scale plants in the design phase. The company uses iron-based catalysts.

A major challenge in the way of feasibility of large scale commercial FTS plants is economics. To be economic, the process needs a high selectivity to diesel and gasoline based on the syngas used, due to its cost accounting for roughly $80 \%$ of production costs ${ }^{3}$.

The purpose of this project was to develop a catalyst for FTS to produce a single battlefield fuel using materials obtainable in the United States, namely iron and activated carbon (AC). For this project, catalysts containing $\mathrm{Mo}, \mathrm{Fe}, \mathrm{Cu}$ and $\mathrm{K}$ on activated carbon supports were investigated. The catalyst composition that was used as a base case consisted of 6 wt $\%$ Mo, 16 wt\% Fe, 0.8 wt\% Cu and 0.9 wt\% K. A systematic approach was used to test the effectiveness of various catalyst compositions. The parameter of interest was the yield of total hydrocarbons in the range of $C_{9}$ to $C_{15}$, the gasoline/kerosene range. Oxygenates were also of interest.

The reaction conditions were not varied for this study and were $300^{\circ} \mathrm{C}, 300$ psig and $6 \mathrm{Nl} / \mathrm{gcat} / \mathrm{h}$. The syngas used had a ratio of $1.0\left(\mathrm{H}_{2} / \mathrm{CO}\right)$. The goal of this project was 
to study the effects of varying the four elemental composition variables. Parameters that were of interest include selectivity, activity and stability. 


\section{Chapter 2}

\section{Literature Review}

\subsection{Fischer-Tropsch Catalysts}

\subsubsection{Catalysts}

Group VIII metals are commonly used as Fischer-Tropsch catalysts. The activity of the Group VIII metals were determined and reported as Ru, Fe, Co, Rh, Pd, Pt, and Ir in order of decreasing activity ${ }^{4}$. Iron is often used due to its low cost. Table 2.1 shows a relative comparison in cost of some commonly used FTS catalysts.

\begin{tabular}{|c|c|}
\hline Table 2.1: Relative Prices of Common FTS Catalyst metals \\
\hline Metal & Price Ratio (circa 1989) \\
\hline Iron & 1 \\
\hline Cobalt & 230 \\
\hline Nickel & 250 \\
\hline Ruthenium & 31,000 \\
\hline Rhodium & 570,000 \\
\hline
\end{tabular}

In addition to the low cost, the advantages of iron catalysts are high activity for FTS and $\mathrm{WGS}^{5}$. Iron catalysts have a high selectivity toward olefins ${ }^{3}$. Undesirable effects of iron catalysts include oxidation, carburization of the reduced metal or deposition of elemental carbon $^{6}$. Oxidation results in a loss of active surface area as iron oxides are inactive for FTS $^{7}$. Catalysts particle swelling can be caused by elemental carbon deposition which could result in the plugging of fixed bed reactors ${ }^{7}$.

Cobalt catalysts are viable for producing middle distillate (kerosene, diesel) FTS products using natural gas as the feedstock. When converting natural gas to syngas, a $\mathrm{H}_{2}$ :CO ratio of $2+$ is $\operatorname{seen}^{8}$. This works well for cobalt catalysts because of their low WGS activity ${ }^{8}$. Because there is an abundance of $\mathrm{H}_{2}$ already in the feedstock, WGS is not 
needed to produce $\mathrm{H}_{2}$ for the reaction. The products from a cobalt-catalyzed FTS are generally saturated long-chain hydrocarbons or higher linear alcohols ${ }^{9}$.

$\mathrm{Ni}$, Rh and Ru are not very viable choices for FTS. Ni has a very high selectivity toward methane while Ru and Rh are very expensive and not widely available ${ }^{5}$.

\subsubsection{Promoters}

The addition of promoters to Co and Ru catalysts does not affect the efficiency very much. With Co, the addition of thorium and alkali promoters increases the wax production, and supports are used to increase the surface area of the active metal. In contrast, promoters are essential for iron catalysts ${ }^{2}$.

Mo has been shown ${ }^{10}$ to increase Fe catalyst stability in small amounts (6\%); however, in large amounts (12\%), it decreases the yield of higher numbered hydrocarbons.

Copper has been shown ${ }^{11}$ to promote the FTS reaction in Fe catalysts. The reaction rate increases with the addition of a small amount $(0-2 \%)$ of $\mathrm{Cu}^{11}$. It also increases the rate of the WGS, but not the $\mathrm{CO}_{2}$ selectivity ${ }^{11}$. Methane selectivity decreases while heavier product selectivity increases with the amount of $\mathrm{Cu}^{11}$. Cu does not have any effect on alkene selectivity ${ }^{11}$. The addition of $\mathrm{Cu}$ also leads to an increased rate of reduction, thereby allowing it to be carried out at lower temperatures ${ }^{2}$.

The hydrogenation activity of iron catalysts is largely influenced by the addition of “electronic promoters” such as alkali metals. Their efficiency depends on the basicity and the following order is found: $\mathrm{Rb}, \mathrm{K}, \mathrm{Na}$, and $\mathrm{Li}$, from best to worst $^{2}$. With the addition of electronic promoters, an increase in activity and an enhanced selectivity toward CO-consuming reactions is seen ${ }^{2}$. This means that the average molecular weight 
of the products is increased, methane formation is decreased, olefin formation is increased, and oxygenated product formation is increased ${ }^{2}$. Small amounts of potassium have been shown ${ }^{12}$ to increase catalytic activity while increasing potassium decreases activity and increases the deactivation rate of the catalyst.

Alkaline promoters lead to a decrease in the active surface area of iron catalysts. Structural promoters are added in order to compensate for this effect. These consist of nonreducible metal oxides such as $\mathrm{Al}_{2} \mathrm{O}_{3}$ and $\mathrm{Cr}_{2} \mathrm{O}_{3}$. These give high surface areas, but slow the rate of reduction ${ }^{2}$.

\subsubsection{Catalyst Pretreatment}

In order to become active for FTS, catalysts must be activated through a pretreatment process. When iron oxides are activated under hydrogen, they form metallic iron $^{13}$. This is subsequently converted to iron carbides when syngas is introduced ${ }^{13}$. The active phase for iron is thought to be iron carbides ${ }^{14}$. Pretreatment of Fe catalysts is not as simple as it is in cobalt catalysts where the active phase is thought to be Co metal.

Table 2.2 shows the change in the degree of reduction of an iron catalyst with different gases. The reduction conditions were $673 \mathrm{~K}$ at 8 hours with a fixed space velocity. When CO is used in the reduction gas, the degree of reduction is much less than that of a catalyst reduced by only $\mathrm{H}_{2}$. However, iron carbides are only present in catalysts reduced with CO. Studies done by Luo and Davis ${ }^{14}$ indicate that the highest conversions (60-80\%) are obtained by CO-activated catalysts while the lowest conversions (40-60\%) are from $\mathrm{H}_{2}$-activated catalysts. This is consistent with iron carbides being the active phase for Fe-based FT catalysts. 


\begin{tabular}{|c|c|c|}
\hline \multicolumn{3}{|c|}{ Table 2.2: Degree of Reduction Using Different Gases } \\
\hline Gas & Reduction (\%) & Phases Present \\
\hline $100 \% \mathrm{H}_{2}$ & 80 & $\alpha-\mathrm{Fe}, \mathrm{Fe}_{3} \mathrm{O}_{4}$ \\
\hline $98 \% \mathrm{H}_{2}+2 \% \mathrm{CO}$ & 20 & $\mathrm{Fe}_{5} \mathrm{C}, \mathrm{Fe}_{3} \mathrm{O}_{4}$ \\
\hline $100 \% \mathrm{CO}$ & 4 & $\mathrm{Fe}_{5} \mathrm{C}, \mathrm{Fe}_{3} \mathrm{O}_{4}$ \\
\hline
\end{tabular}

\subsubsection{Catalyst Poisoning}

There are two types of poisoning: reversible and irreversible. Reversible poisoning is caused by compounds containing oxygen such as $\mathrm{O}_{2}$, $\mathrm{CO}$, and $\mathrm{H}_{2} \mathrm{O}$, while irreversible poisoning is attributed to non-metals such as sulfur, chlorine and phosphorus $^{15}$.

Iron, cobalt, and nickel catalysts are rapidly deactivated by all sulfur-containing compounds $^{2}$. It has been explained ${ }^{2}$ that sulfur deactivates the catalyst by withdrawing electrons from the catalyst surface. This is said ${ }^{16}$ to be due to the suppression of electron back-bonding. Sulfur has also been shown ${ }^{2}$ to inhibit the dissociation of CO. Fortunately, the efficiency of modern-day gas purification systems can reduce the sulfur level in syngas to tolerable levels ${ }^{2}$, below $0.03 \mathrm{mg} / \mathrm{m}^{3}$.

Iron catalysts which have been poisoned by sulfur cannot be readily reactivated. Only very thorough reoxidation, where all traces of sulfur are burnt away, followed by reduction, is effective ${ }^{2}$.

Chloride and bromide ions are also known to deactivate iron catalysts ${ }^{2}$. There are two mechanisms suggested for chlorine poisoning of iron catalysts ${ }^{15}$. One involves the formation of iron-chlorine compounds which could increase the size of the iron crystallites $^{15}$. As a result, the active surface area of the catalyst will decrease. The other possible mechanism has the chlorine interacting with potassium, an important promoter in iron catalysts, forming $\mathrm{KCl}^{15}$. The $\mathrm{KCl}$ could diffuse into the catalyst grain or diffuse 
into the gas stream, causing an irreversible loss of potassium ${ }^{15}$ and consequent loss of activity.

\subsection{Selectivity}

The products from FTS can vary with varying operating conditions and with the type of catalyst used. Anderson ${ }^{1}$ describes some pertinent characteristics of the FTS products, based mostly on data from cobalt and iron catalysts:

1. Water is a primary product due to WGS. Primary alcohols and $\alpha$-olefins may also be primary products.

2. The carbon number distribution on a molar basis is large for $C_{1}$, then drops for $C_{2}$, increases to a local maximum for either $\mathrm{C}_{3}$ or $\mathrm{C}_{4}$, and then decreases monotonically.

3. Monomethyl-substituted hydrocarbons are present in moderate amounts.

4. Dimethyl species are present in significantly smaller amounts than monomethyl species. Ethyl-substituted species are found in similar amounts to dimethyl species.

5. Using iron catalysts, naphthenes and aromatics are produced in small amounts in fixed-bed reactors, while moderate amounts are found in fluidized reactors. None of these products are usually produced with a cobalt catalyst.

6. Olefins produced from iron catalysts are often found in amounts exceeding $50 \%$ of each carbon number, and more than $60 \%$ of these are $\alpha$-olefins. These fractions are independent of carbon number. With a cobalt catalyst, these fractions are smaller and decrease with increasing carbon number. 
7. Alcohol yields are a maximum at $C_{2}$ and decrease monotonically with higher carbon number.

\subsubsection{The Anderson-Schulz-Flory Distribution}

The Anderson-Schulz-Flory (ASF) distribution gives the chain length distribution if the hydrocarbon chain is formed step-wise by insertion or addition of $\mathrm{C}_{1}$ intermediates with a constant chain growth probability $(\alpha)^{17}$, which is the probability that a molecule will continue reacting to form a longer chain rather than begin a new chain. The ASF equation is as follows:

$$
\log \left(\frac{W_{n}}{n}\right)=n \log \alpha+\log \left(\ln ^{2} \alpha\right)
$$

where $W_{n}$ is the mass fraction of the species with carbon number $n$. This means that $W_{n} / n$ can be plotted in semi-log coordinates against $\mathrm{n}$ to yield a straight line whose slope is $\log \alpha$

Figure 2.1 shows the weight fraction as a function of the chain growth probability for varying $n$ as calculated with Equation 2.1: 


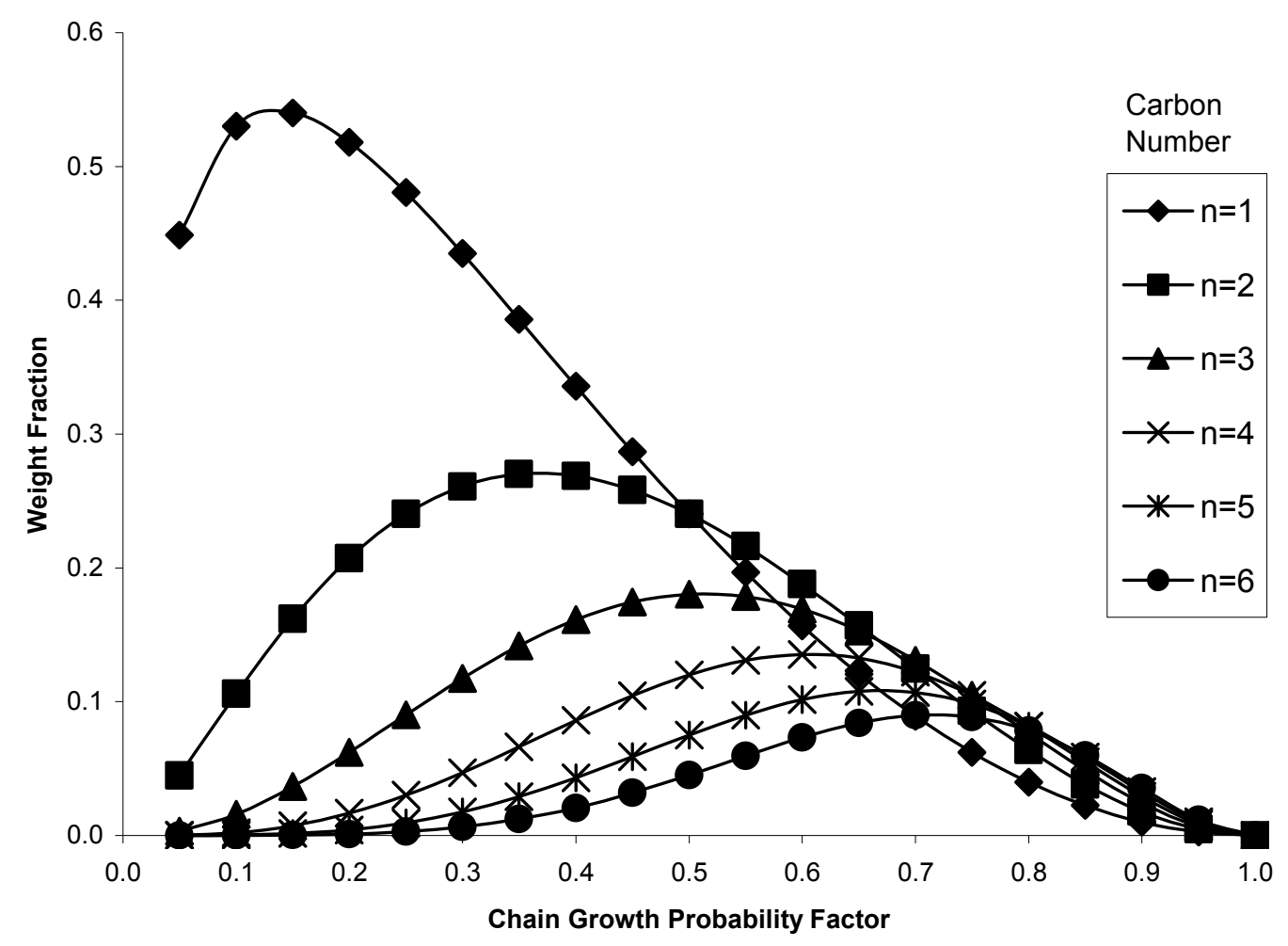

Figure 2.1: Example of the Weight Fraction as a Function of the Chain Growth Probability Factor as Calculated by the ASF Equation

\subsubsection{Deviations from the ASF Distribution}

In most cases deviations from the ideal ASF distribution occur. The majority of reported ASF diagrams show a straight line only between $\mathrm{C}_{4}-\mathrm{C}_{12}$. Methane tends to be more than predicted for Co and Ru catalysts. This is attributed to methyl groups being cleaved from 1-olefins. The $\mathrm{C}_{2}$ and $\mathrm{C}_{3}$ products are much less than predicted for $\mathrm{Co}$ and Ru catalysts, while only slightly less than predicted for Fe catalysts. This is thought to be because the ethane and propane are being incorporated into an olefin and initializing a new chain ${ }^{18}$.

The "two-site model" was developed by Koenig and Gaube ${ }^{19}$ for cases when a curved ASF diagram is obtained. This has happened in the case of an alkali-promoted 
iron catalyst. It was hypothesized that the alkalization creates a second catalytic site. In these cases, the product distribution can be estimated by the superposition of two ASF diagrams, and two $\alpha$ values are obtained. A second, equivalent method was developed later by Stenger ${ }^{20}$ and called the "distributed site model". The assumption of this model is that the two sites are distributed randomly throughout the catalyst with concentration values between 0 and a maximum ${ }^{18}$.

Puskas and Hurlbut ${ }^{18}$ have reported that the ASF equations are fundamentally correct. Deviations from the ASF equations can be justified with kinetic considerations and accounting for secondary reactions.

\subsection{Related WVU Laboratory Work}

Recently, $\mathrm{Ma}^{10,12,21,22}$ worked extensively on this subject. In particular, the effect of activated carbon support source ${ }^{21}$, Mo loading ${ }^{10}, \mathrm{~K}$ loading ${ }^{18}$, and $\mathrm{Cu}$ loading ${ }^{22}$ were investigated.

There has been a growing interest in AC as a catalyst support in recent years ${ }^{21}$. This is partially due to its low cost, unique texture and surface properties. The physical texture of AC has been reported to impact the reduction and dispersion of active metals on the support surface, especially when using the incipient-wetness impregnation technique. In addition, AC has been found to be a promising choice for restricting hydrocarbon chain length ${ }^{21}$. Studies involving iron, cobalt and molybdenum-nickel catalysts indicate that chain length could be limited to less than $\mathrm{C}_{35}$ on $\mathrm{AC}^{21}$.

$\mathrm{Ma}^{21}$ investigated four different sources for the activated carbon support: peat, pecan, walnut, and a generic wood source. Table 2.3 summarizes the physical properties of the investigated sources in both unimpregnated and impregnated forms. 


\begin{tabular}{|c|c|c|c|c|c|c|c|}
\hline \multicolumn{7}{|c|}{ Table 2.3: BET Measurements of AC Supports and Catalysts } \\
\hline $\begin{array}{c}\text { Supports } \\
\text { and } \\
\text { Catalysts }\end{array}$ & $\begin{array}{c}\text { Total } \\
\text { SA } \\
\left(\mathrm{m}^{2} / \mathrm{g}\right)\end{array}$ & $\begin{array}{c}\text { Mircopore } \\
\text { SA }\left(\mathrm{m}^{2} / \mathrm{g}\right)\end{array}$ & $\begin{array}{c}\text { Total } \\
\text { PV } \\
\left(\mathrm{cm}^{3} / \mathrm{g}\right)\end{array}$ & $\begin{array}{c}\text { Micropore } \\
\text { volume } \\
\left(\mathrm{cm}^{3} / \mathrm{g}\right)\end{array}$ & $\begin{array}{c}\text { Mean } \\
\text { Pore } \\
\text { Size } \\
(\mathrm{nm})\end{array}$ & $\begin{array}{c}\text { Percentage } \\
\text { of } \\
\text { Micropores } \\
(\mathrm{SA})\end{array}$ & $\begin{array}{c}\text { Percentage } \\
\text { of } \\
\text { Micropores } \\
(\mathrm{PV})\end{array}$ \\
\hline $\begin{array}{c}\text { Peat } \\
\text { Support }\end{array}$ & 606 & 151 & 0.48 & 0.255 & 5.9 & 25 & 53 \\
\hline $\begin{array}{c}\text { Wood } \\
\text { Support }\end{array}$ & 970 & 56 & 0.58 & 0.138 & 6.6 & 6 & 25 \\
\hline $\begin{array}{c}\text { Pecan } \\
\text { Support }\end{array}$ & 1016 & 280 & 0.72 & 0.358 & 5.1 & 28 & 50 \\
\hline $\begin{array}{c}\text { Walnut } \\
\text { Support }\end{array}$ & 892 & 233 & 0.50 & 0.182 & 3.9 & 26 & 37 \\
\hline $\begin{array}{c}\text { Peat } \\
\text { Catalyst }\end{array}$ & 347 & 104 & 0.25 & 0.131 & 4.1 & 30 & 25 \\
\hline $\begin{array}{c}\text { Wood } \\
\text { Catalyst }\end{array}$ & 534 & 52 & 0.32 & 0.084 & 5.4 & 10 & 38 \\
\hline $\begin{array}{c}\text { Pecan } \\
\text { Catalyst }\end{array}$ & 499 & 89 & 0.32 & 0.122 & 4.0 & 18 & 28 \\
\hline $\begin{array}{c}\text { Walnut } \\
\text { Catalyst }\end{array}$ & 476 & 54 & 0.29 & 0.081 & 3.7 & 11 & \\
\hline
\end{tabular}

The highest value for the BET total surface area belongs to the pecan-based AC support, and the peat-based has the lowest value. The pecan-based, walnut-based and peat-based AC supports have wide pores contributing $25-28 \%$ of the surface area while the wood-based only has $6 \%$ of the surface in wide pores. This suggests that all four supports are highly microporous.

Once impregnated with the metals, both total surface area and total pore volume decrease by nearly the same amount. When taking only the wide pores into consideration, the pecan-based and walnut-based catalysts have the largest decrease in surface area ( $73 \%$ ), the peat-based catalyst has a significantly smaller decrease (31\%), while the wood-based catalyst has the smallest decrease $(\sim 9 \%)$. The same trend is seen in pore volume, with a $61 \%$ decrease in the pecan-based and walnut-based catalysts, a $49 \%$ decrease in the peat-based catalyst, and a 39\% decrease in the wood-based catalyst. 
Table 2.4 contains information on the reaction studies with the four ACs.

\begin{tabular}{|c|c|c|c|c|}
\hline \multicolumn{2}{|c|}{ Table 2.4:Reaction Results for Catalysts of Differing Activated Carbon Supports } \\
\hline \multirow{2}{*}{ AC Support } & CO Conversion & \multicolumn{3}{|c|}{ Selectivity (wt \%) } \\
\cline { 3 - 5 } & $(\%)$ & $\mathrm{C}_{1}$ & $\mathrm{C}_{2}-\mathrm{C}_{4}$ & $\mathrm{C}_{5+}$ \\
\hline Peat & 87.1 & 10.9 & 40.9 & 48.2 \\
\hline Wood & 37.9 & 13.9 & 54.8 & 31.3 \\
\hline Pecan & 90.1 & 15.3 & 32.4 & 52.3 \\
\hline Walnut & 58.5 & 14.9 & 34.6 & 50.5 \\
\hline
\end{tabular}

Catalysts with pecan- and peat-based AC supports have the highest CO conversion, while the wood-based catalysts have the lowest. The catalysts with the pecan-, walnut- and peat-based AC supports have the highest selectivity toward $\mathrm{C}_{5+}$ while the wood-based catalyst has a high selectivity toward $\mathrm{C}_{2}-\mathrm{C}_{4}$.

In investigating the effects of Mo loading, $\mathrm{Ma}^{10}$ made catalysts containing 0,6 and $12 \mathrm{wt} \% \mathrm{Mo}$ in addition to $15.7 \% \mathrm{Fe}, 0.8 \% \mathrm{Cu}$, and $0.9 \% \mathrm{~K}$. For the catalyst without Mo, the initial CO conversion is nearly $100 \%$; however, the catalyst rapidly deactivates and the reaction was stopped after 72 hours. For the catalyst containing 6\% Mo, the opposite effect is seen. The initial conversion is seen to be $60 \%$, and it increases rapidly to $90 \%$ during the first 72 hours and remains stable for an additional 72 hours. In the case of the $12 \%$ Mo catalyst, the conversion starts out at $60 \%$, the same as the $6 \%$ loading, but it then slowly decreases to $53 \%$ over a 143 -hour period.

The percentage loading of Mo also changes the product distribution. Mo increases the amount of methane and inhibits the formation of higher molecular weight species. The selectivity of oxygenates is very low for all three loading percentages, but increases somewhat with loading.

$\mathrm{Ma}^{12}$ also looked at the effects of potassium loading. For this, the catalysts prepared did not contain any other promoter. The amount of Fe used in all the catalysts 
was $15.7 \%$ and potassium was used in the amounts of $0,0.9$ and $2 \%$. In this study, the effect of temperature was also studied from $260-300^{\circ} \mathrm{C}$, in $10^{\circ} \mathrm{C}$ increments. Briefly, the results of the study show that small amounts of potassium increase FTS activity while larger amounts hinder activity, and the potassium reduces catalyst stability. The potassium has a significantly larger effect on the extent of WGS than on FTS. At lower temperatures, the selectivity of $\mathrm{C}_{1}-\mathrm{C}_{4}$ products decreases while $\mathrm{C}_{5+}$ products increase with the addition of $\mathrm{K}$. As the temperature is increased, the selectivity toward lower carbon numbers increases.

The effect of $\mathrm{Cu}$ loading was studied by $\mathrm{Ma}^{22}$. These catalysts did not contain Mo. The amount of Fe used in all catalysts was $15.7 \%$ and the amount of $\mathrm{K}$ was $0.9 \%$. The amount of $\mathrm{Cu}$ used was $0,0.8$ and 2\%. The effect of temperature were studied from 260$290^{\circ} \mathrm{C}$. The addition of $\mathrm{Cu}$ significantly decreases reduction temperature and increases reduction rate. The addition of $0.8 \% \mathrm{Cu}$ causes a decrease in both FTS and WGS activity; however, with the addition of $2 \% \mathrm{Cu}$, this change is lessened. The addition of $\mathrm{Cu}$ does not significantly change the overall hydrocarbon distribution. The addition of $\mathrm{Cu}$ leads to an increase in oxygenate selectivity. 


\section{Chapter 3}

\section{Experimental Equipment and Procedure}

\subsection{Materials}

The activated carbon used for the catalyst support in this project is Norit SX Ultra procured from Sigma Aldrich. This AC was chosen due to its high surface area and pore volume, in addition to its recommendation by Norit for catalyst applications. Table 3.1 includes information on the AC obtained through BET analysis completed in the lab.

\begin{tabular}{|c|c|c|c|}
\hline \multicolumn{5}{|c|}{ Table 3.1: Norit SX Ultra Properties Measured by BET } \\
\hline $\begin{array}{c}\text { BET Surface } \\
\text { Area }\left(\mathrm{m}^{2} / \mathrm{g}\right)\end{array}$ & $\begin{array}{c}\text { Large-Pore Surface } \\
\text { Area }\left(\mathrm{m}^{2} / \mathrm{g}\right)\end{array}$ & $\begin{array}{c}\text { Micropore Volume } \\
<2.0 \mathrm{~nm}\left(\mathrm{~cm}^{3} / \mathrm{g}\right)\end{array}$ & $\begin{array}{c}\text { Macropore Volume } \\
>2.0 \mathrm{~nm}\left(\mathrm{~cm}^{3} / \mathrm{g}\right)\end{array}$ \\
\hline 951 & 387 & 0.26 & 0.63 \\
\hline
\end{tabular}

For the catalyst impregnation, the sources of $\mathrm{Mo}, \mathrm{Fe}, \mathrm{Cu}$ and $\mathrm{K}$ metals were $\left(\mathrm{NH}_{4}\right)_{6} \mathrm{Mo}_{7} \mathrm{O}_{24} \cdot 4 \mathrm{H}_{2} \mathrm{O}, \mathrm{Fe}\left(\mathrm{NO}_{3}\right)_{3} \cdot 9 \mathrm{H}_{2} \mathrm{O}, \mathrm{Cu}\left(\mathrm{NO}_{3}\right)_{2} \cdot 2.5 \mathrm{H}_{2} \mathrm{O}$ and $\mathrm{KNO}_{3}$ respectively. All these chemicals were acquired from Sigma Aldrich. Section 3.3.1 contains the catalyst preparation procedure.

The gas cylinders that were used in the reactor system and the gas chromatographs were all purchased from Airgas. The description for the gas cylinders is included in Table 3.2.

\begin{tabular}{|l|r|}
\hline \multicolumn{2}{|c|}{ Table 3.2: Gas Cylinder Types } \\
\hline \multicolumn{1}{|c|}{ Gas } & Purity \\
\hline Syngas* & N/A \\
\hline Air & Breathing Quality \\
\hline Nitrogen & Ultra High \\
\hline Helium & Ultra High \\
\hline Hydrogen & Ultra High \\
\hline
\end{tabular}

*A mixture of $45 \% \mathrm{H}_{2}, 45 \% \mathrm{CO}, 5 \% \mathrm{He}$ and $5 \% \mathrm{Ar}$ 


\subsection{Equipment}

\subsubsection{Reactor System}

A schematic of the reactor system is shown in Figure 3.1. There are three gas cylinders connected to the reactor system: helium, hydrogen and syngas $\left(45 \% \mathrm{H}_{2}, 45 \% \mathrm{CO}\right.$, 5\%He, 5\%Ar). These gases are fed into separate mass flow controllers (MFCs) controlled by the computer. After the MFCs, the streams converge and enter the reactor. The reactor is a simple fixed-bed stainless-steel tube jacketed in a furnace. The furnace is regulated by the computer in the same program as the MFCs. Thermocouples are placed into the top of the reactor as well as on the outside of the reactor to record the temperature of the system. Figure 3.2 shows the catalyst bed in more detail. The procedure for loading the reactor is given later.

After the reactor, there is a liquid trap. This is shown in more detail in Figure 3.3. For this, a dip-leg is used to take the reactor effluent to the bottom of the trap. The liquid collects here, while the gas is free to flow around the dip-leg to a side stream that goes to the gas chromatograph (GC) and the vent. The valve at the bottom of the liquid trap is used to drain the liquid product for collection. The liquid trap is wrapped in copper tubing which has cooling water pumped through it. It was kept at a temperature between $5-10^{\circ} \mathrm{C}$.

The reactor temperature and flowrate are controlled by a computer system running the program Wonderware. The pressure of the system is controlled through a back-pressure regulator. 


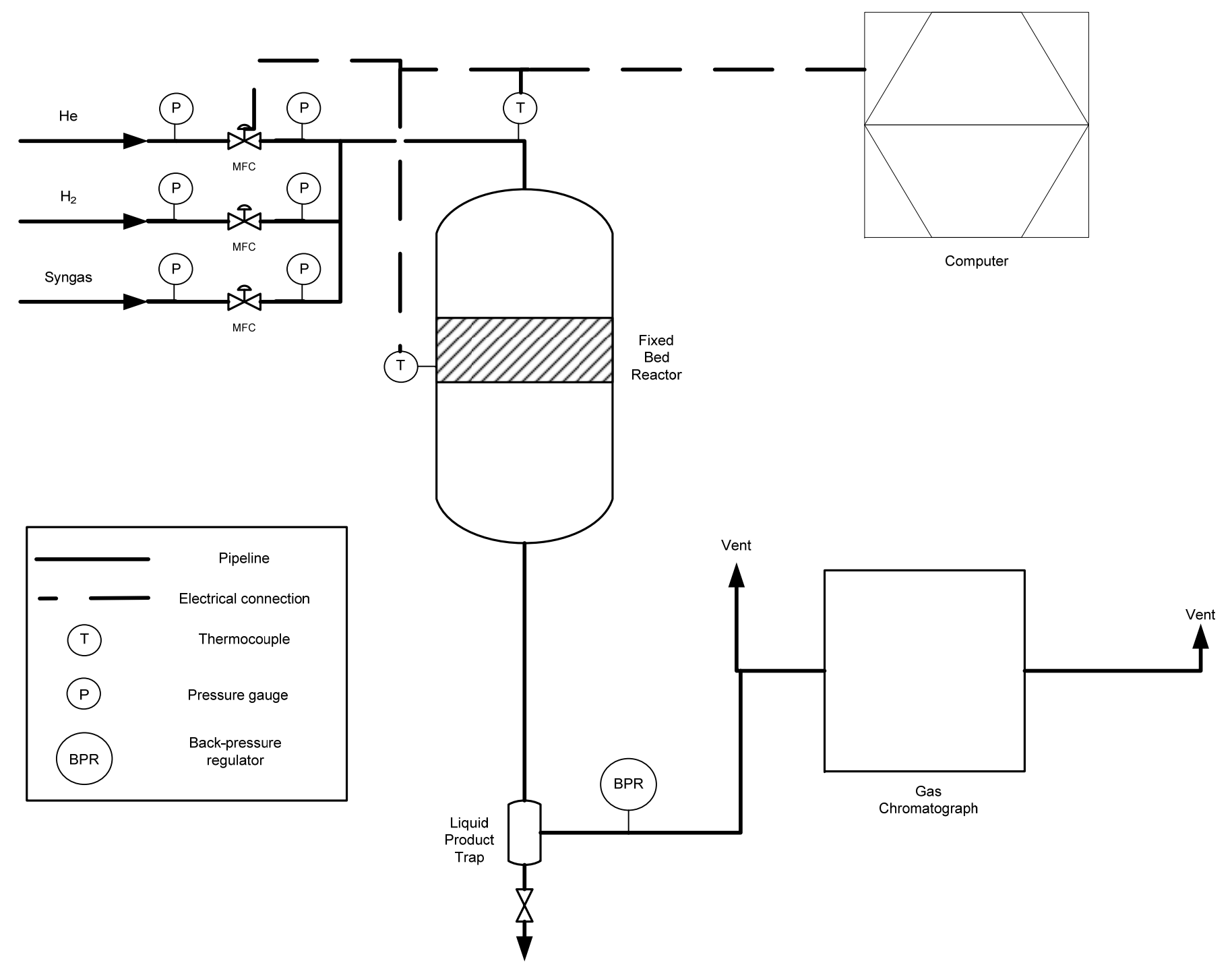

Figure 3.1: Reactor Set-up 


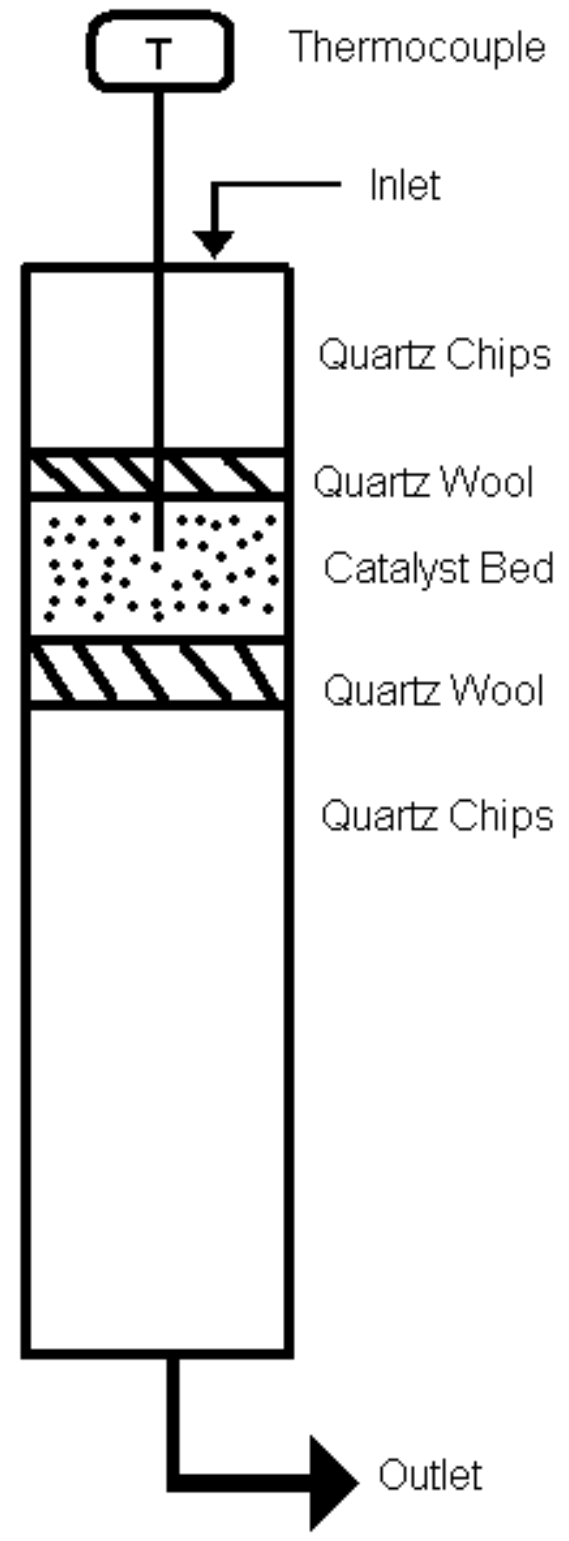

Figure 3.2: Schematic of the Catalyst Bed 


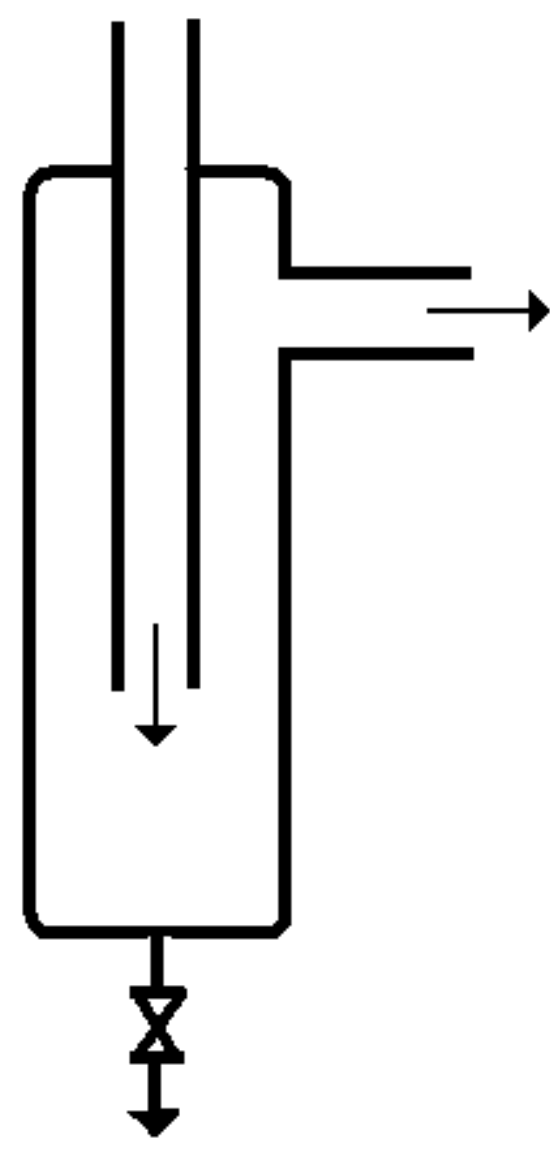

Figure 3.3: Schematic of the Liquid Trap

\subsubsection{Analysis of Reactor Outlet}

Analysis of the gas product is handled by a Clarus 500 Gas Chromatograph (GC) from Arnel, Inc. The GC uses a dual Thermal Conductivity Detector (TCD) and a Flame Ionization Detector (FID). The TCD notes difference in thermal conductivity between the carrier gas and the reactor effluent. The reason that a dual TCD is essential is due to the need to analyze for $\mathrm{H}_{2}$. The most common and sensitive inert carrier gas for the TCD is He; however, the thermal conductivities of $\mathrm{He}$ and $\mathrm{H}_{2}$ are nearly identical, so $\mathrm{H}_{2}$ cannot 
be detected using He as a carrier gas. To detect $\mathrm{H}_{2}$, a second TCD is utilized that employs $\mathrm{N}_{2}$ as the carrier gas.

The FID is most efficient for analyzing organic compounds such as hydrocarbons, and uses hydrogen and air to light a flame. The temperature of this flame is able to pyrolyze most organic compounds, producing positive ions and electrons. These ions are detected by two electrodes, creating a potential difference that allows the organics to be detected.

Analysis of the liquid product is handled by a Varian 3400 GC. This GC is equipped with two FIDs. The FIDs are on two separate analytical columns. The two columns are used separately to analyze the two liquid phases, oil and aqueous, independently on separate FID channels. The oil phase is analyzed using an MXT 2887 capillary column with a $10 \mathrm{~m}$ length, $0.53 \mathrm{~mm}$ inner diameter and a $2.65 \mu \mathrm{m}$ film thickness. The aqueous phase is analyzed using a TXTA packed column that is $2 \mathrm{~m}$ long and has a $2 \mathrm{~mm}$ inner diameter.

\subsubsection{Catalyst Characterization}

The catalysts were characterized both pre- and post-reaction by Brunauer-EmmetTeller (BET) surface area, X-ray diffraction (XRD), temperature-programmed reduction (TPR), CO chemisorption and energy-dispersive $\mathrm{X}$-ray spectroscopy (EDS).

The BET technique uses liquid nitrogen to measure the adsorption of AC samples. From this, a series of equations in BET theory can be used to calculate the surface area. BET Theory is an extension of a monolayer molecular adsorption model, Langmuir theory, to a multilayer model. The equation used to determine the total surface area of the sample is: 


$$
S_{\text {TOTAL }}=\frac{v_{m} N s}{V}
$$

where $\mathrm{S}_{\text {TOTAL }}$ is the total surface area, $\mathrm{v}_{\mathrm{m}}$ is the volume of $\mathrm{N}_{2}$ adsorbed in a monolayer, $\mathrm{N}$ is Avogadro's number, $\mathrm{s}$ is the adsorption cross-section (the amount that can be adsorbed into a cross-section), and $\mathrm{V}$ is the molar volume of the adsorbed species. A specific surface area (units of area/mass) can also be found using

$$
S=\frac{S_{\text {TОТАL }}}{a}
$$

where a is the mass of the absorbent. Surface area and pore volume measurements were made with a Micromeritics ASAP 2020.

XRD uses X-ray diffraction to find the crystalline structure and physical properties of materials. The scattering intensity of an X-ray beam is measured as a function of incident and scattered angles, polarization and wavelength. Crystals exhibit a unique diffraction pattern; with a mixture of crystals, the patterns appear independently of each other. These patterns can be used to identify the samples. This will give an idea of the phase of the metals in the catalyst (i.e. Fe metal, $\mathrm{FeO}$, or $\mathrm{Fe}_{3} \mathrm{O}_{4}$ ). X-ray diffraction measurements were made using a PANalyticial X'Pert PRO.

TPR is used to find the degree of reduction of the catalyst. A U-tube is filled with catalyst, and the air is removed using flowing inert gas. Hydrogen is added by mass flow controllers and a temperature program is initiated. The exit gas is analyzed by the appropriate detectors. When reduction takes place, hydrogen is consumed by the reaction and the change in hydrogen content of the exit stream is picked up by the detectors. Using the amount of hydrogen consumed, the degree of reduction $\left(\mathrm{DR}_{\mathrm{T}}\right)$ can be calculated: 


$$
\mathrm{DR}_{\mathrm{T}}=\left(\frac{\text { Experimental } \mathrm{H}_{2} \text { Consumed }}{\text { Theorectical } \mathrm{H}_{2} \text { Required }}\right) \bullet 100
$$

EDS is used for elemental characterization of a sample. The sample is hit with an electron beam and releases X-rays in response. This is called X-ray florescence. Each element emits X-rays at characteristic energies which can be used to identify the elements present. The intensity of the florescence peaks can be used to discern the relative amounts of the elements present. The EDS being used is connected to a Hitachi S-4700 scanning electron microscope and is manufactured by EDAX/Ametek.

\subsection{Experimental Procedure}

\subsubsection{Catalyst Synthesis}

Activated carbon (AC) from Sigma-Aldrich was used as the catalyst support. The AC was washed by boiling it in deionized water, and the AC is dried. The first metal salt is then dissolved in water and added dropwise to the AC to incipient wetness. The order in which the salts were added to the carbon was as follows: $\mathrm{Mo}, \mathrm{Fe}, \mathrm{Cu}$, and $\mathrm{K}$. This is in the order of highest to lowest molecular weight of the compounds being used and was used by $\mathrm{Ma}^{10,12}$. The amount of each metal salt used is shown in Table 3.3. After a salt was added to the AC, it was dried overnight in air at a temperature between $90^{\circ} \mathrm{C}$ and $100^{\circ} \mathrm{C}$. Then the next salt could be added.

The base case composition is $6 \mathrm{wt} \% \mathrm{Mo}, 16 \mathrm{wt} \% \mathrm{Fe}, 0.8 \mathrm{wt} \% \mathrm{Cu}$ and $0.9 \mathrm{wt} \% \mathrm{~K}$. This composition is based on recent work done at $\mathrm{WVU}^{10,12}$. Table 3.4 shows the composition of all catalysts produced and studied. Sample 1 is the base case catalyst, Samples 2-4 are variation in Mo, Samples 5-7 are variations in Fe, Samples 8-10 are variations in $\mathrm{Cu}$ and Samples 11-13 are variations in $\mathrm{K}$. 


\begin{tabular}{|c|c|c|}
\hline \multicolumn{3}{|c|}{ Table 3.3: Amount of Metal Salt Added per gram AC } \\
\hline Promoter & Composition (\% Metal) & Amount of Salt (g/gAC) \\
\hline \multirow{4}{*}{ Mo } & 0.0 & 0.000 \\
\cline { 2 - 3 } & 3.0 & 0.056 \\
\cline { 2 - 3 } & 6.0 & 0.111 \\
\cline { 2 - 3 } & 12.0 & 0.222 \\
\hline \multirow{4}{*}{ Fe } & 0.0 & 0.000 \\
\cline { 2 - 3 } & 8.0 & 0.579 \\
\cline { 2 - 3 } & 16.0 & 1.157 \\
\hline \multirow{4}{*}{ Cu } & 32.0 & 2.314 \\
\cline { 2 - 3 } & 0.0 & 0.000 \\
\cline { 2 - 3 } & 0.4 & 0.015 \\
\cline { 2 - 3 } & 0.8 & 0.029 \\
\hline \multirow{4}{*}{$\mathrm{K}$} & 1.6 & 0.058 \\
\cline { 2 - 3 } & 0.0 & 0.000 \\
\cline { 2 - 3 } & 0.45 & 0.024 \\
\cline { 2 - 3 } & 0.9 & 0.047 \\
\hline
\end{tabular}

\begin{tabular}{|r|r|r|r|r|}
\hline \multicolumn{6}{|c|}{ Table 3.4 Catalyst Composition Breakdown } \\
\hline \multicolumn{1}{|c|}{ Sample } & \multicolumn{1}{|c|}{ Momponent Percentage } \\
\hline 1 & 6.0 & 16.0 & 0.8 & \multicolumn{1}{c|}{ Cu } \\
\hline 2 & 0.0 & 16.0 & 0.8 & 0.9 \\
\hline 3 & 3.0 & 16.0 & 0.8 & 0.9 \\
\hline 4 & 12.0 & 16.0 & 0.8 & 0.9 \\
\hline 5 & 6.0 & 0.0 & 0.8 & 0.9 \\
\hline 6 & 6.0 & 8.0 & 0.8 & 0.9 \\
\hline 7 & 6.0 & 32.0 & 0.8 & 0.9 \\
\hline 8 & 6.0 & 16.0 & 0.0 & 0.9 \\
\hline 9 & 6.0 & 16.0 & 0.4 & 0.9 \\
\hline 10 & 6.0 & 16.0 & 1.6 & 0.9 \\
\hline 11 & 6.0 & 16.0 & 0.8 & 0.0 \\
\hline 12 & 6.0 & 16.0 & 0.8 & 0.45 \\
\hline 13 & 6.0 & 16.0 & 0.8 & 1.8 \\
\hline
\end{tabular}

\subsubsection{Reactor Procedure}

Before loading the reactor, the position of the thermocouple in the reactor is measured and marked. Then $\sim 1 / 16$ " quartz chips are added to the reactor, to guarantee that the thermocouple is in the catalyst bed. The catalyst/diluent mixture is added next. 
This contains one gram of catalyst and four grams of 1/32" quartz chips, the same size as the catalyst particles, well mixed. A tuft of quartz wool is placed on either side of the catalyst mixture to ensure the catalyst bed does not move. Finally the reactor is topped off with 1/16" quartz chips. For a diagram of the reactor, refer to Figure 3.2.

Once the reactor is secured into the system, it is tested for leaks. When it is confirmed that there are no leaks, the pretreatment is begun. For this, the system is purged with helium and heated to $400^{\circ} \mathrm{C}$. Hydrogen is then introduced to the system at $200 \mathrm{cc} / \mathrm{min}$ for 12 hours.

After pretreatment, the reactor is cooled to $300^{\circ} \mathrm{C}$ and pressurized to 300 psig with helium. The reaction is then started by introducing the syngas at a flowrate of $100 \mathrm{cc} / \mathrm{min}$. The reaction proceeds for 72 hours, and then the system is shut down. For shutdown, the syngas flowrate is turned off and helium is once again flowed through the reactor until the reactor is cooled to room temperature. Once the reactor is cooled and the gas flows stopped, the reactor is disconnected from the system and the spent catalyst is collected for later characterization.

While the reaction is proceeding, the GC is set to take a sample from the effluent gas stream every hour. The gas-phase GC data are collected by a program called TotalChrom Workstation. This program automatically identifies and integrates the chromatogram's peaks. In order to calculate the amount of a gas phase component present, the response factor of that component must be acquired through calibration. In order to calibrate, known quantities of the gas to be calibrated are injected with varying amount of diluent. Comparing the amount injected with the response on the GC, the response factor can be calculated. 
The liquid product is collected in 24-hour intervals. The liquid trap is emptied into a graduated cylinder and the volume is recorded. The weight is also measured with an electronic balance, by pouring the liquid into a pre-weighed vial. With the weight and volume recorded, the vial is labeled and stored in the refrigerator to minimize losses while awaiting further analysis. Liquid phase analysis is described in Section 3.3.3.

While each run produces three separate samples, one for each 24-hour period, only the second 24-hour period data are contained in the Results section, in the interest of consistency. The first 24-hour period is considered the startup period where the reaction is still coming to steady state, while the catalyst is considered to be deactivating during the final 24-hour period. This is a typical assumption in laboratory studies such as these.

\subsubsection{Liquid Product Analysis Procedure}

The liquid produced by the reaction is typically a two-phase mixture. The lessdense phase is the oil phase, containing mostly paraffins and olefins. The more-dense phase is the aqueous phase, containing mostly water and alcohols. These two phases are separated before a proper analysis of composition can be begun.

For the oil phase, a sample of the oil, typically $0.1 \mathrm{~mL}$, is mixed with typically 0.9 $\mathrm{mL}$ of $\mathrm{CS}_{2}$. $\mathrm{CS}_{2}$ was chosen as the solvent because it has a very short retention time and a very low response on the FID.

Once the sample is prepared, the vial, along with any other vial to be tested, is placed into the Varian 8100 Autosampler rack. The GC is then started. The temperature program consists of an initial temperature of $50^{\circ} \mathrm{C}$ with a ramping of $10^{\circ} \mathrm{C} / \mathrm{min}$ up to a final temperature of $300^{\circ} \mathrm{C}$. 
The program used to collect the data is the Varian Star Control System. This program automatically integrates any peaks detected; however, the peaks are not identified. The peaks were identified through the use of a calibration mixture. A calibration mixture consists of eight to ten hydrocarbons in the $\mathrm{C}_{1}-\mathrm{C}_{40}$ range at varying concentrations. This gives retention times for the included compounds, and the rest can be determined by inspection.

When calculating the amount of each component in the sample, the assumption is that, for paraffins and olefins, the area percentage on the chromatogram is equal to the weight percentage of the sample.

The aqueous-phase analysis is handled with an internal standard since water is not detected by the column in the GC. The internal standard was chosen to be cyclohexanol. Cyclohexanol was chosen because it was not a compound that would be produced by the FT reaction under normal circumstances, also its retention time was beyond those of the other compounds being detected.

A $1 \mathrm{~mL}$ aliquot of the aqueous sample is transferred to a pre-weighed vial and this is weighed. Then approximately $20 \mu \mathrm{L}$ of cyclohexanol is added to the sample and the weight is recorded. From these numbers, the sample weight and cyclohexanol weight is determined.

These aqueous-phase samples are analyzed by the Varian Autosampler and GC in the same manner as the oil-phase samples described earlier, except that the final temperature in the program is $340^{\circ} \mathrm{C}$ rather than $300^{\circ} \mathrm{C}$. Since there are relatively few alcohol species to be identified, the calibration mixture consists of a single pure alcohol (methanol, ethanol, etc.) mixed with approximately $20 \mu \mathrm{L}$ of cyclohexanol. The retention 
time of the injected component is noted, along with the areas of the component and cyclohexanol.

In order to calculate the amount of each component in the sample, the areas and weights determined from the calibration are used. The corrected area for the component of interest is obtained from:

$$
A_{\text {corr }, i}=A_{i, \text { sample }} \cdot \frac{A_{\text {cyclohexaøl,standard }}}{A_{\text {cyclohexaøl,sample }}} \cdot \frac{W t_{\text {cyclohexaøl,sample }}}{W t_{\text {cyclohexaøl,standard }}}
$$

After obtaining the corrected area, the weight of the compound in the sample can be found from:

$$
W t_{i}=A_{c o r r, i} \cdot \frac{W t_{i, s \operatorname{tandard}}}{A_{i, \text { standard }}}
$$

This calculation is repeated for all the oxygenates in the sample. Once all the oxygenate weights have been determined, the weight of water in the aqueous sample can be found by difference.

\subsection{Safety}

The reactant carbon monoxide is flammable in air at concentrations of $12.5 \%$ to 74.0\%. There is also a danger from inhaling the gas, as it bind's to the hemoglobin in blood and can greatly reduce the blood's ability to transport oxygen in the body. The permissible exposure limit set by OSHA is 50ppm time-weighted average (TWA, the amount a worker can be exposed to over the course of a work day). The material safety data sheet (MSDS) also lists it as a teratogen, a mutagen and a reproductive hazard. Teratogens interfere with normal embryonic development, and mutagens cause higher than normal genetic mutations to occur. 
Hydrogen is also a flammable gas at concentrations between $4.0 \%$ and $74.5 \%$ in air. Hydrogen is not toxic, but will cause asphyxiation.

Neither helium nor nitrogen is flammable or toxic; however, they can cause asphyxiation.

In order to make sure no flammable gas is ignited in the course of the experiment, the reactor is purged with helium prior to each run. This ensures that there is no oxygen left (that could facilitate ignition) in the lines. Also, the reactor system is situated inside a large fume hood to protect personnel from the dangers of inhaling CO. Gas detectors are also wired to the system so that, in the event of a gas release, the system will shut itself down, preventing a larger volume of gas escaping.

To prevent a catastrophic failure due to a plug in the reactor causing a rapid increase in pressure, the reactor system is fitted with pressure relief valves. 


\section{Chapter 4}

\section{Results and Discussion}

The catalysts described in Chapter 3 were prepared and tested in the reactor system of Figure 3.1. Each run was carried out under the same conditions: $300^{\circ} \mathrm{C}$, 300psig, $6 \mathrm{Nl} /$ gcat/h syngas flowrate, with a 1:1 CO: $\mathrm{H}_{2}$ ratio.

First the gas-phase results are discussed, followed by the liquid-phase results, for each catalyst promoter individually. Just as the liquid-phase data are based on the second 24-hour period, the gas-phase results are obtained using the hourly results from the second 24-hour period and averaging them.

Mass balance closures typically range $\pm 4 \%$. Table 4.1 contains the mass balance closure data. A regression analysis of the data and characterization data are also included.

In the following tables, the catalysts will be referred to by the loading of the changing component only. The other components will have the same loading as the base case: $6 \% \mathrm{Mo}, 16 \% \mathrm{Fe}, 0.8 \% \mathrm{Cu}$ and $0.9 \% \mathrm{~K}$.

\begin{tabular}{|l|r|}
\hline \multicolumn{2}{|c|}{ Table 4.1: Mass Balance Error } \\
\hline \multicolumn{1}{|c|}{ Catalyst } & Percent Error \\
\hline 6\%Mo 16\%Fe 0.8\%Cu 0.9\%K & -3.13 \\
\hline 6\%Mo 0\%Fe 0.8\%Cu 0.9\%K & -1.36 \\
\hline 6\%Mo 8\%Fe 0.8\%Cu 0.9\%K & -1.66 \\
\hline 6\%Mo 32\%Fe 0.8\%Cu 0.9\%K & -3.52 \\
\hline 0\%Mo 16\%Fe 0.8\%Cu 0.9\%K & -3.79 \\
\hline 3\%Mo 16\%Fe 0.8\%Cu 0.9\%K & -3.13 \\
\hline 12\%Mo 16\%Fe 0.8\%Cu 0.9\%K & -2.11 \\
\hline 6\%Mo 16\%Fe 0\%Cu 0.9\%K & -3.91 \\
\hline 6\%Mo 16\%Fe 0.4\%Cu 0.9\%K & -0.94 \\
\hline 6\%Mo 16\%Fe 1.6\%Cu 0.9\%K & -0.31 \\
\hline 6\%Mo 16\%Fe 0.8\%Cu 0\%K & -3.73 \\
\hline 6\%Mo 16\%Fe 0.8\%Cu 0.45\%K & -4.31 \\
\hline 6\%Mo 16\%Fe 0.8\%Cu 1.8\%K & -0.54 \\
\hline
\end{tabular}




\subsection{Effect of Varying Mo}

The conversions for each Mo catalyst are shown in Figure 4.1. It can be seen that the reaction never get to steady state. The conversion for the $0 \%$ Mo catalyst starts off with the highest conversion; however, it deactivates quickly. The other Mo-containing catalysts show a higher stability. The 6\%Mo catalyst shows higher conversion than the $3 \% \mathrm{Mo}$ and $12 \%$ Mo catalysts, with the $12 \%$ Mo catalyst having the lowest conversion of all. Table 4.2 shows the average conversions for each catalyst during the 24-48 hour period. These results are consistent with those of Ma et al. ${ }^{10}$ using catalysts with Mo, Fe, $\mathrm{Cu}$ and $\mathrm{K}$ present.

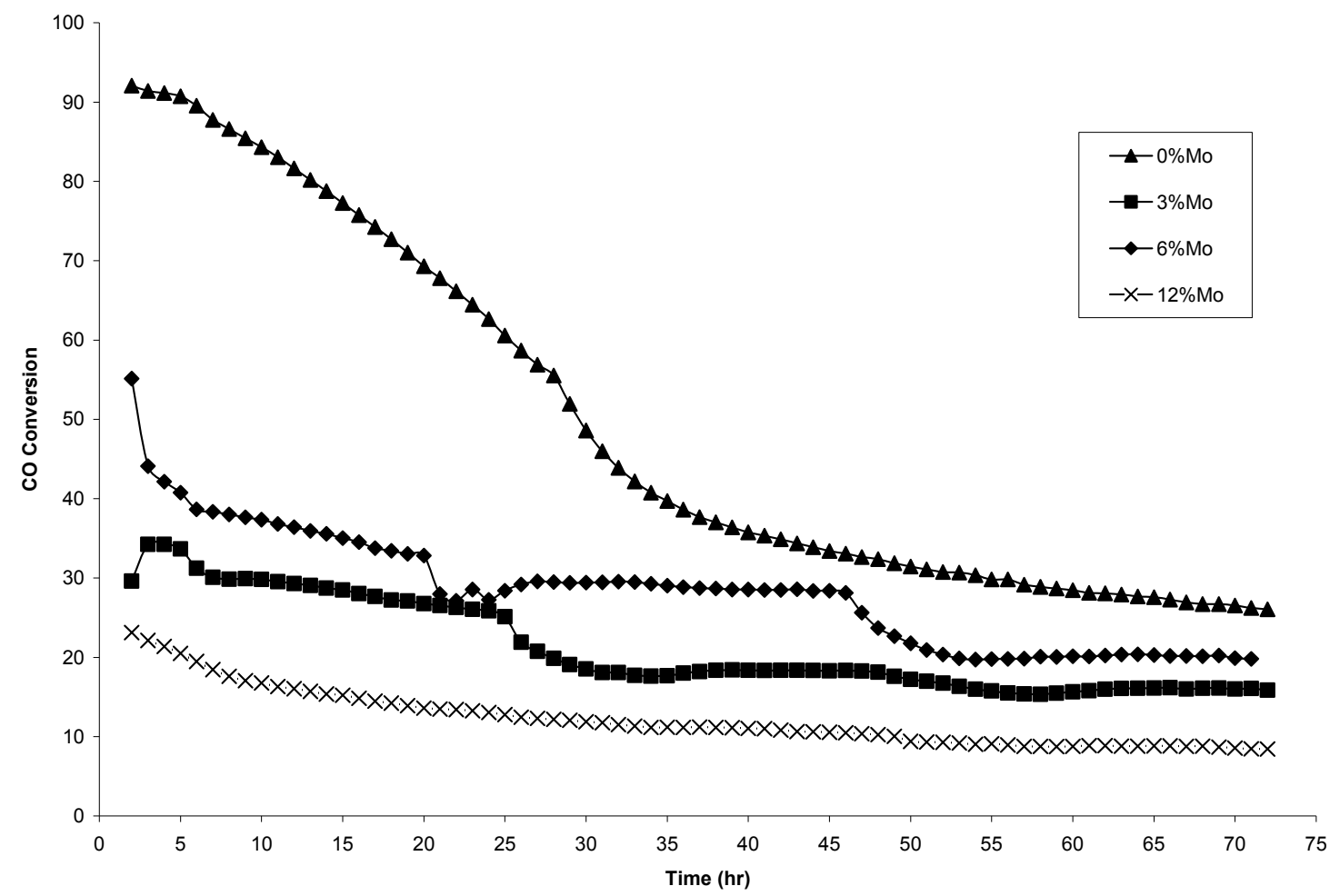

Figure 4.1: CO Conversion Comparison for Iron Catalysts of Varying Mo Composition 


\begin{tabular}{|c|c|}
\hline \multicolumn{2}{|c|}{$\begin{array}{l}\text { Table 4.2: Average CO Conversion between 24-48 Hours } \\
\text { for Varying Mo Catalysts }\end{array}$} \\
\hline Catalyst & Conversion (\%) \\
\hline $0 \% \mathrm{Mo}$ & 42.5 \\
\hline 3\%Мo & 19.1 \\
\hline $6 \% \mathrm{Mo}$ & 28.5 \\
\hline 12\%Мо & 11.4 \\
\hline
\end{tabular}

The selectivities for the gas phase components are listed in Table 4.3. It can be seen that the addition of Mo causes a decrease in $\mathrm{CO}_{2}$ production and an increase in $\mathrm{CH}_{4}$ production. This is consistent with the findings of Ma et $\mathrm{al}^{10}$.

\begin{tabular}{|c|c|c|c|c|c|c|c|c|}
\hline \multicolumn{10}{|c|}{ Table 4.3: Average Gas Phase Component Selectivities and Amounts (mmols/day) for } \\
\hline \multirow{2}{*}{ Compound } & \multicolumn{2}{|c|}{$0 \%$ Mo } & \multicolumn{2}{c|}{$3 \%$ Mo } & \multicolumn{2}{c|}{$6 \%$ Mo } & \multicolumn{2}{c|}{$12 \%$ Mo } \\
\cline { 2 - 10 } & Select & Amount & Select & Amount & Select & Amount & Select & Amount \\
\hline $\mathrm{CO}_{2}$ & 76.52 & 679 & 71.13 & 290 & 69.64 & 432 & 63.15 & 168 \\
\hline $\mathrm{CH}_{4}$ & 6.94 & 61.6 & 11.99 & 48.9 & 12.86 & 79.8 & 17.93 & 47.7 \\
\hline $\mathrm{C}_{2} \mathrm{H}_{6} / \mathrm{C}_{2} \mathrm{H}_{4}$ & 5.73 & 50.9 & 5.81 & 23.7 & 6.14 & 38.1 & 6.95 & 18.5 \\
\hline $\mathrm{C}_{3} \mathrm{H}_{8}$ & 0.54 & 4.80 & 1.07 & 4.35 & 1.17 & 7.27 & 1.29 & 3.43 \\
\hline $\mathrm{C}_{3} \mathrm{H}_{6}$ & 4.75 & 42.1 & 4.17 & 17.0 & 4.45 & 27.6 & 5.07 & 13.5 \\
\hline $\mathrm{i}-\mathrm{C}_{4} \mathrm{H}_{10}$ & 0.06 & 0.54 & 0.03 & 0.12 & 0.04 & 0.24 & 0.00 & 0.00 \\
\hline $\mathrm{n}-\mathrm{C}_{4} \mathrm{H}_{10}$ & 0.31 & 2.73 & 0.58 & 2.38 & 0.62 & 3.84 & 0.62 & 1.64 \\
\hline $1-\mathrm{C}_{4} \mathrm{H}_{8}$ & 2.30 & 20.4 & 1.49 & 6.08 & 1.34 & 8.32 & 1.00 & 2.66 \\
\hline $\mathrm{i}-\mathrm{C}_{4} \mathrm{H}_{8}$ & 0.27 & 2.43 & 0.00 & 0.00 & 0.00 & 0.00 & 0.00 & 0.00 \\
\hline trans- $\mathrm{C}_{4} \mathrm{H}_{8}$ & 0.04 & 0.38 & 0.29 & 1.19 & 0.43 & 2.68 & 0.40 & 1.07 \\
\hline $\mathrm{cis}-\mathrm{C}_{4} \mathrm{H}_{8}$ & 0.06 & 0.50 & 0.34 & 1.37 & 0.48 & 3.00 & 0.41 & 1.08 \\
\hline $1,3-\mathrm{C}_{4} \mathrm{H}_{6}$ & 0.00 & 0.00 & 0.00 & 0.00 & 0.00 & 0.00 & 0.00 & 0.00 \\
\hline $\mathrm{i}-\mathrm{C}_{5} \mathrm{H}_{12}$ & 0.03 & 0.27 & 0.00 & 0.00 & 0.00 & 0.00 & 0.00 & 0.00 \\
\hline $\mathrm{n}-\mathrm{C}_{5} \mathrm{H}_{12}$ & 0.24 & 2.16 & 0.54 & 2.21 & 0.57 & 3.51 & 0.52 & 1.39 \\
\hline $\mathrm{C}_{5+}$ & 2.20 & 19.6 & 2.55 & 10.4 & 2.26 & 14.0 & 2.66 & 7.07 \\
\hline
\end{tabular}

Appendix I contains the numbers for the aqueous products produced by Mo catalysts along with the base case. Table 4.4 shows a breakdown of the aqueous product masses. Figure 4.2 shows the selectivity for the five alcohol carbon numbers. For increasing Mo composition, the methanol production is increasing. The amount of ethanol produced decreases sharply with the addition of any Mo on the catalyst. These are both also seen in the study done by $\mathrm{Ma}^{10}$. 
Amounts of individual compounds found in the oil fraction of the liquid phase produced by Mo catalysts are shown in detail in Appendix II. Table 4.5 contains information on the oil product lumped into three groups: $\mathrm{C}_{6}$ through $\mathrm{C}_{8}$, $\mathrm{C}_{9}$ through $\mathrm{C}_{15}$, and $\mathrm{C}_{16+}$. The reasoning is that this project focuses on producing diesel fuel which is in the $\mathrm{C}_{9}$ to $\mathrm{C}_{15}$ range. The $3 \%$ Mo has the largest percentage of oil produced in this range.

Figure 4.3 shows the selectivities for each carbon number in the oil phase.

\begin{tabular}{|c|c|c|c|c|}
\hline \multicolumn{5}{|c|}{ Table 4.4: Aqueous Product Amounts for Catalysts of Varying Mo } \\
\hline \multirow{2}{*}{ Compound } & \multicolumn{4}{|c|}{$\mathrm{mmol}$} \\
\hline & $0 \% \mathrm{Mo}$ & 3\%Mo & 6\%Mo & $12 \% \mathrm{Mo}$ \\
\hline Methanol & 1.13 & 2.77 & 8.20 & 4.72 \\
\hline Ethanol & 2.89 & 4.77 & 11.25 & 4.05 \\
\hline 2-Propanol & 0.04 & 0.61 & 1.38 & 0.42 \\
\hline 1-Propanol & 0.87 & 1.28 & 4.38 & 1.11 \\
\hline 2-Butanol & 0.00 & 0.16 & 0.42 & 0.10 \\
\hline 1-Butanol & 0.51 & 1.60 & 2.64 & 0.83 \\
\hline 2-Pentanol & 0.00 & 0.01 & 0.01 & 0.00 \\
\hline 1-Pentanol & 0.20 & 0.88 & 1.20 & 0.40 \\
\hline Water & 21.96 & 25.70 & 30.53 & 21.67 \\
\hline
\end{tabular}

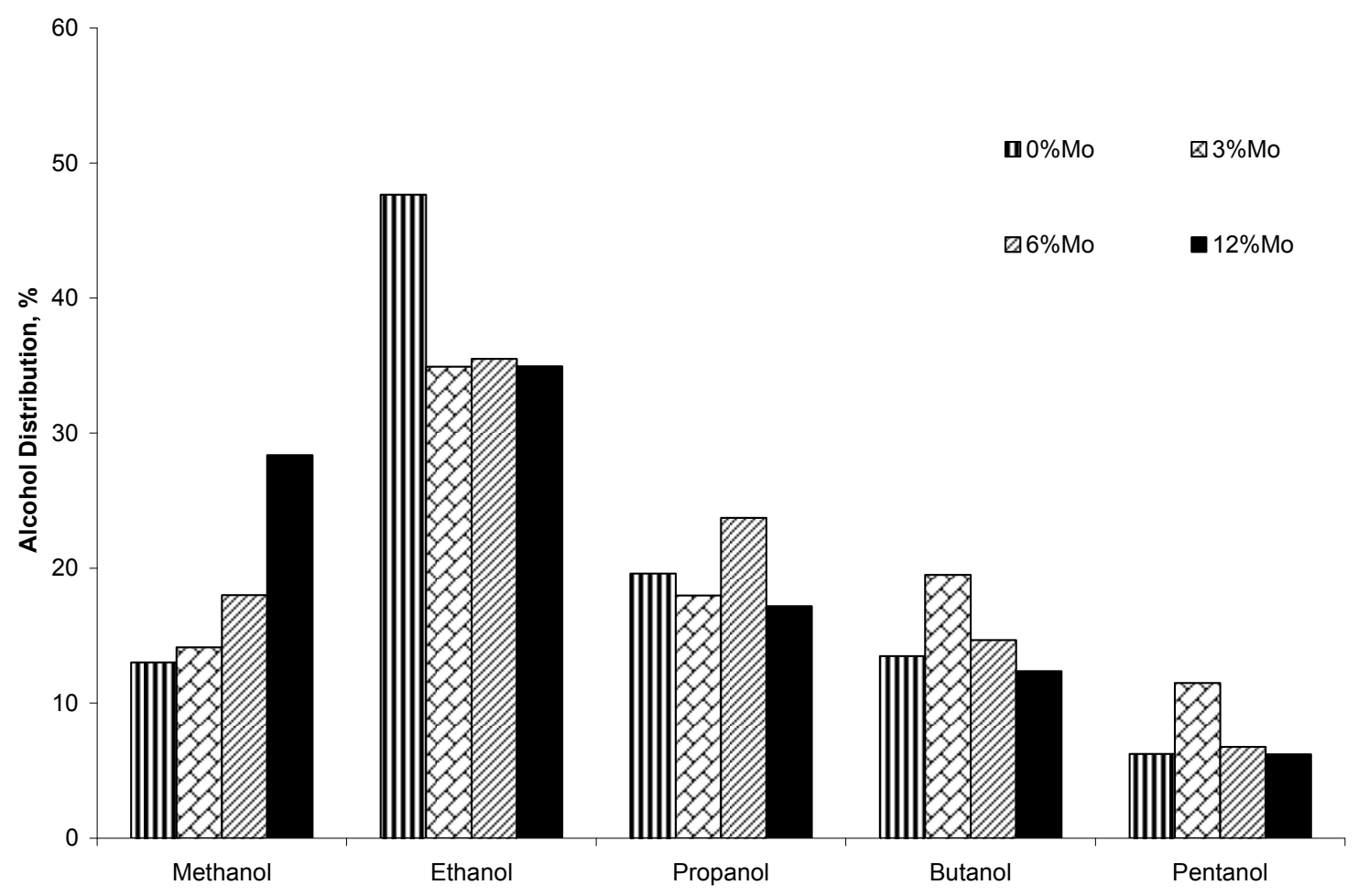

Figure 4.2: Alcohol Distribution for Catalysts of Varying Mo Content 


\begin{tabular}{|c|c|c|c|}
\hline \multicolumn{3}{|c|}{ Table 4.5 Lumped Oil Product Distribution for Varied Mo Catalysts } \\
\hline \multirow{2}{*}{ Catalysts } & \multicolumn{3}{|c|}{ Selectivity } \\
\cline { 2 - 4 } & $\mathrm{C}_{6}-\mathrm{C}_{8}$ & $\mathrm{C}_{9}-\mathrm{C}_{15}$ & $\mathrm{C}_{16+}$ \\
\hline $0 \% \mathrm{Mo}$ & 48.1 & 51.4 & 0.5 \\
\hline $3 \% \mathrm{Mo}$ & 38.8 & 61.2 & 0.0 \\
\hline $6 \% \mathrm{Mo}$ & 48.8 & 51.2 & 0.0 \\
\hline $12 \% \mathrm{Mo}$ & 100 & 0.0 & 0.0 \\
\hline
\end{tabular}

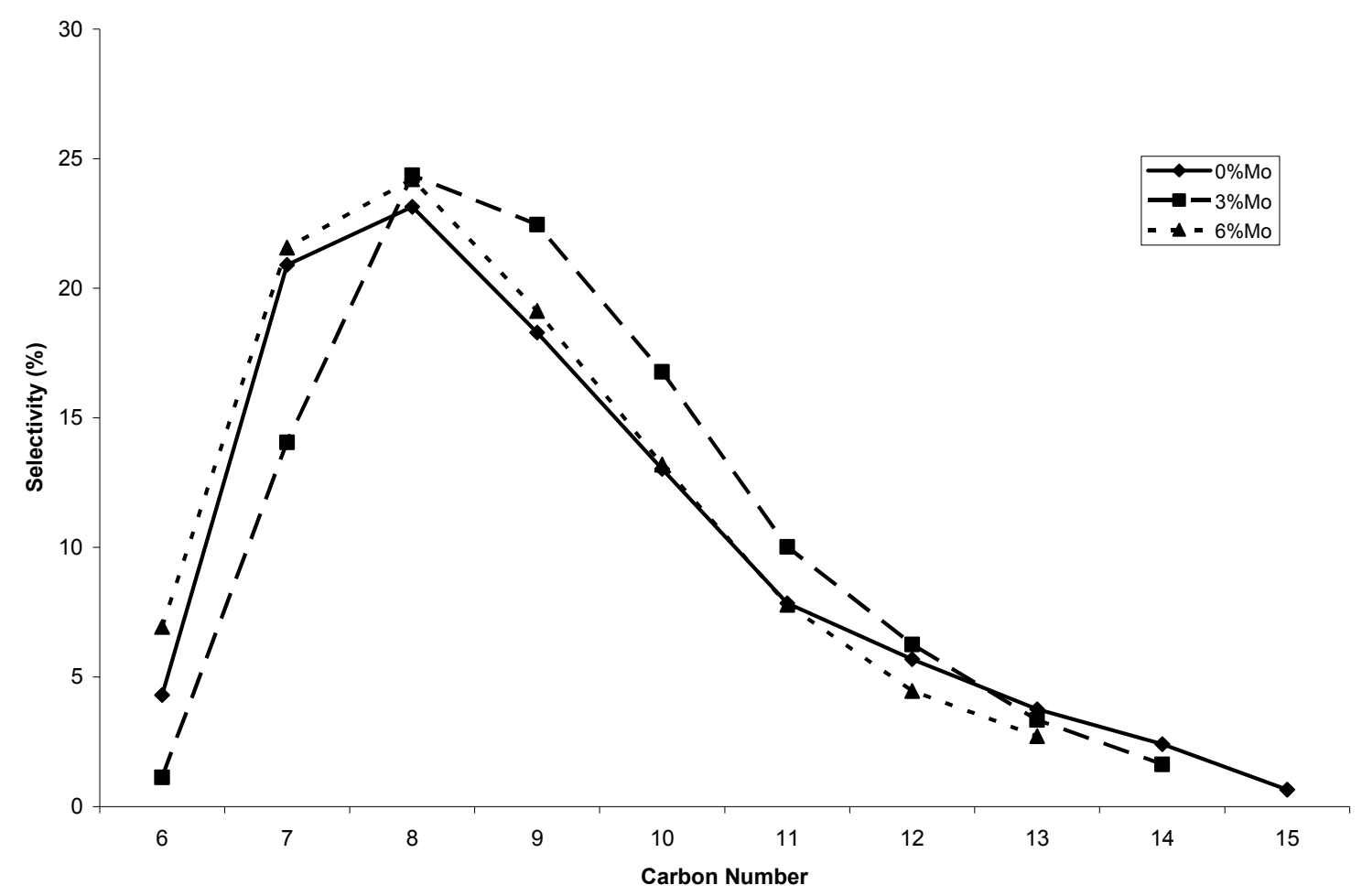

Figure 4.3: Oil Fraction Selectivity for Varying Mo

Table 4.6 contains broad properties of the total liquid products. Mo causes an increase in the total alcohol production up to $6 \%$; at $12 \%$, the total alcohol production falls off. This is consistent with the results of Ma et $\mathrm{al}^{10}$. Addition of Mo also causes a decrease in the total oil production as well as the olefin-to-paraffin ratio. This is inconsistent with the results of $\mathrm{Ma}$ et al who reported ${ }^{10}$ that the olefin-to-paraffin ratios are similar for all Mo catalysts. The addition of $12 \%$ Mo caused a drastic increase in oil production where the highest carbon number observed was 8 . This is not consistent with 
the results of Ma et al who reported an increase in higher molecular weight species with $12 \%$ Mo.

\begin{tabular}{|c|c|c|c|c|c|c|}
\hline \multicolumn{6}{|c|}{ Table 4.6: Liquid Product Properties for Catalysts of Varying Mo Composition } \\
\hline Catalyst & $\begin{array}{c}\text { Total } \\
\text { Alcohol } \\
\text { Weight } \\
\text { (mg) }\end{array}$ & $\begin{array}{c}\text { Percent } \\
\text { Alcohol } \\
\text { in Water }\end{array}$ & $\begin{array}{c}\text { Total Oil } \\
\text { Weight } \\
\text { (mg) }\end{array}$ & $\begin{array}{c}\text { Highest } \\
\text { Carbon } \\
\text { Number }\end{array}$ & $\frac{\text { Alcohols }}{\text { HCs }}$ (\%) & $\frac{\text { Olefins }}{\text { Paraffins }}(\%)$ \\
\hline $0 \% \mathrm{Mo}$ & 279 & 41.4 & 3660 & 17 & 7.6 & 61.3 \\
\hline $3 \% \mathrm{Mo}$ & 629 & 57.6 & 737 & 16 & 85.3 & 20.7 \\
\hline $6 \% \mathrm{Mo}$ & 1460 & 72.6 & 675 & 20 & 216 & 15.1 \\
\hline $12 \% \mathrm{Mo}$ & 534 & 57.8 & 440 & 8 & 121 & 0.0 \\
\hline
\end{tabular}

\subsection{Effect of Varying Fe}

Figure 4.4 shows the results for $\mathrm{CO}$ conversion of the Fe catalysts. As can be expected, the general trend is that conversion increases with higher Fe content. Table 4.7 shows the average conversions for the 24-48 hour period. The effect of Fe loading was not studied by Ma.

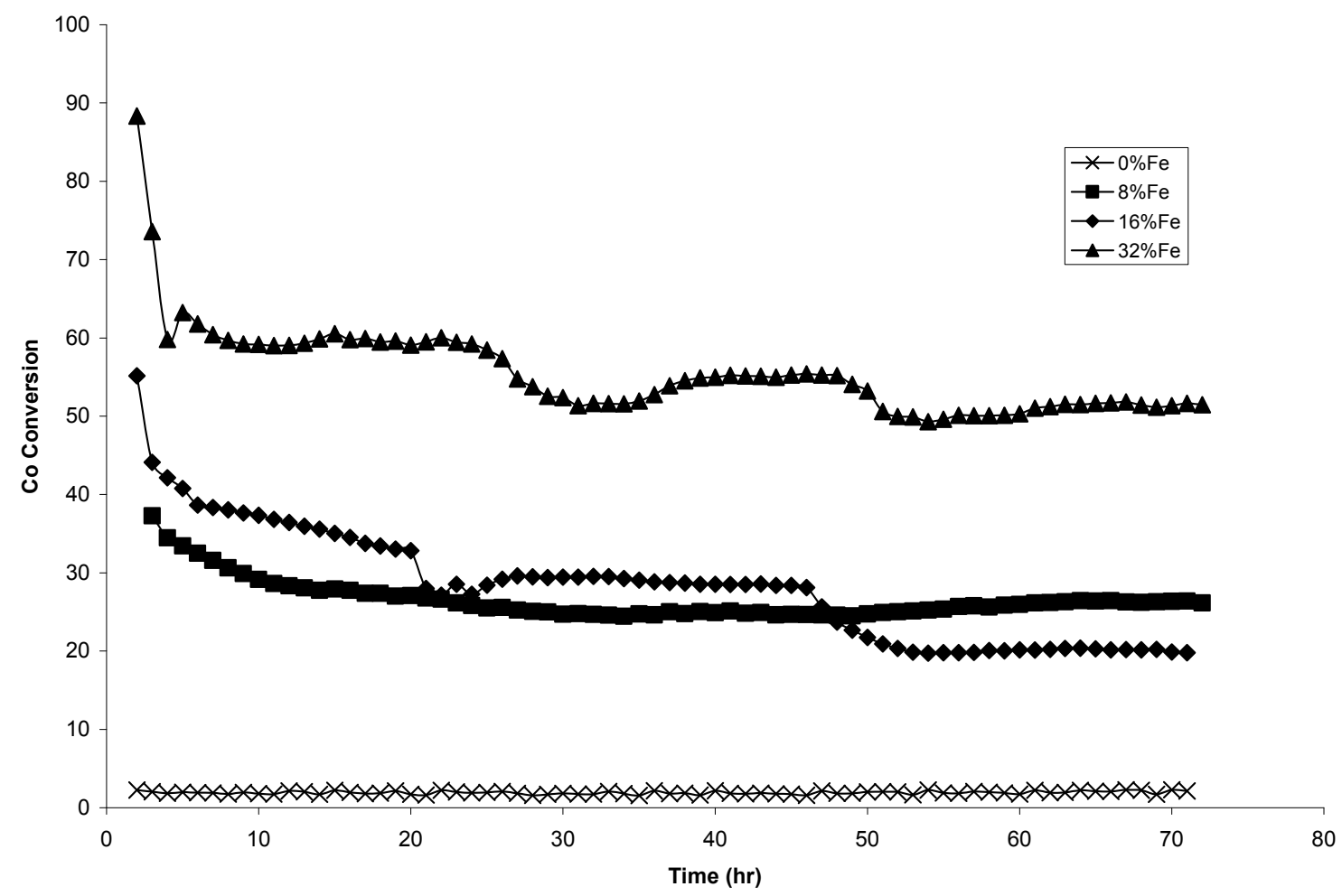

Figure 4.4: CO Conversion Comparison for Iron Catalysts of Varying Fe Composition 


\begin{tabular}{|c|c|}
\hline & \\
\hline $\begin{array}{r}\text { Cdtalyst } \\
0 / 50\end{array}$ & Conversion (\%) \\
\hline $0 \% \mathrm{Fe}$ & 1.8 \\
\hline $8 \% \mathrm{Fe}$ & 24.9 \\
\hline $16 \% \mathrm{Fe}$ & 28.5 \\
\hline $32 \% \mathrm{Fe}$ & 54.4 \\
\hline
\end{tabular}

Table 4.8 contains information on the average gas component selectivites. For the $0 \% \mathrm{Fe}$ case, the reaction produces nothing more than small amounts of methane. The other Fe catalysts show a decreasing $\mathrm{CO}_{2}$ production and increasing $\mathrm{CH}_{4}$ production with higher Fe composition.

\begin{tabular}{|c|c|c|c|c|c|c|c|c|}
\hline \multicolumn{9}{|c|}{$\begin{array}{l}\text { Table 4.8: Average Gas Phase Component Selectivities and Amounts (mmols) for } \\
\text { Varying Fe Catalysts }\end{array}$} \\
\hline \multirow{2}{*}{ Compound } & \multicolumn{2}{|c|}{$0 \% \mathrm{Fe}$} & \multicolumn{2}{|c|}{$8 \% \mathrm{Fe}$} & \multicolumn{2}{|c|}{$16 \% \mathrm{Fe}$} & \multicolumn{2}{|c|}{$32 \% \mathrm{Fe}$} \\
\hline & Select & Amount & Select & Amount & Select & Amount & Select & Amount \\
\hline $\mathrm{CO}_{2}$ & 0.00 & 0.00 & 71.14 & 352 & 69.64 & 432 & 66.29 & 824 \\
\hline $\mathrm{CH}_{4}$ & 100 & 30.6 & 12.72 & 62.9 & 12.86 & 79.8 & 14.86 & 185 \\
\hline $\mathrm{C}_{2} \mathrm{H}_{6} / \mathrm{C}_{2} \mathrm{H}_{4}$ & 0.00 & 0.00 & 5.60 & 27.7 & 6.14 & 38.1 & 6.54 & 81.3 \\
\hline $\mathrm{C}_{3} \mathrm{H}_{8}$ & 0.00 & 0.00 & 1.51 & 7.46 & 1.17 & 7.27 & 1.76 & 21.9 \\
\hline $\mathrm{C}_{3} \mathrm{H}_{6}$ & 0.00 & 0.00 & 3.65 & 18.0 & 4.45 & 27.6 & 4.26 & 52.9 \\
\hline $\mathrm{i}-\mathrm{C}_{4} \mathrm{H}_{10}$ & 0.00 & 0.00 & 0.04 & 0.21 & 0.04 & 0.24 & 0.05 & 0.63 \\
\hline$n-C_{4} H_{10}$ & 0.00 & 0.00 & 0.72 & 3.57 & 0.62 & 3.84 & 0.84 & 10.5 \\
\hline $1-\mathrm{C}_{4} \mathrm{H}_{8}$ & 0.00 & 0.00 & 0.87 & 4.31 & 1.34 & 8.32 & 1.02 & 12.6 \\
\hline $\mathrm{i}-\mathrm{C}_{4} \mathrm{H}_{8}$ & 0.00 & 0.00 & 0.25 & 1.25 & 0.00 & 0.00 & 0.30 & 3.67 \\
\hline trans- $\mathrm{C}_{4} \mathrm{H}_{8}$ & 0.00 & 0.00 & 0.46 & 2.25 & 0.43 & 2.68 & 0.53 & 6.62 \\
\hline cis- $\mathrm{C}_{4} \mathrm{H}_{8}$ & 0.00 & 0.00 & 0.49 & 2.40 & 0.48 & 3.00 & 0.57 & 7.05 \\
\hline $1,3-\mathrm{C}_{4} \mathrm{H}_{6}$ & 0.00 & 0.00 & 0.00 & 0.00 & 0.00 & 0.00 & 0.00 & 0.00 \\
\hline $\mathrm{i}-\mathrm{C}_{5} \mathrm{H}_{12}$ & 0.00 & 0.00 & 0.05 & 0.23 & 0.00 & 0.00 & 0.06 & 0.69 \\
\hline $\mathrm{n}-\mathrm{C}_{5} \mathrm{H}_{12}$ & 0.00 & 0.00 & 0.64 & 3.17 & 0.57 & 3.51 & 0.75 & 9.29 \\
\hline $\mathrm{C}_{5+}$ & 0.00 & 0.00 & 1.86 & 9.19 & 2.26 & 14.0 & 2.17 & 27.0 \\
\hline
\end{tabular}

Appendix III contains data for the aqueous phase for Fe catalysts. Table 4.9 contains information on the masses of the aqueous phase components. Figure 4.5 includes information on the alcohol phase selectivities. As mentioned before, the $0 \% \mathrm{Fe}$ catalyst produced no liquid product. 


\begin{tabular}{|c|c|c|c|c|}
\hline \multicolumn{5}{|c|}{ Table 4.9: Aqueous Product Amounts for Catalysts of Varying Fe } \\
\hline \multirow{2}{*}{ Compound } & \multicolumn{4}{|c|}{ mmol } \\
\hline & $0 \% \mathrm{Fe}$ & $8 \% \mathrm{Fe}$ & $16 \% \mathrm{Fe}$ & $32 \% \mathrm{Fe}$ \\
\hline Methanol & 0.00 & 7.28 & 8.20 & 7.59 \\
\hline Ethanol & 0.00 & 9.91 & 11.25 & 11.05 \\
\hline 2-Propanol & 0.00 & 0.98 & 1.38 & 1.53 \\
\hline 1-Propanol & 0.00 & 4.19 & 4.38 & 0.40 \\
\hline 2-Butanol & 0.00 & 0.26 & 0.42 & 0.40 \\
\hline 1-Butanol & 0.00 & 1.76 & 2.64 & 2.29 \\
\hline 2-Pentanol & 0.00 & 0.01 & 0.01 & 0.01 \\
\hline 1-Pentanol & 0.00 & 0.72 & 1.20 & 1.57 \\
\hline Water & 0.00 & 26.37 & 30.53 & 56.80 \\
\hline
\end{tabular}

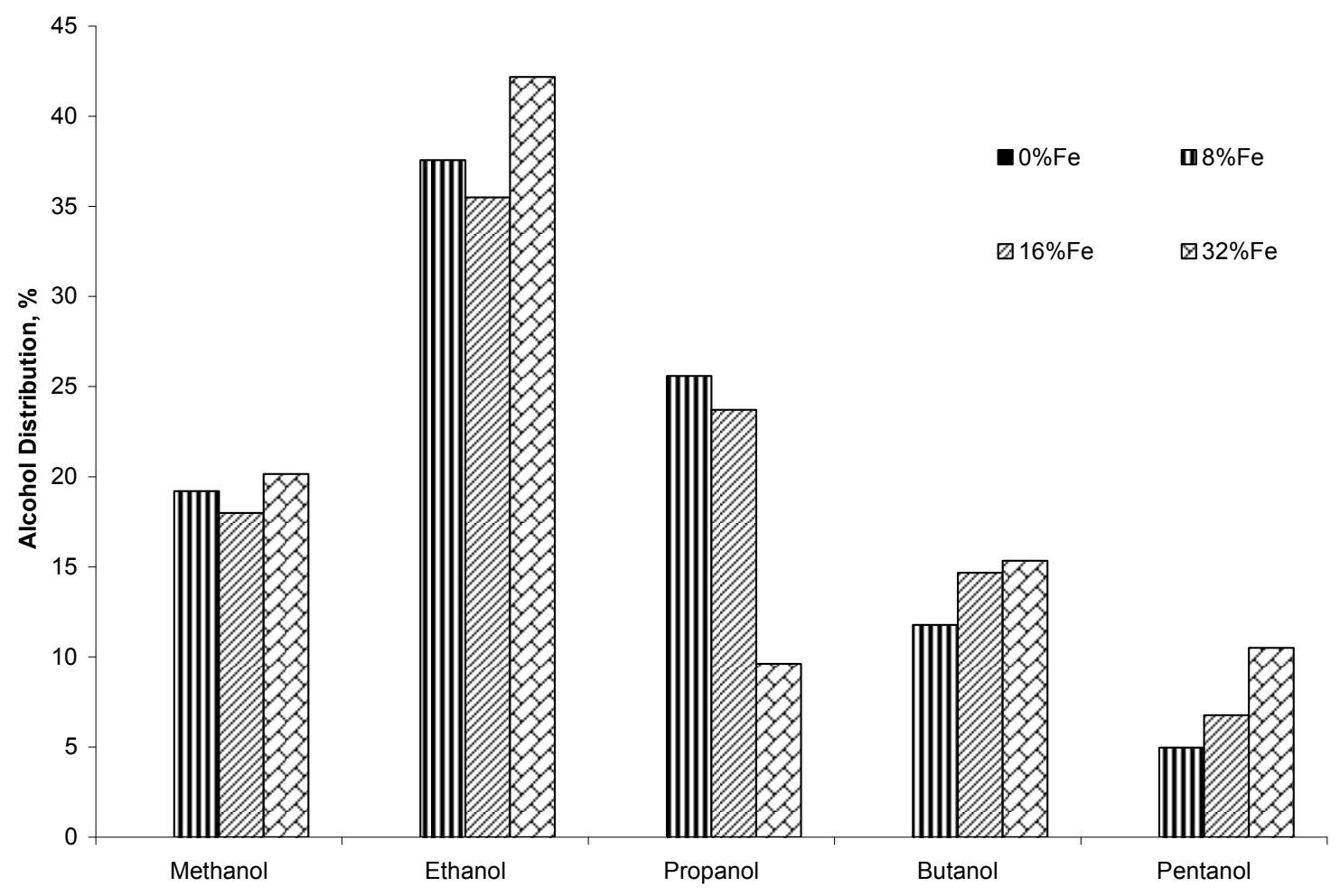

Figure 4.5: Alcohol Distribution for Catalysts of Varying Fe Content

Amounts of individual compounds found in the oil fraction of the liquid phase are shown in detail in Appendix IV. Table 4.10 contains the percentages for the lumped oil product distribution. The $8 \% \mathrm{Fe}$ catalyst produced the largest percentage of $\mathrm{C}_{9}-\mathrm{C}_{15}$ hydrocarbons. Figure 4.6 shows the selectivity for the oil fraction by carbon number 


\begin{tabular}{|c|c|c|c|}
\hline \multirow{2}{*}{ Table 4.10: Lumped Oil Product Distribution for Varied Mo Catalysts } \\
\hline \multirow{2}{*}{ Catalysts } & \multicolumn{3}{|c|}{ Selectivity } \\
\cline { 2 - 4 } & $\mathrm{C}_{6}-\mathrm{C}_{8}$ & $\mathrm{C}_{9}-\mathrm{C}_{15}$ & $\mathrm{C}_{16+}$ \\
\hline $0 \% \mathrm{Fe}$ & 0.0 & 0.0 & 0.0 \\
\hline $8 \% \mathrm{Fe}$ & 36.2 & 60.6 & 3.2 \\
\hline $16 \% \mathrm{Fe}$ & 48.8 & 51.2 & 0.0 \\
\hline $32 \% \mathrm{Fe}$ & 46.8 & 51.7 & 1.5 \\
\hline
\end{tabular}

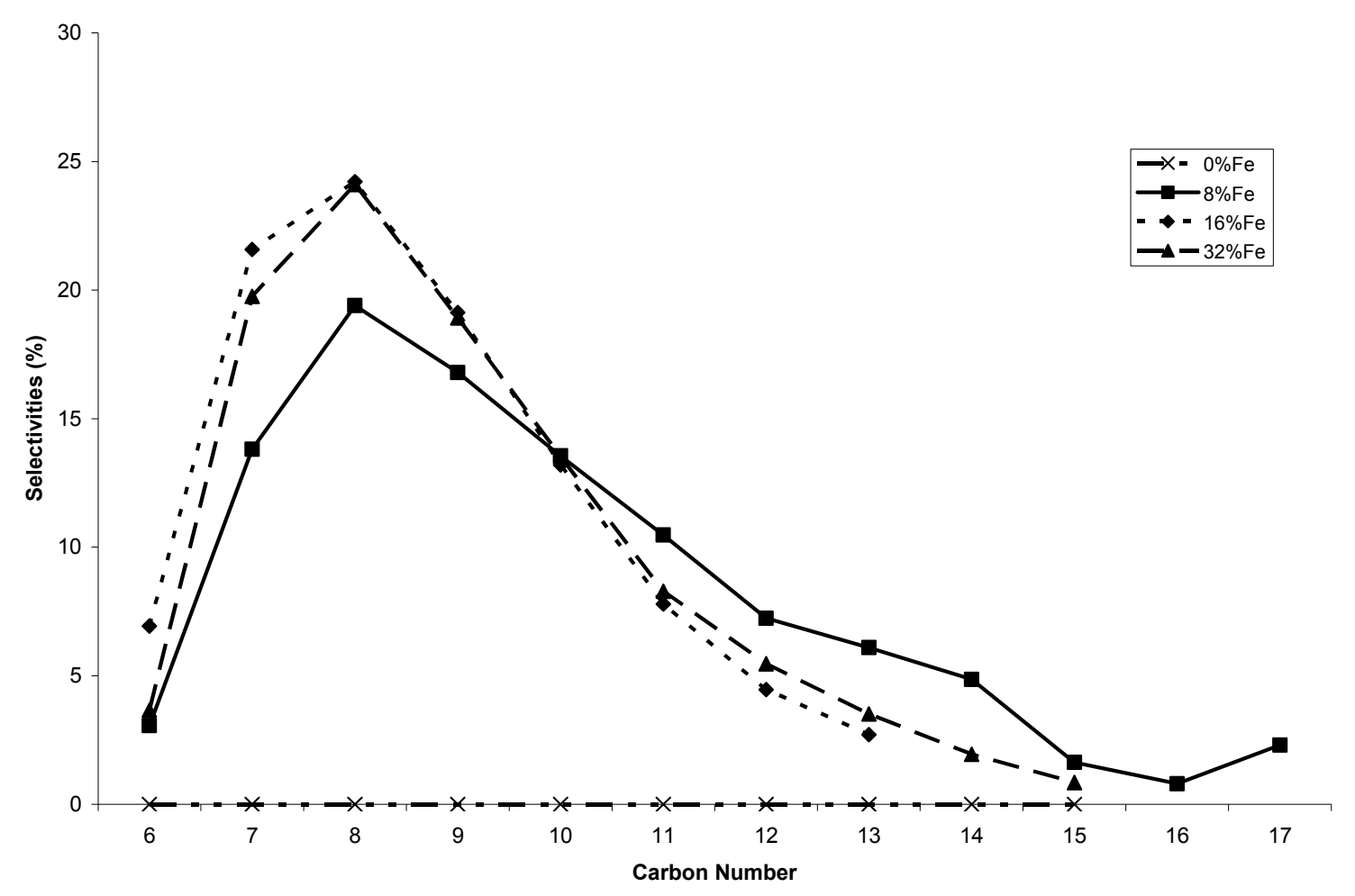

Figure 4.6: Oil Fraction Selectivity for Varying Fe

An overview of the total liquid properties collected for the Fe catalysts is contained in Table 4.11. The $0 \% \mathrm{Fe}$ catalyst performs expectedly, producing no liquid product. The oil production increases with Fe loading, while the alcohol production stays roughly constant.

\begin{tabular}{|c|c|c|c|c|c|c|}
\hline \multicolumn{6}{|c|}{ Table 4.11: Liquid Product Properties for Catalysts of Varying Fe Composition } \\
\hline Catalyst & $\begin{array}{c}\text { Total } \\
\text { Alcohol } \\
\text { Weight } \\
(\mathrm{mg})\end{array}$ & $\begin{array}{c}\text { Percent } \\
\text { Alcohol } \\
\text { in Water }\end{array}$ & $\begin{array}{c}\text { Total } \\
\text { Oil } \\
\text { Weight } \\
(\mathrm{mg})\end{array}$ & $\begin{array}{c}\text { Highest } \\
\text { Carbon } \\
\text { Number }\end{array}$ & $\frac{\text { Alcohols }}{\text { HCs }}(\%)$ & $\frac{\text { Olefins }}{\text { Paraffins }}(\%)$ \\
\hline $0 \% \mathrm{Fe}$ & 0 & 0.0 & 0 & 0 & 0.0 & 0.0 \\
\hline $8 \% \mathrm{Fe}$ & 1215 & 71.9 & 550 & 17 & 220 & 23.1 \\
\hline $16 \% \mathrm{Fe}$ & 1460 & 72.6 & 675 & 20 & 216 & 15.1 \\
\hline $32 \% \mathrm{Fe}$ & 1207 & 54.1 & 1570 & 20 & 76.9 & 18.5 \\
\hline
\end{tabular}




\subsection{Effect of Varying Cu}

Figure 4.7 shows the conversion data for the $\mathrm{Cu}$ catalysts. The change in $\mathrm{Cu}$ composition does not affect the conversion is a large way. Table 4.12 shows the average conversion between the period of 24-48 hours. The change in average conversion is on the order of $\pm 6 \%$. Ma et al reported ${ }^{22}$, using catalysts containing only $\mathrm{Fe}, \mathrm{Cu}$ and $\mathrm{K}$, that the conversion decreased with the addition of $\mathrm{Cu}$. However, the change from $0.8 \% \mathrm{Cu}$ to 2\%Cu did not affect the conversion significantly.

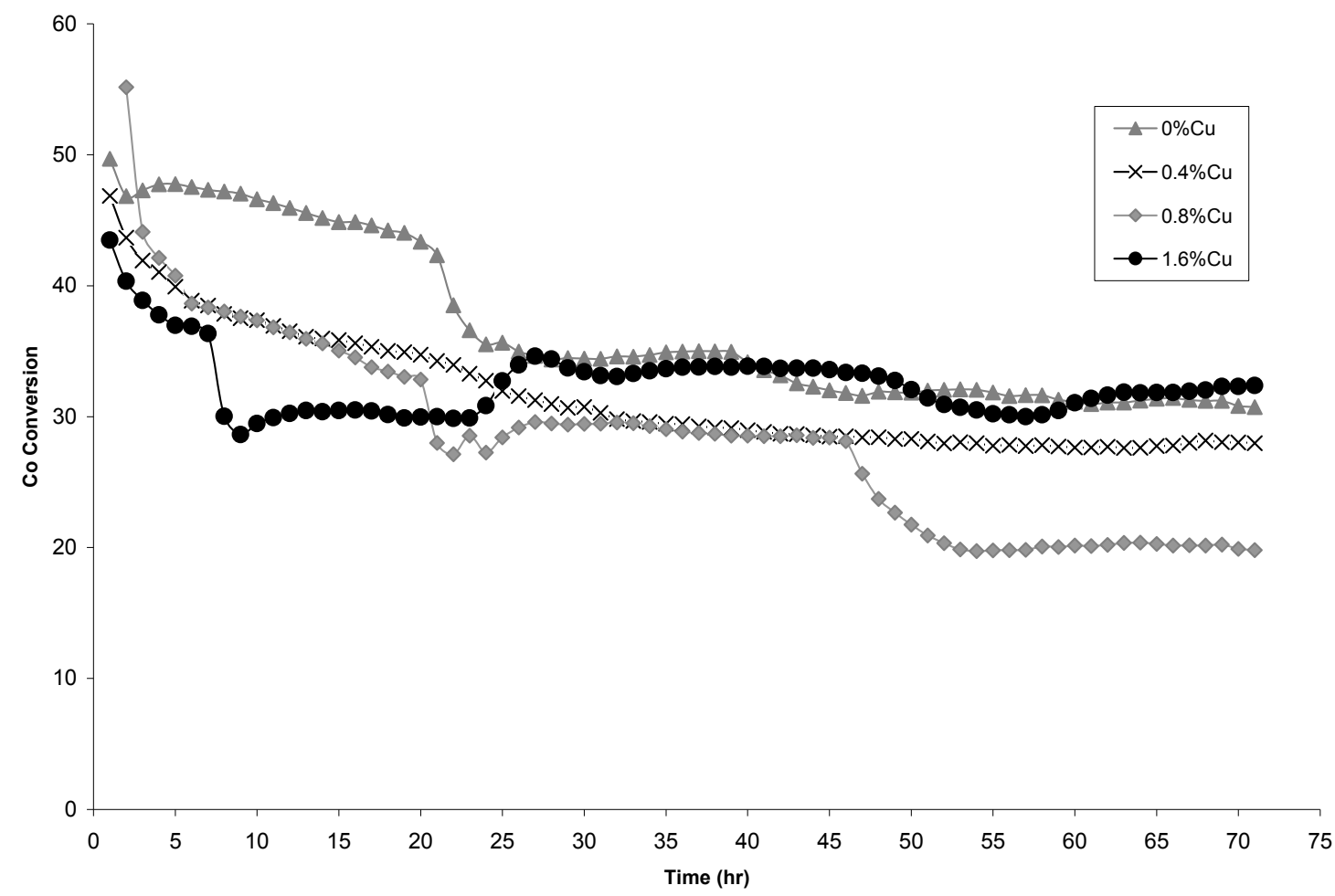

Figure 4.7: CO Conversion Comparison for Iron Catalysts of Varying Cu Composition

\begin{tabular}{|l|r|}
\hline \multicolumn{2}{|c|}{$\begin{array}{c}\text { Table 4.12: Average CO Conversion between 24-48 Hours } \\
\text { for Varying Cu Catalysts }\end{array}$} \\
\hline \multicolumn{1}{|c|}{ Catalyst } & Conversion (\%) \\
\hline $0 \% \mathrm{Cu}$ & 34.2 \\
\hline $0.4 \% \mathrm{Cu}$ & 29.2 \\
\hline $0.8 \% \mathrm{Cu}$ & 28.5 \\
\hline $1.6 \% \mathrm{Cu}$ & 33.4 \\
\hline
\end{tabular}


The selectivities for the gas phase components are listed in Table 4.13. Just as the conversions were not changed in any significant way, the gas selectivities were very similar between catalysts. This is consistent with Ma et $\mathrm{al}^{22}$. For the simpler catalysts studied by Ma, the production of $\mathrm{CO}$ and $\mathrm{CH}_{4}$ were similar across all catalysts.

\begin{tabular}{|c|c|c|c|c|c|c|c|c|}
\hline \multicolumn{7}{|c|}{ Table 4.13: Average Gas Phase Component Selectivities and Amounts (mmols) for } \\
\hline \multirow{2}{*}{ Compound } & \multicolumn{2}{|c}{$0 \% \mathrm{Cu}$} & \multicolumn{2}{c|}{$0.4 \% \mathrm{Cu}$} & \multicolumn{2}{c|}{$0.8 \% \mathrm{Cu}$} & \multicolumn{2}{c|}{$1.6 \% \mathrm{Cu}$} \\
\cline { 2 - 10 } & Select & Amount & Select & Amount & Select & Amount & Select & Amount \\
\hline $\mathrm{CO}_{2}$ & 69.86 & 516 & 68.05 & 494 & 69.64 & 432 & 72.74 & 505 \\
\hline $\mathrm{CH}_{4}$ & 12.52 & 92.5 & 13.10 & 95.1 & 12.86 & 79.8 & 14.84 & 103 \\
\hline $\mathrm{C}_{2} \mathrm{H}_{6} / \mathrm{C}_{2} \mathrm{H}_{4}$ & 6.01 & 44.4 & 7.80 & 56.6 & 6.14 & 38.1 & 5.82 & 40.4 \\
\hline $\mathrm{C}_{3} \mathrm{H}_{8}$ & 1.37 & 10.2 & 1.21 & 8.78 & 1.17 & 7.27 & 2.87 & 19.9 \\
\hline $\mathrm{C}_{3} \mathrm{H}_{6}$ & 4.27 & 31.6 & 4.21 & 30.6 & 4.45 & 27.6 & 0.93 & 6.43 \\
\hline $\mathrm{i}-\mathrm{C}_{4} \mathrm{H}_{10}$ & 0.04 & 0.32 & 0.05 & 0.36 & 0.04 & 0.24 & 0.07 & 0.50 \\
\hline $\mathrm{n}-\mathrm{C}_{4} \mathrm{H}_{10}$ & 0.69 & 5.09 & 0.61 & 4.43 & 0.62 & 3.84 & 0.96 & 6.67 \\
\hline $1-\mathrm{C}_{4} \mathrm{H}_{8}$ & 1.19 & 8.65 & 1.11 & 8.06 & 1.34 & 8.32 & 0.08 & 0.54 \\
\hline $\mathrm{i}-\mathrm{C}_{4} \mathrm{H}_{8}$ & 0.04 & 0.30 & 0.00 & 0.00 & 0.00 & 0.00 & 0.00 & 0.00 \\
\hline trans-- $\mathrm{C}_{4} \mathrm{H}_{8}$ & 0.50 & 3.71 & 0.45 & 3.27 & 0.43 & 2.68 & 0.16 & 1.14 \\
\hline $\mathrm{cis}_{-} \mathrm{C}_{4} \mathrm{H}_{8}$ & 0.53 & 3.93 & 0.55 & 3.99 & 0.48 & 3.00 & 0.04 & 0.26 \\
\hline $1,3-\mathrm{C}_{4} \mathrm{H}_{6}$ & 0.00 & 0.00 & 0.00 & 0.00 & 0.00 & 0.00 & 0.00 & 0.00 \\
\hline $\mathrm{i}-\mathrm{C}_{5} \mathrm{H}_{12}$ & 0.01 & 0.06 & 0.00 & 0.00 & 0.00 & 0.00 & 0.00 & 0.00 \\
\hline $\mathrm{n}-\mathrm{C}_{5} \mathrm{H}_{12}$ & 0.62 & 4.60 & 0.65 & 4.72 & 0.57 & 3.51 & 0.63 & 4.35 \\
\hline $\mathrm{C}_{5+}$ & 2.35 & 17.3 & 2.21 & 16.0 & 2.26 & 14.0 & 0.86 & 5.97 \\
\hline
\end{tabular}

The data for $\mathrm{Cu}$ catalyst alcohol products is contained in Appendix V. The breakdown of the alcohol products is contained in Table 4.14 and Figure 4.8. Ma et al reported $^{22}$ that the change in $\mathrm{Cu}$ loading did not affect the alcohol selectivities significantly. This is seen in most cases; however, there is an uncharacteristically large amount of 1-pentanol being produced for the $0 \% \mathrm{Cu}$ catalyst. This is likely due to an error in the GC analysis. 


\begin{tabular}{|c|c|c|c|c|}
\hline \multicolumn{5}{|c|}{ Table 4.14: Aqueous Product Amounts for Catalysts of Varying Cu } \\
\hline \multirow{2}{*}{ Compound } & \multicolumn{4}{|c|}{ mmol } \\
\hline & $0 \% \mathrm{Cu}$ & $0.4 \% \mathrm{Cu}$ & $0.8 \% \mathrm{Cu}$ & $1.6 \% \mathrm{Cu}$ \\
\hline Methanol & 4.90 & 6.98 & 8.20 & 3.46 \\
\hline Ethanol & 6.42 & 8.27 & 11.25 & 4.21 \\
\hline 2-Propanol & 1.08 & 1.09 & 1.38 & 0.59 \\
\hline 1-Propanol & 2.45 & 2.09 & 4.38 & 1.15 \\
\hline 2-Butanol & 0.24 & 0.20 & 0.42 & 0.15 \\
\hline 1-Butanol & 1.92 & 1.54 & 2.64 & 1.05 \\
\hline 2-Pentanol & 0.00 & 0.00 & 0.01 & 0.00 \\
\hline 1-Pentanol & 4.16 & 0.51 & 1.20 & 0.55 \\
\hline Water & 14.35 & 21.07 & 30.53 & 9.46 \\
\hline
\end{tabular}

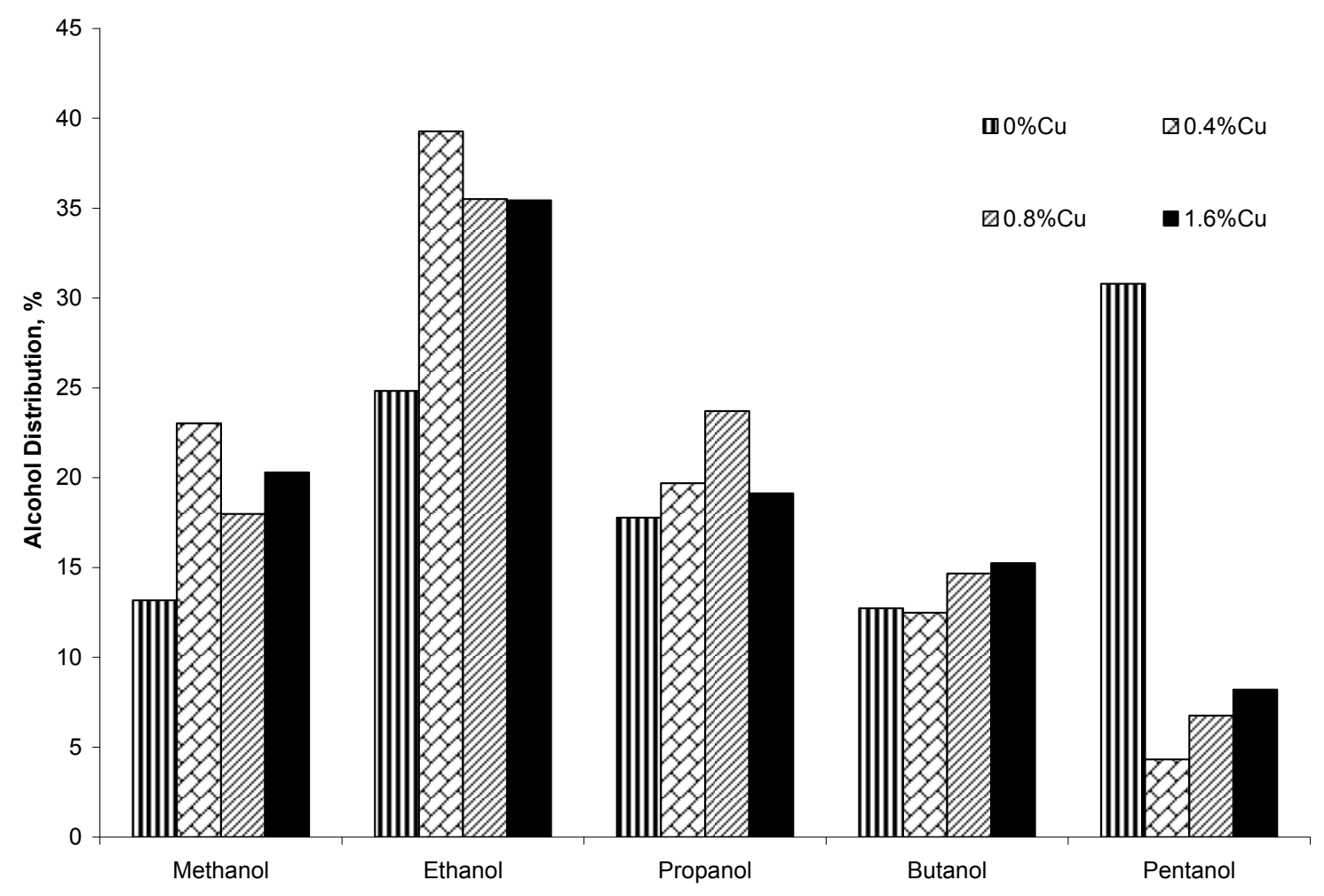

Figure 4.8: Alcohol Distribution for Catalysts of Varying Cu Content

Amounts of individual compounds found in the oil fraction of the liquid phase can be found in Appendix VI. Table 4.15 contains information on the lumped oil product distribution for the $\mathrm{Cu}$ catalysts. These numbers were not significantly affected by a change in $\mathrm{Cu}$ loading. This is consistent with the data reported by Ma et $\mathrm{al}^{22}$. Figure 4.9 contains selectivities for the oil phase according to carbon number. 


\begin{tabular}{|c|c|c|c|}
\hline \multicolumn{3}{|c|}{ Table 4.15: Lumped Oil Product Distribution for Varied Cu Catalysts } \\
\hline \multirow{2}{*}{ Catalysts } & \multicolumn{3}{|c|}{ Selectivity } \\
\cline { 2 - 4 } & $\mathrm{C}_{6}-\mathrm{C}_{8}$ & $\mathrm{C}_{9}-\mathrm{C}_{15}$ & $\mathrm{C}_{16+}$ \\
\hline $0 \% \mathrm{Cu}$ & 40.9 & 55.2 & 0.7 \\
\hline $0.4 \% \mathrm{Cu}$ & 38.0 & 58.6 & 3.4 \\
\hline $0.8 \% \mathrm{Cu}$ & 48.8 & 51.2 & 0.0 \\
\hline $1.6 \% \mathrm{Cu}$ & 47.2 & 50.0 & 2.6 \\
\hline
\end{tabular}

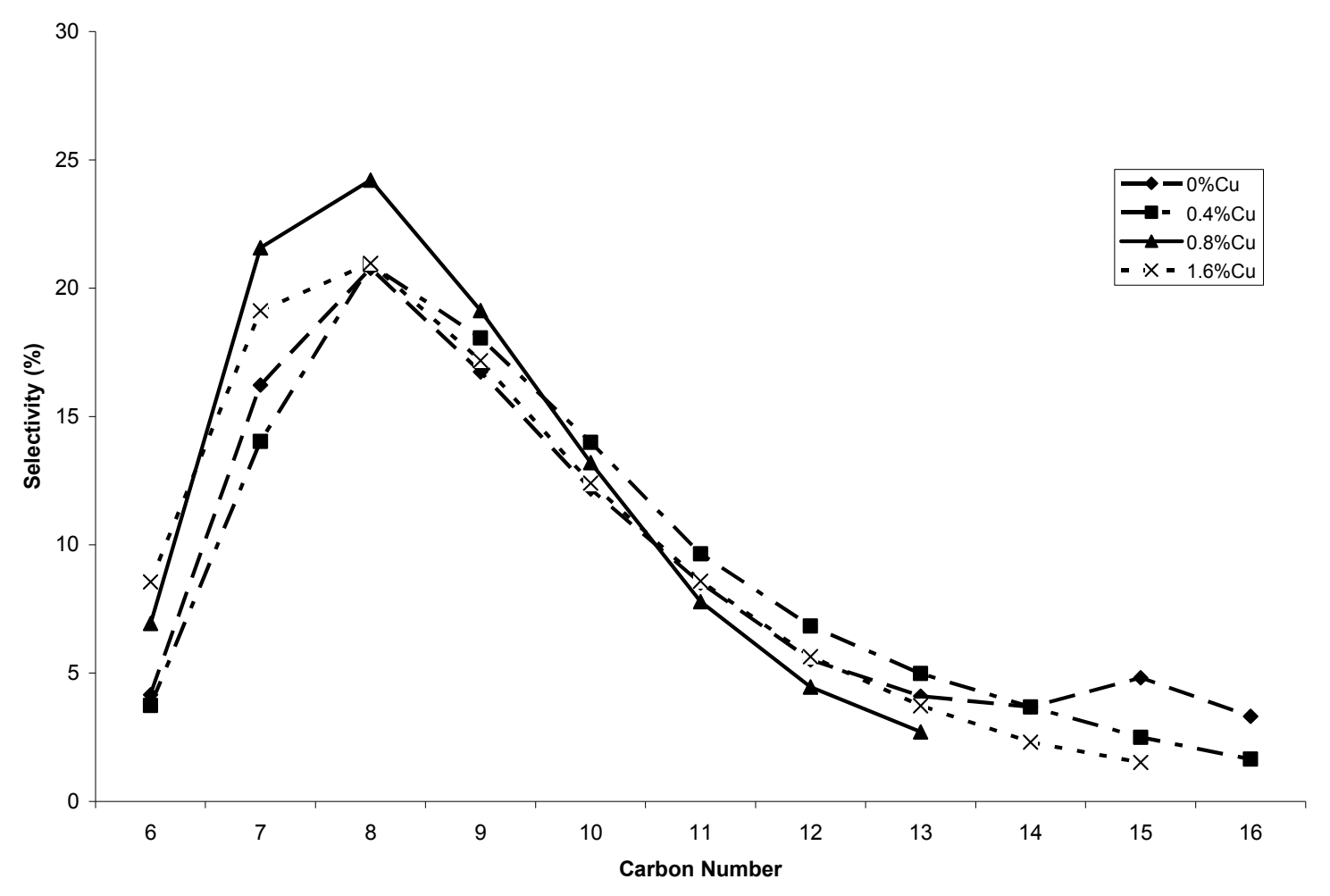

Figure 4.9: Oil Fraction Selectivity for Varying $\mathrm{Cu}$

The total liquid product properties overview is shown in Table 4.16. The oil products produced are comparable across all catalysts along with the olefin-to-paraffin ratio. Ma et $\mathrm{al}^{22}$ also reported similar olefin-to-paraffin ratios across all of the studied catalysts. The $0.8 \% \mathrm{Cu}$ catalyst produced the highest amount of alcohol product. 


\begin{tabular}{|c|c|c|c|c|c|c|}
\hline \multicolumn{6}{|c|}{ Table 4.16: Liquid Product Properties for Catalysts of Varying Cu Composition } \\
\hline Catalyst & $\begin{array}{c}\text { Total } \\
\text { Alcohol } \\
\text { Weight } \\
(\mathrm{mg})\end{array}$ & $\begin{array}{c}\text { Percent } \\
\text { Alcohol } \\
\text { in Water }\end{array}$ & $\begin{array}{c}\text { Total } \\
\text { Oil } \\
\text { Weight } \\
(\mathrm{mg})\end{array}$ & $\begin{array}{c}\text { Highest } \\
\text { Carbon } \\
\text { Number }\end{array}$ & $\frac{\text { Alcohols }}{\text { HCs }}(\%)$ & $\frac{\text { Olefins }}{\text { Paraffins }}(\%)$ \\
\hline $0 \% \mathrm{Cu}$ & 1192 & 88.3 & 900 & 18 & 132 & 18.5 \\
\hline $0.4 \% \mathrm{Cu}$ & 970 & 71.9 & 950 & 19 & 102 & 18.2 \\
\hline $0.8 \% \mathrm{Cu}$ & 1460 & 72.6 & 675 & 20 & 216 & 15.1 \\
\hline $1.6 \% \mathrm{Cu}$ & 547 & 76.3 & 970 & 18 & 56.4 & 15.3 \\
\hline
\end{tabular}

\subsection{Effect of Varying $K$}

Figure 4.10 shows the CO conversion for the catalysts studied. The conversion for the $0 \% \mathrm{~K}$ catalyst is very low compared to the other catalysts; however, the conversions for $\mathrm{K}$ greater than $0.45 \%$ are comparable. Table 4.17 shows the average conversion between 24-48 hours. This is consistent with data reported by Ma et $\mathrm{al}^{12}$ using simpler catalysts. Ma reported that small amounts of K can increase FTS activity while a large amount will decrease activity.

The selectivities of the gas phase components are contained in Table 4.18. For these, the $\mathrm{CO}_{2}$ selectivity rises significantly with increasing $\mathrm{K}$ loading while the $\mathrm{CH}_{4}$ selectivity decreases. This is consistent with data reported by Ma et $\mathrm{al}^{12}$ using catalysts containing only Fe and K. 


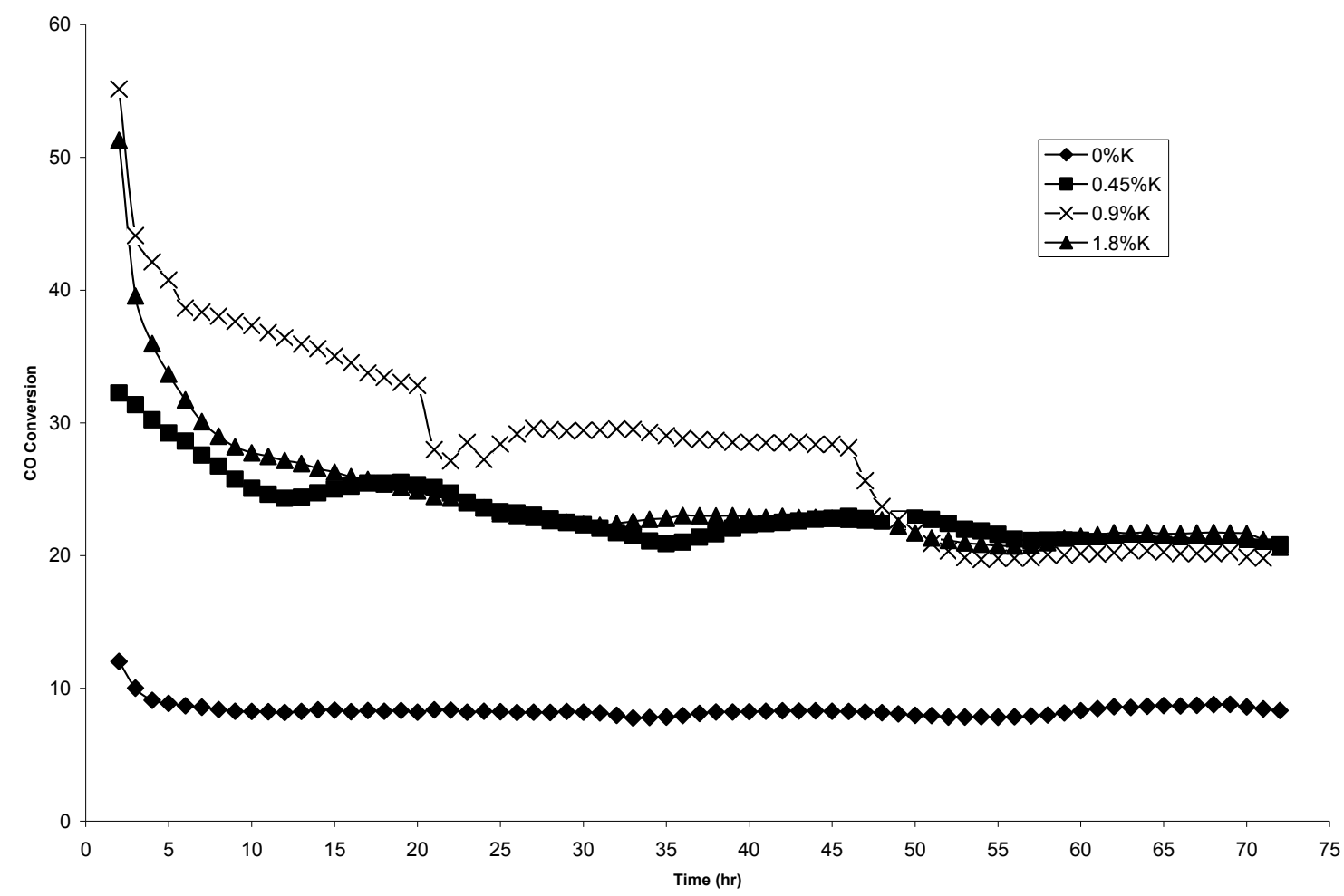

Figure 4.10: CO Conversion Comparison for Iron Catalysts of Varying K Composition

\begin{tabular}{|c|c|}
\hline & \\
\hline $0 \% \mathrm{~K}$ & ( \\
\hline $0.45 \% \mathrm{~K}$ & 22.3 \\
\hline $0.9 \% \mathrm{~K}$ & 28.5 \\
\hline $1.8 \% \mathrm{~K}$ & 22.8 \\
\hline
\end{tabular}




\begin{tabular}{|c|c|c|c|c|c|c|c|c|}
\hline \multicolumn{7}{|c|}{ Table 4.18: Average Gas Phase Component Selectivities and Amounts (mmols) for } \\
\hline \multirow{2}{*}{ Compound } & \multicolumn{2}{|c}{$0 \% \mathrm{~K}$} & \multicolumn{2}{c|}{$0.45 \% \mathrm{~K}$} & \multicolumn{2}{c|}{$0.9 \% \mathrm{~K}$} & \multicolumn{2}{c|}{$1.8 \% \mathrm{~K}$} \\
\cline { 2 - 10 } & Select & Amount & Select & Amount & Select & Amount & Select & Amount \\
\hline $\mathrm{CO}_{2}$ & 43.5 & 94.6 & 60.6 & 305 & 69.64 & 432 & 82.0 & 352 \\
\hline $\mathrm{CH}_{4}$ & 30.6 & 66.6 & 18.4 & 92.8 & 12.86 & 79.8 & 7.90 & 34.0 \\
\hline $\mathrm{C}_{2} \mathrm{H}_{6} / \mathrm{C}_{2} \mathrm{H}_{4}$ & 12.1 & 26.3 & 7.57 & 38.2 & 6.14 & 38.1 & 3.99 & 17.2 \\
\hline $\mathrm{C}_{3} \mathrm{H}_{8}$ & 5.98 & 13.0 & 2.58 & 13.0 & 1.17 & 7.27 & 0.45 & 1.95 \\
\hline $\mathrm{C}_{3} \mathrm{H}_{6}$ & 1.92 & 4.17 & 4.10 & 20.7 & 4.45 & 27.6 & 2.50 & 10.8 \\
\hline $\mathrm{i}-\mathrm{C}_{4} \mathrm{H}_{10}$ & 0.15 & 0.33 & 0.06 & 0.30 & 0.04 & 0.24 & 0.00 & 0.00 \\
\hline $\mathrm{n}-\mathrm{C}_{4} \mathrm{H}_{10}$ & 2.00 & 4.34 & 1.09 & 5.51 & 0.62 & 3.84 & 0.24 & 1.01 \\
\hline $1-\mathrm{C}_{4} \mathrm{H}_{8}$ & 0.16 & 0.35 & 0.64 & 3.23 & 1.34 & 8.32 & 1.29 & 5.52 \\
\hline $\mathrm{i}-\mathrm{C}_{4} \mathrm{H}_{8}$ & 0.00 & 0.00 & 0.00 & 0.00 & 0.00 & 0.00 & 0.00 & 0.00 \\
\hline trans- $\mathrm{C}_{4} \mathrm{H}_{8}$ & 0.34 & 0.74 & 0.80 & 4.05 & 0.43 & 2.68 & 0.00 & 0.00 \\
\hline${\text { cis- }-\mathrm{C}_{4} \mathrm{H}_{8}}^{2}$ & 0.08 & 0.17 & 0.66 & 3.32 & 0.48 & 3.00 & 0.00 & 0.00 \\
\hline $1,3-\mathrm{C}_{4} \mathrm{H}_{6}$ & 0.00 & 0.00 & 0.00 & 0.00 & 0.00 & 0.00 & 0.00 & 0.00 \\
\hline $\mathrm{i}-\mathrm{C}_{5} \mathrm{H}_{12}$ & 0.00 & 0.00 & 0.00 & 0.00 & 0.00 & 0.00 & 0.00 & 0.00 \\
\hline $\mathrm{n}-\mathrm{C}_{5} \mathrm{H}_{12}$ & 1.30 & 2.83 & 0.97 & 4.88 & 0.57 & 3.51 & 0.01 & 0.03 \\
\hline $\mathrm{C}_{5+}$ & 1.79 & 3.88 & 2.51 & 12.6 & 2.26 & 14.0 & 1.63 & 7.00 \\
\hline
\end{tabular}

Appendix VII contains alcohol data for K catalysts. Table 4.19 and Figure 4.11 show more information on the alcohol phase of the liquid products. The $0 \% \mathrm{~K}$ catalyst is the only catalyst to produce more methanol than ethanol. For the $0.9 \% \mathrm{~K}$ (base) catalyst, methanol production decreases while $\mathrm{C}_{3+}$ alcohol production increases in relation to the other $\mathrm{K}$ catalysts. This is inconsistent with results reported by $\mathrm{Ma}^{12}$ as he produced oxygenates with all studied catalysts. It is possible that the higher $\mathrm{K}$ content in the $1.8 \% \mathrm{~K}$ catalyst caused a higher WGS rate causing no water to be collected and the aqueous product was left undetectable in the gas- or oil-phase. 


\begin{tabular}{|c|c|c|c|c|}
\hline \multicolumn{5}{|c|}{ Table 4.19: Aqueous Product Amounts for Catalysts of Varying K } \\
\hline \multirow{2}{*}{ Compound } & \multicolumn{4}{|c|}{ mmol } \\
\hline & $0 \% \mathrm{~K}$ & $0.45 \% \mathrm{~K}$ & $0.9 \% \mathrm{~K}$ & $1.8 \% \mathrm{~K}$ \\
\hline Methanol & 3.89 & 1.42 & 8.20 & 0.00 \\
\hline Ethanol & 1.75 & 1.09 & 11.25 & 0.00 \\
\hline 2-Propanol & 0.05 & 0.09 & 1.38 & 0.00 \\
\hline 1-Propanol & 0.32 & 0.13 & 4.38 & 0.00 \\
\hline 2-Butanol & 0.01 & 0.02 & 0.42 & 0.00 \\
\hline 1-Butanol & 0.12 & 0.13 & 2.64 & 0.00 \\
\hline 2-Pentanol & 0.00 & 0.00 & 0.01 & 0.00 \\
\hline 1-Pentanol & 0.03 & 0.03 & 1.20 & 0.00 \\
\hline Water & 55.56 & 105.92 & 30.53 & 0.00 \\
\hline
\end{tabular}

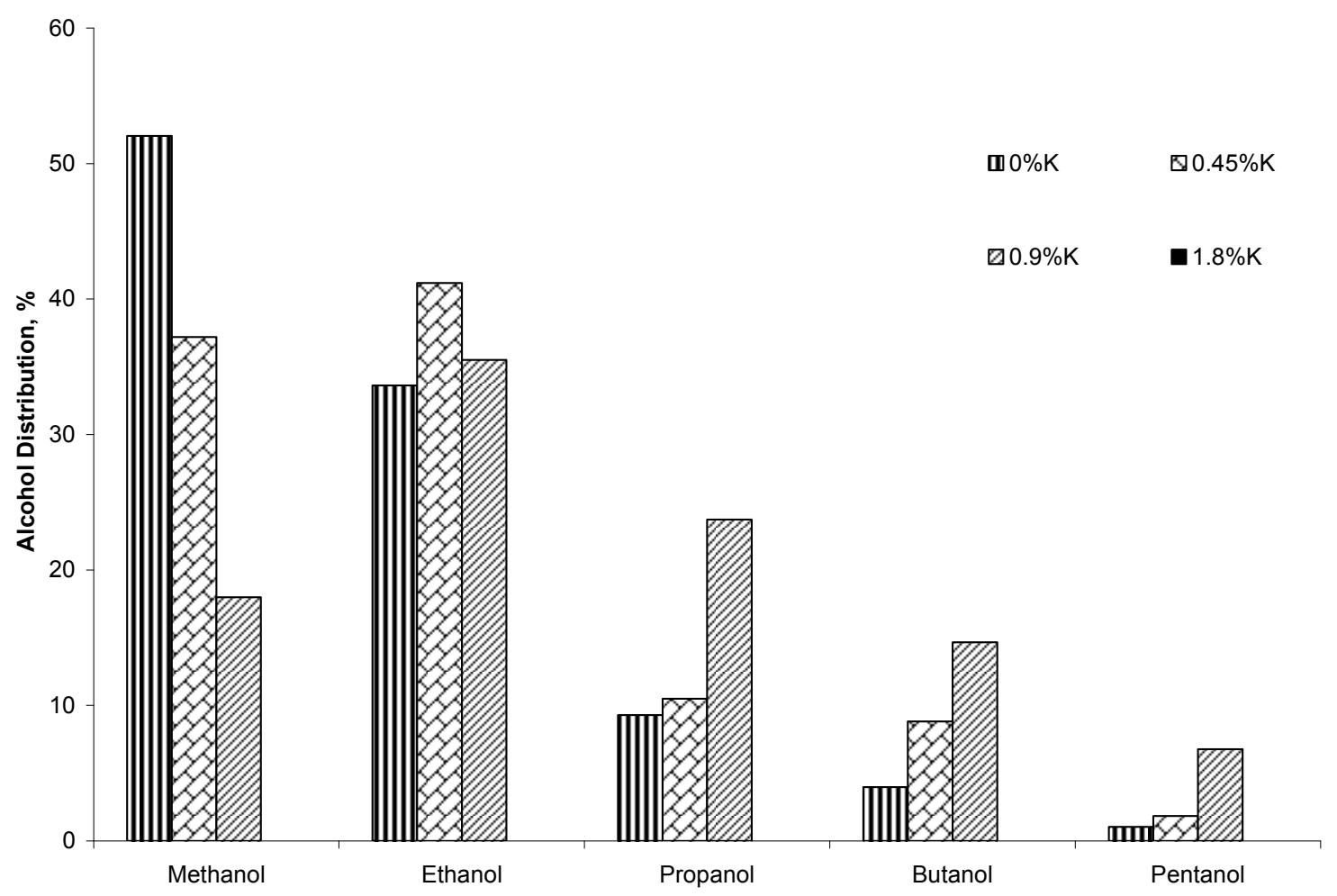

Figure 4.11: Alcohol Distribution for Catalysts of Varying K Content

Detailed information on the individual compounds in the oil fraction of the liquid phase can be found in Appendix VIII. Table 4.20 shows the lumped distribution of the oil phase liquid products. These results are not consistent with those reported by $\mathrm{Ma}^{12}$. Ma reported an oil fraction for all catalysts studied. Here, an oil fraction was not observed for the $0 \% \mathrm{~K}$ catalyst. Figure 4.12 contains data on the oil fraction selectivities by carbon number. 


\begin{tabular}{|c|c|c|c|}
\hline \multirow{2}{*}{ Table 4.20: Lumped Oil Product Distribution for Varied K Catalysts } \\
\hline \multirow{2}{*}{ Catalysts } & \multicolumn{3}{|c|}{ Selectivity } \\
\cline { 2 - 4 } & $\mathrm{C}_{6}-\mathrm{C}_{8}$ & $\mathrm{C}_{9}-\mathrm{C}_{15}$ & $\mathrm{C}_{16+}$ \\
\hline $0 \% \mathrm{~K}$ & 0.0 & 0.0 & 0.0 \\
\hline $0.45 \% \mathrm{~K}$ & 40.7 & 59.3 & 0.0 \\
\hline $0.9 \% \mathrm{~K}$ & 48.8 & 51.2 & 0.0 \\
\hline $1.8 \% \mathrm{~K}$ & 34.1 & 58.2 & 7.8 \\
\hline
\end{tabular}

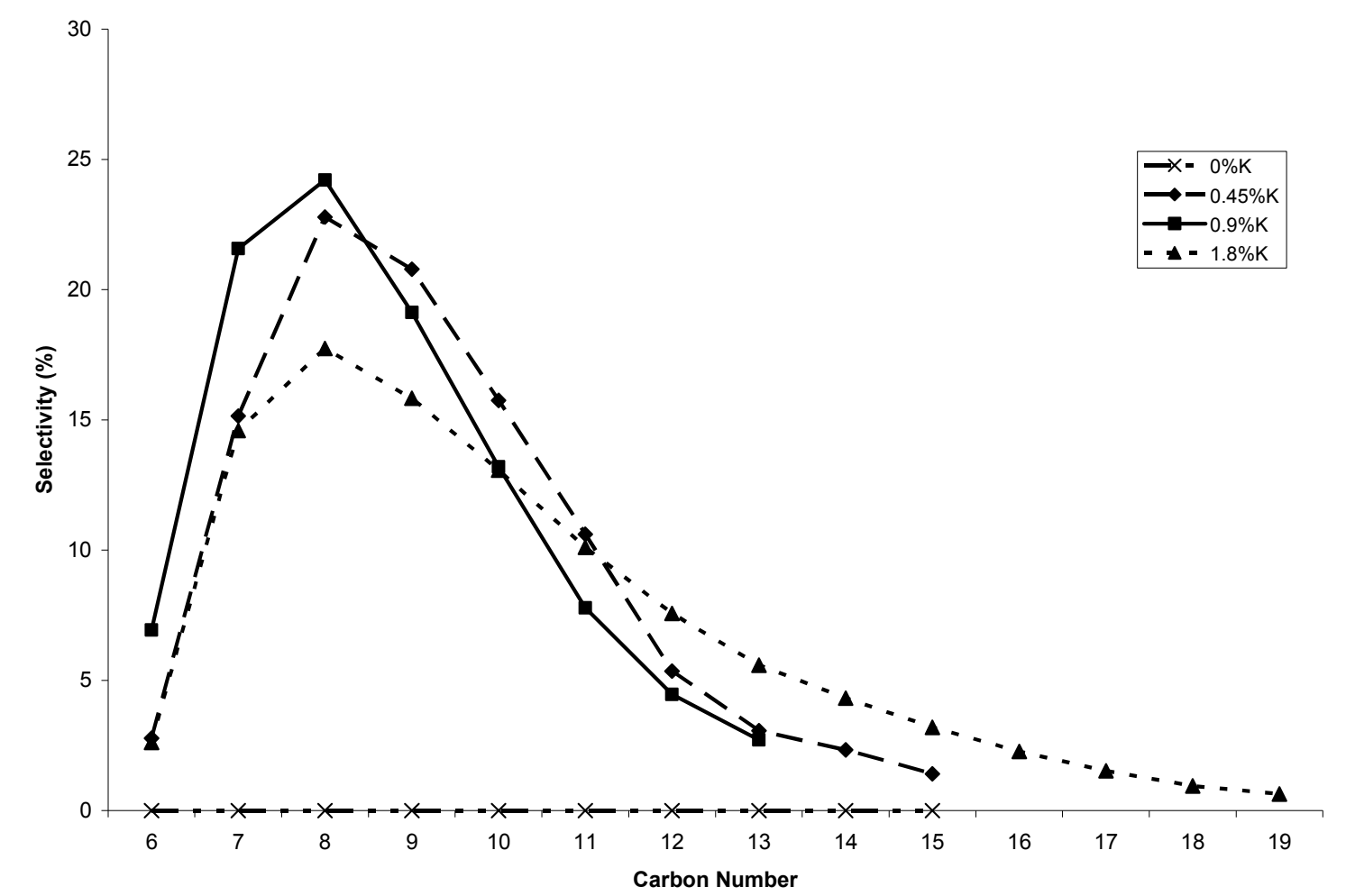

Figure 4.12: Oil Fraction Selectivity for Varying K

Table 4.21 contains the liquid product properties. Two interesting things happen with these catalysts. The $0 \% \mathrm{~K}$ catalyst produces no detectable oil while the $1.8 \% \mathrm{~K}$ catalyst produces no detectable alcohol. The $1.8 \% \mathrm{~K}$ catalyst also has a very high olefinto-paraffin ratio. Ma et al reported ${ }^{12}$ that the olefin-to-paraffin ratio had a large increase with the addition of $0.9 \% \mathrm{~K}$. Here, the large increase is not seen until the addition of $1.8 \% \mathrm{~K}$. 


\begin{tabular}{|l|c|c|c|c|c|c|}
\hline \multicolumn{7}{|c|}{ Table 4.21: Liquid Product Properties for Catalysts of Varying K Composition } \\
\hline Catalyst & $\begin{array}{c}\text { Total } \\
\text { Alcohol } \\
\text { Weight } \\
(\mathrm{mg})\end{array}$ & $\begin{array}{c}\text { Percent } \\
\text { Alcohol } \\
\text { in Water }\end{array}$ & $\begin{array}{c}\text { Total } \\
\text { Oil } \\
\text { Weight } \\
(\mathrm{mg})\end{array}$ & $\begin{array}{c}\text { Highest } \\
\text { Carbon } \\
\text { Number }\end{array}$ & $\frac{\text { Alcohols }}{\text { HCs }}(\%)$ & $\frac{\text { Olefins }}{\text { Paraffins }}(\%)$ \\
\hline $0 \% \mathrm{~K}$ & 239 & 19.3 & 0 & 0 & - & 0.0 \\
\hline $0.45 \% \mathrm{~K}$ & 122 & 6.0 & 400 & 15 & 30.5 & 21.5 \\
\hline $0.9 \% \mathrm{~K}$ & 1460 & 72.6 & 675 & 20 & 216 & 15.1 \\
\hline $1.8 \% \mathrm{~K}$ & 0 & 0.0 & 2210 & 26 & 0.0 & 71.4 \\
\hline
\end{tabular}

\subsection{Data Analysis by Regression}

In an attempt to understand better the large amount of data obtained over the course of this project, a regression model was employed for conversion, oil yield, olefinto-paraffin ratio, gasoline yield and diesel yield. A regression model is defined ${ }^{23}$ as "a mathematical expression that can quantitatively describe the variability among the observations, or responses, by partitioning an observation into two parts. The first part of the decomposition incorporates everything known about the magnitude of a response; the remaining portion is residual”.

The equation that was fit is as follows:

$$
\begin{aligned}
& \mathrm{Y}=\mathrm{A}_{0}+\mathrm{A}_{1} \mathrm{Fe}+\mathrm{A}_{2} \mathrm{Mo}+\mathrm{A}_{3} \mathrm{Cu}+\mathrm{A}_{4} \mathrm{~K}+\mathrm{A}_{5} \mathrm{FeMo}+ \\
& \mathrm{A}_{6} \mathrm{FeCu}+\mathrm{A}_{7} \mathrm{FeK}+\mathrm{A}_{8} \mathrm{MoCu}+\mathrm{A}_{9} \mathrm{MoK}+\mathrm{A}_{10} \mathrm{CuK}+ \\
& \mathrm{A}_{11} \mathrm{FeMoCu}+\mathrm{A}_{12} \mathrm{FeMoK}+\mathrm{A}_{13} \mathrm{FeCuK}+\mathrm{A}_{14} \mathrm{MoCuK}+ \\
& \mathrm{A}_{15} \mathrm{FeMoCuK}+\mathrm{A}_{16} \mathrm{Fe}^{2}+\mathrm{A}_{17} \mathrm{Mo}^{2}+\mathrm{A}_{18} \mathrm{Cu}^{2}+\mathrm{A}_{19} \mathrm{~K}^{2}
\end{aligned}
$$

The left side of the equation contains the dependent variable (i.e. conversion or oil yield). The right side of the equation contains the independent variables (i.e. the catalyst promoters) and the unknown coefficients. 
To avoid statistical bias, the independent variables were normalized such that the base case values were set to 1 . The equations used to normalize the variables are as follows:

$$
\begin{aligned}
& M o_{N}=\frac{M o}{6} \\
& F e_{N}=\frac{F e}{16} \\
& C u_{N}=\frac{C u}{0.8} \\
& K_{N}=\frac{K}{0.9}
\end{aligned}
$$

The regression calculations were performed by a program called Minitab. This program performs a stepwise regression by backwards elimination. This process deletes terms deemed statistically insignificant as decided by the F-value. The F-value is a signal-to-noise ratio, and is defined:

$$
F=\left(\frac{A_{i}}{S_{A_{i}}}\right)^{2}
$$

In other words, $F$ is the square of the coefficient from the model $\left(A_{i}\right)$ divided by the standard deviation of that term $\left(\mathrm{S}_{\mathrm{Ai}}\right)$. The standard deviation is defined as:

$$
S_{A_{i}}=\sqrt{\frac{\sum_{n}\left(y-y_{p}\right)^{2}}{(n-k-1) \sum_{n}\left(x_{i}-x_{A_{i}}\right)^{2}}}
$$

where $y$ is the observed value for the dependent variable $\mathrm{y}_{\mathrm{p}}$ is the predicted value for the dependent variable $\mathrm{n}$ is the number of data points 
$\mathrm{k}$ is the number of coefficients

$\mathrm{x}_{\mathrm{i}}$ is the value for the independent variable for the $\mathrm{i}$-th parameter

$\mathrm{x}_{\mathrm{Ai}}$ is the average value for the independent variable for the $\mathrm{i}$-th parameter

The coefficient of determination $\left(\mathrm{R}^{2}\right)$ is an indication of how well the equation fits the data. $\mathrm{R}^{2}$ is between 0 and 1 and is defined:

$$
R^{2}=\frac{\sum_{n}\left(y-y_{A}\right)^{2}-\sum_{n}\left(y-y_{p}\right)^{2}}{\sum_{n}\left(y-y_{A}\right)^{2}}
$$

where $\mathrm{y}_{\mathrm{A}}$ is the average value for $\mathrm{y}$

For CO conversion, the equation was determined to be:

$$
\text { Conv }=31.65+10.1 \mathrm{Fe}_{\mathrm{N}}{ }^{2}-15.7 \mathrm{Mo}_{\mathrm{N}}
$$

This gives the conversion in units of percent. This indicated that Fe and Mo are the most important terms, with increasing Mo decreasing conversion.

For oil fraction yield, the equation was determined to be:

$$
\text { Oil }=3268-4436 \mathrm{Mo}_{\mathrm{N}}+920 \mathrm{Fe}_{\mathrm{N}} \mathrm{Mo}_{\mathrm{N}} \mathrm{K}_{\mathrm{N}}+1083 \mathrm{Mo}_{\mathrm{N}}{ }^{2}
$$

This gives the oil fraction yield in units of mg. This indicates that the most important terms are Mo and an interaction between Fe, Mo and K.

For the hydrocarbon production rate, the equation was determined to be:

$$
\text { Hydro }=126.68+304 \mathrm{Fe}_{\mathrm{N}}-163 \mathrm{Mo}_{\mathrm{N}}
$$

This gives the production rate of hydrocarbons in units of $\mathrm{g} / \mathrm{kg}$-cat $/ \mathrm{h}$. It depends positively on Fe and negatively on Mo.

For the Olefin-to-Paraffin ratio, the equation was determined to be:

$$
\mathrm{O} / \mathrm{P}=0.302+0.165 \mathrm{~K}_{\mathrm{N}}^{2}-0.276 \mathrm{Mo}_{\mathrm{N}}
$$


This gives the olefin-to-paraffin ratio as a unitless number. This indicates that $\mathrm{K}$ causes an increase in the olefin-to-paraffin ratio and Mo causes a decrease.

For the gasoline range production, the equation was determined to be:

$$
\text { Gasoline }=36.42+30 \mathrm{Fe}_{\mathrm{N}} \mathrm{K}_{\mathrm{N}}
$$

This gives the gasoline range production as a percentage. This indicates that an interaction between Fe and $\mathrm{K}$ is important to the production of gasoline range products. For the diesel range production, the equation was determined to be:

$$
\text { Diesel }=65.58+29.5 \mathrm{Fe}_{N} \mathrm{Cu}_{N} \mathrm{~K}_{N}-31 \mathrm{Mo}_{\mathrm{N}} \mathrm{Cu}_{N}
$$

This gives the diesel range production as a percentage. This indicates that an interaction between $\mathrm{Fe}, \mathrm{Cu}$ and $\mathrm{K}$ is important to diesel range production along with an interaction between $\mathrm{Mo}$ and $\mathrm{Cu}$.

Table 4.18 contains $\mathrm{R}^{2}$ values for the previous equations.

\begin{tabular}{|l|r|}
\hline \multicolumn{2}{|c|}{ Table 4.22: $\mathrm{R}^{2}$ Values for the Regression Models } \\
\hline \multicolumn{1}{|c|}{ Equation Number } & $\mathrm{R}^{2}$ Value \\
\hline 4.9 (Conversion) & 0.65 \\
\hline 4.10 (Oil production) & 0.87 \\
\hline 4.11 (Hydrocarbon production) & 0.81 \\
\hline 4.12 (O/P) & 0.81 \\
\hline 4.13 (Gasoline range) & 0.37 \\
\hline 4.14 (Diesel range) & 0.58 \\
\hline
\end{tabular}

This indicates that the equation for oil fraction yield and olefin-to-paraffin ratio is a good fit for the data. However, the gasoline range production has a very low $\mathrm{R}^{2}$ value. So this relationship is less certain than the others. In any case, these equations can be used to formulate multi-component Fe-based catalysts appropriately, depending on what parameter is to be optimized. 


\subsection{Characterization of the Catalyst}

Table 4.19 shows BET data for the base case catalyst before and after reaction. As expected, the values of the fresh catalyst decrease from the pre-impregnated support values in Table 3.1 and decrease still in the spent catalyst.

\begin{tabular}{|l|c|c|c|}
\hline \multicolumn{4}{|c|}{ Table 4.23: BET Properties for Base Case Catalyst } \\
\hline Catalyst & $\begin{array}{c}\text { BET Surface Area } \\
\left(\mathrm{m}^{2} / \mathrm{g}\right)\end{array}$ & $\begin{array}{c}\text { Large-Pore Surface } \\
\text { Area }\left(\mathrm{m}^{2} / \mathrm{g}\right)\end{array}$ & $\begin{array}{c}\text { Macropore Volume } \\
>2.0 \mathrm{~nm}\left(\mathrm{~cm}^{3} / \mathrm{g}\right)\end{array}$ \\
\hline Fresh & 619.5 & 142.8 & 0.07 \\
\hline Spent & 266.1 & 109.3 & 0.05 \\
\hline
\end{tabular}

Figure 4.13 shows the XRD pattern for the base case catalyst before reaction. The two phases identifiable are the graphite from the support and magnetite, $\mathrm{Fe}_{3} \mathrm{O}_{4}$. The reason $\mathrm{Cu}$ and $\mathrm{K}$ are not visible in the $\mathrm{XRD}$ pattern is due to the low concentrations of both in the catalyst. Mo is not seen because Mo deposits as small particles and does not typically reduce until around $700^{\circ} \mathrm{C}$ as can been seen in the TPR data.

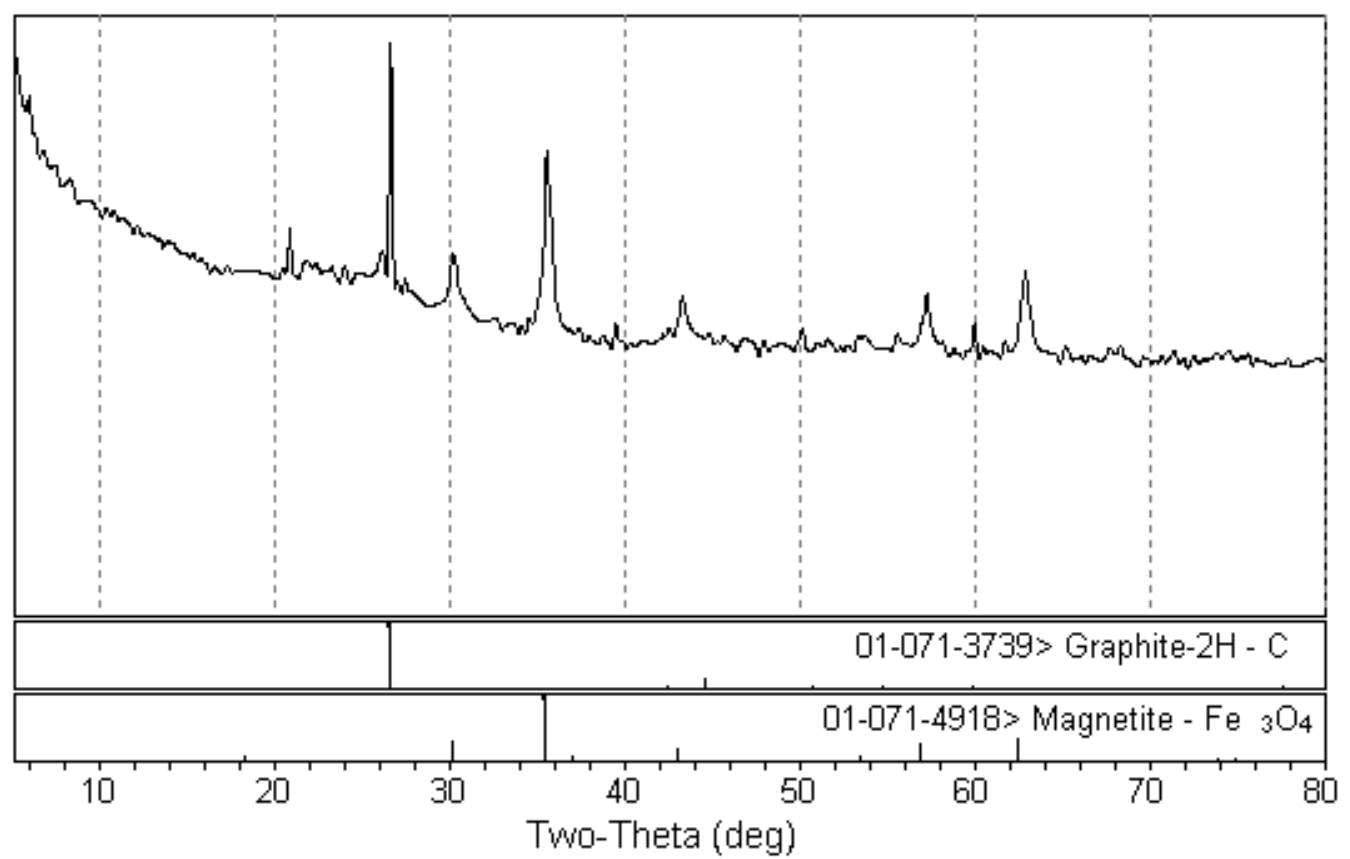

Figure 4.13: XRD Pattern for Base Case Catalyst Before Reaction 
Figure 4.14 shows the XRD pattern of the base case catalyst after reaction has taken place. The two phases that can be indentified are graphite from the support and $\mathrm{Fe}_{2} \mathrm{C}$. Iron carbides are considered the active phase for iron catalysts. It is possible that there was metallic iron present; however, the sample was exposed to air after reaction so any metallic iron would have been oxidized.

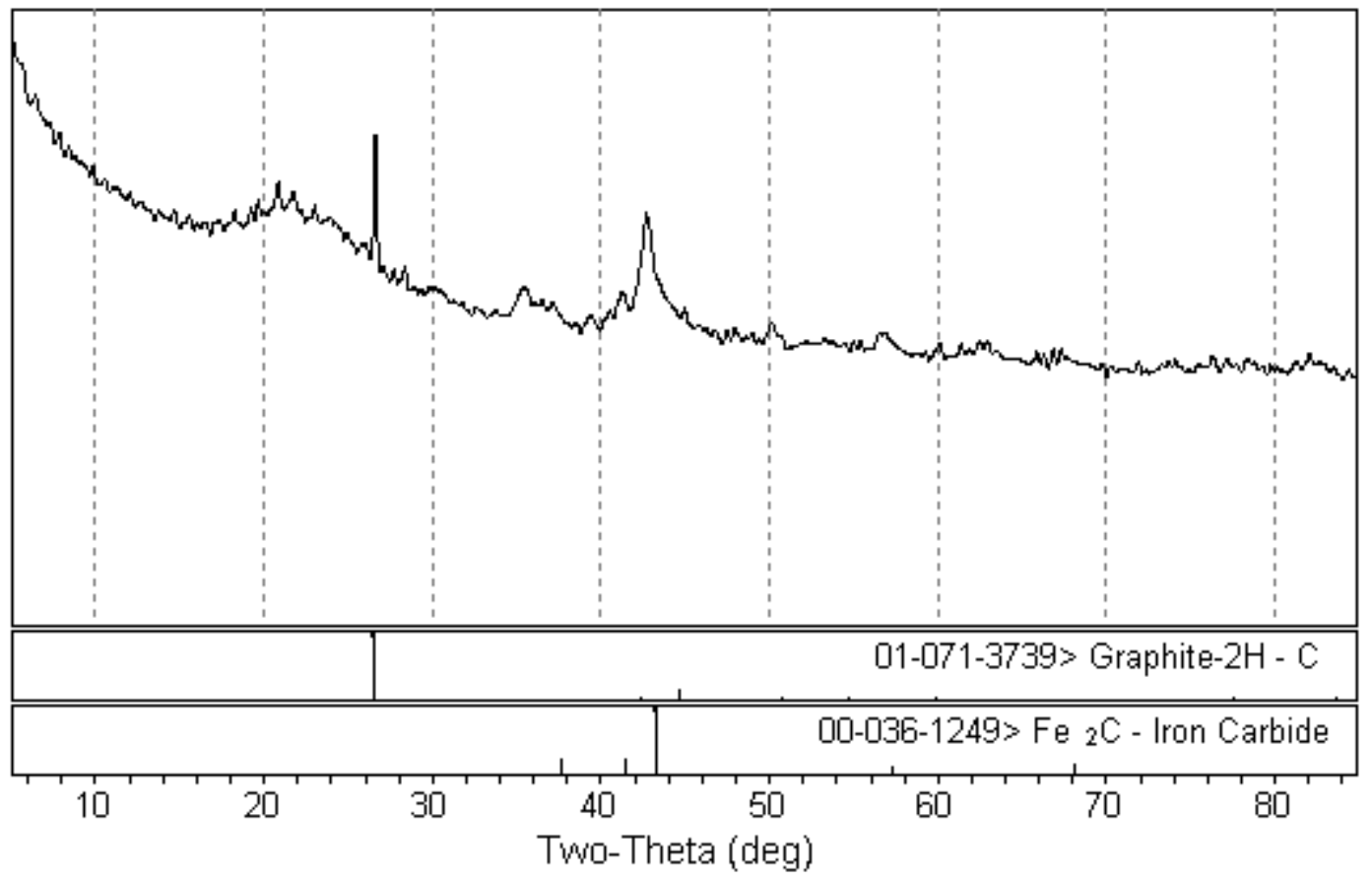

Figure 4.14: XRD Pattern for Base Case Catalyst After Reaction

Figure 4.15 shows TPR data for four different iron catalysts $(0 \%, 8 \%, 16 \%$ and 32). According to $\mathrm{Ma}$ et $\mathrm{al}^{24}$, from $250-550^{\circ} \mathrm{C}, \alpha \mathrm{Fe}_{2} \mathrm{O}_{3}$ is being reduced to $\mathrm{Fe}_{3} \mathrm{O}_{4}$ then $\mathrm{Fe}_{3} \mathrm{O}_{4}$ is being reduced to $\mathrm{FeO}$. In the range of $400-700^{\circ} \mathrm{C}$, there is a broad peak showing that $\mathrm{FeO}$ is being reduced to $\mathrm{Fe}$ metal. In the $0 \% \mathrm{Fe}$ case, a negative peak is seen around $700^{\circ} \mathrm{C}$, this is attributed to $\mathrm{MoO}_{2}$ being reduced to MoC. The reason the peak is negative is due to a release of $\mathrm{CO}_{2}$ during the reduction. 


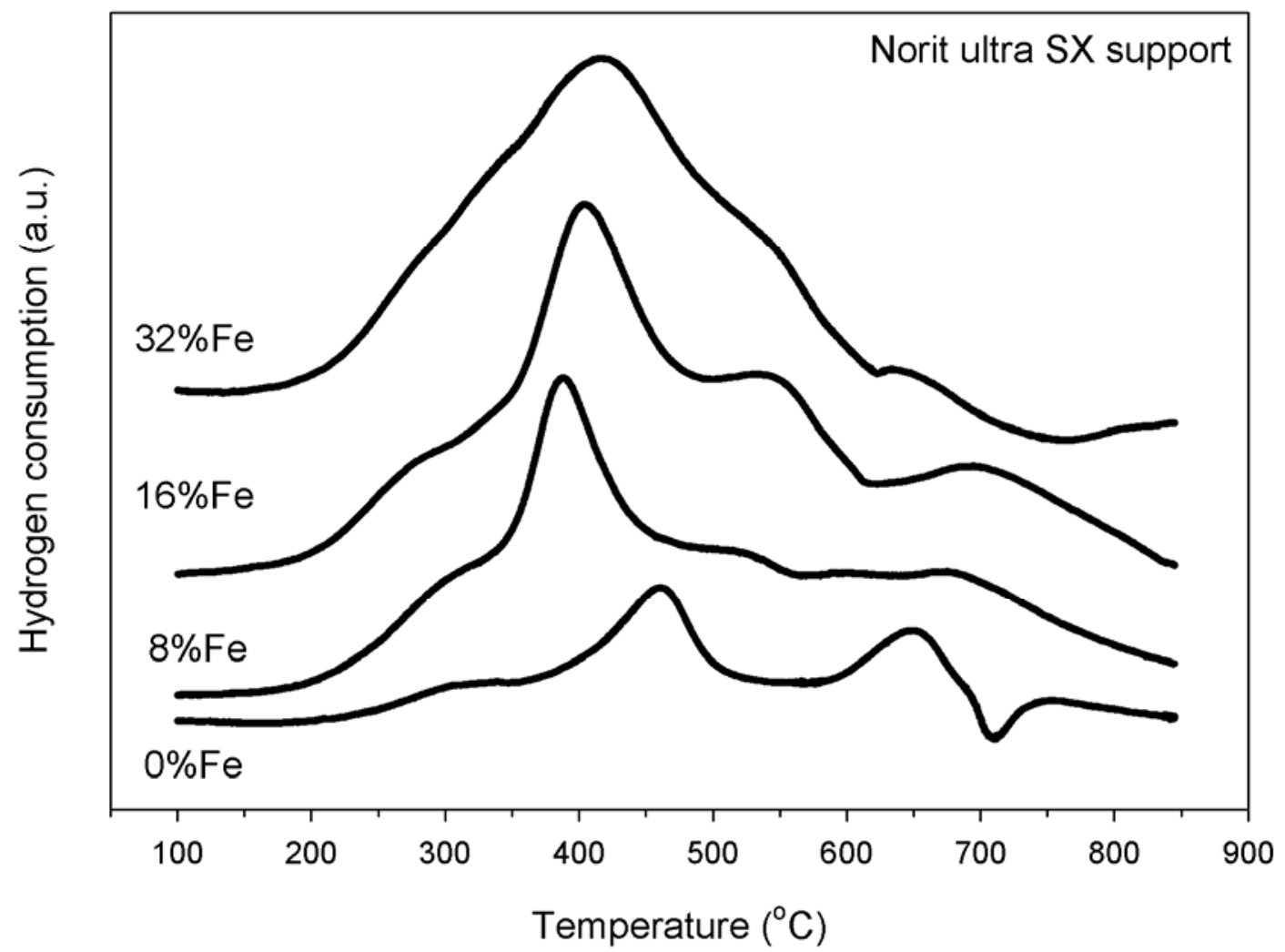

Figure 4.15: TPR Data for Varied Fe Catalysts

Table 4.24 contains the information on the $\mathrm{H}_{2}$ uptake calculated from the TPR curves. This was done by integrating the area between $200-800^{\circ} \mathrm{C}$ as a single peak. From this, the degree of reduction was calculated. This was done by assuming that the $\mathrm{Fe}$ reduced by the following equation:

$$
\mathrm{Fe}_{2} \mathrm{O}_{3}+3 \mathrm{H}_{2} \rightarrow 2 \mathrm{Fe}+3 \mathrm{H}_{2} \mathrm{O}
$$

Then to discount the effect of the support and the other metals, the $\mathrm{H}_{2}$ consumption of the $0 \% \mathrm{Fe}$ catalyst was subtracted from the others. The degree of reduction is shown in Table 4.25. It is seen that the degree of reduction decreases as the metal concentration increases. This is likely due to less metal being exposed on the surface when present in higher concentrations. 


\begin{tabular}{|r|r|}
\hline \multicolumn{2}{|c|}{ Table 4.24: $\mathrm{H}_{2}$ Consumption for Varying Fe Catalysts } \\
\hline Catalyst & $\mathrm{H}_{2}$ Consumption $(\mu \mathrm{mol} / \mathrm{g})$ \\
\hline $0 \% \mathrm{Fe}$ & 498 \\
\hline $8 \% \mathrm{Fe}$ & 1068 \\
\hline $16 \% \mathrm{Fe}$ & 1353 \\
\hline $32 \% \mathrm{Fe}$ & 1427 \\
\hline
\end{tabular}

\begin{tabular}{|r|r|r|}
\hline \multicolumn{3}{|c|}{ Table 4.25: Degree of Reduction for Varying Fe Catalysts } \\
\hline Catalyst & \multicolumn{1}{|c|}{$\mathrm{H}_{2}$ Consumption $(\mu \mathrm{mol} / \mathrm{g})$} & Degree of Reduction (\%) \\
\hline $0 \% \mathrm{Fe}$ & 0 & 0 \\
\hline $8 \% \mathrm{Fe}$ & 570 & 27.1 \\
\hline $16 \% \mathrm{Fe}$ & 855 & 19.7 \\
\hline $32 \% \mathrm{Fe}$ & 929 & 10.9 \\
\hline
\end{tabular}

\subsection{Summary}

The effects that four components, $\mathrm{Mo}, \mathrm{Fe}, \mathrm{Cu}$ and $\mathrm{K}$, had on a catalyst were studied. The parameters looked at were the effects on gas-phase products, oil-phase products and aqueous-phase products. The data were compared to similar catalysts studied previously by Ma. In particular, the effects of $\mathrm{K}$ were compared to catalysts studied by Ma that contained only $\mathrm{Fe}$ and $\mathrm{K}$. The effects of $\mathrm{Cu}$ were compared to catalysts studied by Ma that contained only $\mathrm{Fe}, \mathrm{Cu}$ and $\mathrm{K}$. The effects of Mo were compared to catalysts studied by Ma that contained Mo, Fe, $\mathrm{Cu}$ and $\mathrm{K}$. The effect of $\mathrm{Fe}$ was never studied by Ma. 


\section{Chapter 5}

\section{Conclusions and Future Work}

\subsection{Conclusions}

The conclusions that can be drawn on the data obtained are as follows.

1. Adding Mo to the catalyst generally lowers the CO conversion, but causes an increase in stability. This is consistent with results reported by Ma using catalysts containing $\mathrm{Mo}, \mathrm{Fe}, \mathrm{Cu}$ and $\mathrm{K}$. Adding Mo also lowers the production of $\mathrm{CO}_{2}$ and increases $\mathrm{CH}_{4}$ production. This is consistent with results reported by Ma. The addition of Mo increases aqueous production up to a loading of $6 \%$ and then the aqueous production decreases at $12 \%$ loading. This is consistent with results reported by Ma. An increase in Mo loading causes a decrease in total oil production as well as the olefin-to-paraffin ratio. This is inconsistent with Ma. He reported similar ratios across catalysts containing 0-12\%Mo.

2. Adding Fe to the catalysts causes an increase in CO conversion. Adding Fe also causes an increase in $\mathrm{CO}_{2}$ production and a decrease in $\mathrm{CH}_{4}$ production. Changing the Fe loading of the catalyst had a small effect on aqueous production while the oil production increased with increasing Fe loading.

3. Changes in $\mathrm{Cu}$ loading had very small effects on all parameters. This is consistent with data reported by Ma using simpler catalysts, catalysts containing only $\mathrm{Fe}, \mathrm{Cu}$ and $\mathrm{K}$.

4. The absence of $\mathrm{K}$ causes a very low $\mathrm{CO}$ conversion while all other $\mathrm{K}$ loadings studied have comparable CO conversions. This is consistent with reports by Ma 
using simpler catalysts, catalysts containing only Fe and $\mathrm{K}$. Increases in K loading causes an increase in $\mathrm{CO}_{2}$ production and a decrease in $\mathrm{CH}_{4}$ production. This is consistent with reports by Ma using simpler catalyst. Increases in $\mathrm{K}$ loading caused an increase in oil production.

5. The regression equations for the olefin-to-paraffin ratio and the oil fraction yield gave a well-fitted equation while the gasoline production gave an equation that did not fit very well.

\subsection{Recommendations for Future Work}

Based on the data, these are recommendations for future work in the area.

1. The effect of varying multiple promoters at once should be investigated.

2. The effect of varying reaction conditions (i.e. temperature, flowrate and pressure) should be investigated.

3. Stability studies should be performed as well. 


\section{References}

1. Anderson, B. R. The Fischer-Tropsch Synthesis. Academic Press, Inc, Orlando FL 1984.

2. Röper, M., “Fischer-Tropsch synthesis”, in W. Keim, ed., Catalysis in C1 chemistry, D. Reidel, Dordrecht, The Netherlands, 1983 pp. 41-88.

3. Kolbel, H., and M. Ralek. "The Fischer-Tropsch Synthesis in Liquid phase." Catalysis Reviews. 21.2 (1980): 225-274.

4. Vannice, M. "The Catalytic Synthesis of Hydrocarbons from Co and H2 over Group VIII Metals: The Catalytic Behavior of Silica-Supported Metals." Journal of Catalysis. 50.2 (1977): 228-236.

5. Rao, V. U. S., G.J Stiegel, G.J. Cinquegrane, and R.D. Srivastava. "Iron-based catalysts for slurry-phase Fischer-Tropsch process: Technology review." Fuel Processing Technology. 30. (1992): 83-107.

6. Anderson, R.B., Catalysts for the Fischer-Tropsch synthesis, vol. 4, Van Nostrand Reinhold, New York 1956.

7. Dry, M.E. "Fischer-Tropsch Synthesis Over Iron Catalysts." Catalysis Letters. 7 (1990): 241-252.

8. Eilers, J, SA Posthuma, and ST Sie. "The Shell Middle Distillate Synthesis Process." Catalysis Letters. 7. (1990): 253-270.

9. Chaumette, P., Ph. Courty, A. Kiennemann, and B. Ernst. "Higher Alcohol and Paraffin Synthesis on Cobalt Based Catalysts: Comparison of Mechanistic Aspects." Topics in Catalysis. 2. (1995): 117-126.

10. Ma, W., E.L. Kugler, and D.B. Dadyburjor. "Effect of Mo Loading and Support Type on Hydrocarbons and Oxygenates Produced over Fe-Mo-Cu-K Catalysts Supported on Activated Carbons." (2005): 1-12.

11. O'Brian, R.J., and B.H. Davis. "Impact of copper on an alkali promoted iron FischerTropsch catalyst." Catalysis Letters. 94.1-2 (2004): 1-6.

12. Ma, W., E.L. Kugler, and D.B. Dadyburjor. "Potassium Effects on Activated-CarbonSupported Iron Catalysts for Fischer-Tropsch Synthesis." Energy \& Fuels. 21. (2007): 1832-1842.

13. Baltrus, J.P., J.R. Diehl, M.A. McDonald, and M.F. Zarochak. "Effects of Pretreatment on the Surface Properties of Iron Fischer-Tropsch Catalysts.” Applied Catalysis. 48 (1989): 199-213.

14. Luo, M., and D.h. Davis. "Fischer-Tropsch Synthesis: Activation of Low-Alpha Potassium Promoted Iron Catalysts.” Fuel Processing Technology. 83 (2003): 4965.

15. Arabczyk, W., U. Narkiewicz, and D. Moszynski. "Chlorine as a poison of the fused iron catalyst for ammonia synthesis." Applied Catalysis A: General. 134.2 (1996): 331-338.

16. Kishi, K. and M.W. Roberts. "Carbon Monoxide Adsorption on Iron in the Temperature Range 85 to $350 \mathrm{~K}$ as Revealed by X-Ray and Vacuum Ultraviolet [He(II)] Photoelectron Spectroscopy.” J. Chem. Soc. Faraday Trans. 71 (1975): 1715-1720. 
17. Tavakoli, A., M. Sohrabi, and A. Kargari. "Application of Anderson-Schulz-Flory (ASF) equation in the product distribution of slurry phase FT synthesis with nanosized iron catalysts." Chemical Engineering Journal. 136. (2008): 358-363.

18. Puskas, I., and R.S. Hurlbut. "Comments about the causes of deviations from the Anderson-Schulz-Flory distribution of the Fischer-Tropsch reaction products." Catalysis Today. 84.1-2 (2003): 99-109.

19. Koenig, L., and J. Gaube. "Fischer-Tropcsh Synthesis-Recent Studies and Developments." Chem.-Ing.-Tech. 55. (1983): 14-22.

20. Stenger, H. "Distributed chain growth probabilities for the Fischer-Tropsch synthesis ." Journal of Catalysis. 92.2 (1985): 426-428.

21. Ma, W., E.L. Kugler, and D.B. Dadyburjor. "Effect of Properties of Various Activated-Carbon Supports and Supported Fe-Mo-Cu-K Catalysts on Metal Precursor Distribution, Metal Reduction, and Fischer-Tropsch Synthesis.” Energy and Fuels. 24 (2010): 4099-4110.

22. Ma, W., E.L. Kugler, and D.B. Dadyburjor. "The Promotional Effect of Copper on Activity and Selectivity to Hydrocarbons and Oxygenates for Fischer-Tropsch Synthesis Over Potassium-Promoted Iron Catalysts Supported on Activated Carbon” Energy and Fuels. In Press.

23. Allen, D.M., and F.B. Cady, Analyzing Experimental Data by Regression, Wadsworth Publishing Company, 1982.

24. Ma, W., E.L. Kugler, J. Wright, and D.B. Dadyburjor. "Mo-Fe Catalysts Supported on Activated Carbon for Synthesis of Liquid Fuels by the Fisher-Tropsch Process: Effect of Mo Addition on Reducibility, Activity, and Hydrocarbon Selectivity" Energy and Fuels. 20 (2006): 2299-2307. 


\section{Appendix I}

\section{Data for Aqueous Phase}

for

Varied Mo Catalysts 
0\%Mo, $16 \% \mathrm{Fe}, 0.8 \% \mathrm{Cu}, 0.9 \% \mathrm{~K}$

\begin{tabular}{|l|r|r|}
\hline Total Volume $(\mathrm{mL})$ & 0.7 & Sample Volume $(\mathrm{mL})$ \\
\hline
\end{tabular}

\begin{tabular}{|c|c|c|c|c|c|}
\hline $\mathbf{X}_{\text {standard }}$ & $A_{x, \text { standard }}$ & $\mathbf{A}_{\text {cyclohexanol, standard }}$ & $\mathrm{Wt}_{\text {cyclohexanol, standard }}(\mu \mathrm{g})$ & $\mathbf{W t}_{\mathrm{x}, \text { standard }}(\mu \mathrm{g})$ & \\
\hline Methanol & 84286 & 19451 & 22.2 & 383.7 & \\
\hline Ethanol & 82843 & 16693 & 18.3 & 225.6 & \\
\hline 2-Propanol & 12534417 & 290032 & 5.8 & 816.1 & \\
\hline 1-Propanol & 78959 & 16539 & 19.5 & 305.1 & \\
\hline 2-Butanol & 31995228 & 1832669 & 34.2 & 796.5 & \\
\hline 1-Butanol & 82482 & 18344 & 18.1 & 391.4 & \\
\hline 2-Pentanol & 41499452 & 135882 & 21 & 783.9 & \\
\hline 1-Pentanol & 77869 & 19888 & 18.8 & 388.3 & \\
\hline $\mathbf{X}_{\text {sample }}$ & $A_{x, \text { sample }}$ & $\mathbf{A}_{\text {corrected, } \mathbf{x} \text {, sample }}$ & $\mathbf{A}_{\text {cyclohexanol, sample }}$ & $\mathrm{Wt}_{\text {cyclohexanol, sample }}(\mu \mathrm{g})$ & $\mathbf{W t}_{\mathrm{x}, \text { sample }}(\mu \mathrm{g})$ \\
\hline Methanol & 684039 & $\begin{array}{r}6837661.4 \\
\end{array}$ & 2822397 & 32200 & 31127.5 \\
\hline Ethanol & 4022392 & 41860601.6 & 2822397 & 32200 & 113995.8 \\
\hline 2-Propanol & 60120 & 34298463.6 & 2822397 & 32200 & 2233.1 \\
\hline 1-Propanol & 1194446 & 11557899.8 & 2822397 & 32200 & 44660.1 \\
\hline 2-Butanol & 0 & 0.0 & 2822397 & 32200 & 0.0 \\
\hline 1-Butanol & 588255 & 6801721.8 & 2822397 & 32200 & 32276.1 \\
\hline 2-Pentanol & 0 & 0.0 & 2822397 & 32200 & 0.0 \\
\hline \multirow[t]{2}{*}{ 1-Pentanol } & 247949 & 2992494.7 & 2822397 & 32200 & 14922.3 \\
\hline & MW & Weight (mg) & $\mathrm{mmol}_{\text {sample }}$ & & \\
\hline Methanol & 32.04 & 36.315 & 1.133 & & \\
\hline \begin{tabular}{|l|} 
Ethanol \\
\end{tabular} & 46.07 & 132.995 & 2.887 & & \\
\hline 2-Propanol & 60.10 & 2.605 & 0.043 & & \\
\hline 1-Propanol & 60.10 & 52.103 & 0.867 & \multirow{3}{*}{$\begin{array}{c}\text { Total Oxygenate } \\
\text { Weight (mg) (based on } \\
\text { sample volume) }\end{array}$} & \multirow{3}{*}{239.21} \\
\hline 2-Butanol & 74.13 & 0.000 & 0.000 & & \\
\hline 1-Butanol & 74.13 & 37.655 & 0.508 & & \\
\hline 2-Pentanol & 88.16 & 0.000 & 0.000 & \multirow{3}{*}{$\begin{array}{c}\text { Total Oxygenate } \\
\text { Weight (mg) (based on } \\
\text { total volume) }\end{array}$} & \multirow{3}{*}{279.08} \\
\hline 1-Pentanol & 88.16 & 17.409 & 0.197 & & \\
\hline Water & 18.01 & 395.416 & 21.955 & & \\
\hline & & & & $\begin{array}{c}\text { Weight Percent of } \\
\text { Water }\end{array}$ & 58.62 \\
\hline
\end{tabular}


$3 \% \mathrm{Mo}, 16 \% \mathrm{Fe}, 0.8 \% \mathrm{Cu}, 0.9 \% \mathrm{~K}$ \begin{tabular}{|l|l|l|}
\hline Total Volume $(\mathrm{mL})$ & 1.1 & Sample Volume $(\mathrm{mL})$ \\
\hline
\end{tabular}

\begin{tabular}{|c|c|c|c|c|c|}
\hline $\mathbf{X}_{\text {standard }}$ & $A_{x, \text { standard }}$ & $\mathbf{A}_{\text {cyclohexanol, standard }}$ & $\mathrm{Wt}_{\text {cyclohexanol, standard }}(\mu \mathrm{g})$ & $\mathrm{Wt}_{\mathrm{x}, \text { standard }}(\mu \mathrm{g})$ & \\
\hline Methanol & 84286 & 19451 & 22.2 & 383.7 & \\
\hline Ethanol & 82843 & 16693 & 18.3 & 225.6 & \\
\hline 2-Propanol & 12534417 & 290032 & 5.8 & 816.1 & \\
\hline 1-Propanol & 78959 & 16539 & 19.5 & 305.1 & \\
\hline 2-Butanol & 31995228 & 1832669 & 34.2 & 796.5 & \\
\hline 1-Butanol & 82482 & 18344 & 18.1 & 391.4 & \\
\hline 2-Pentanol & 41499452 & 135882 & 21 & 783.9 & \\
\hline 1-Pentanol & 77869 & 19888 & 18.8 & 388.3 & \\
\hline $\mathbf{X}_{\text {sample }}$ & $\mathbf{A}_{\mathbf{x}, \text { sample }}$ & $A_{\text {corrected, } x, \text { sample }}$ & $\mathbf{A}_{\text {cyclohexanol, sample }}$ & $\mathrm{Wt}_{\text {cyclohexanol, sample }}(\mu \mathrm{g})$ & $\mathbf{W t}_{\mathrm{x}, \text { sample }}(\mu \mathrm{g})$ \\
\hline Methanol & 1695497 & 17745284.5 & 2486334 & 29700 & 80782.9 \\
\hline Ethanol & 6730233 & 73334845.9 & 2486334 & 29700 & 199707.2 \\
\hline 2-Propanol & 850400 & 507970107.1 & 2486334 & 29700 & 33073.3 \\
\hline 1-Propanol & 1780927 & 18043373.3 & 2486334 & 29700 & 69720.1 \\
\hline 2-Butanol & 653890 & 418561813.3 & 2486334 & 29700 & 10419.8 \\
\hline 1-Butanol & 1872088 & 22664112.0 & 2486334 & 29700 & 107547.5 \\
\hline 2-Pentanol & 334900 & 25885393.0 & 2486334 & 29700 & 489.0 \\
\hline 1-Pentanol & 1114289 & 14080824.5 & 2486334 & 29700 & 70215.2 \\
\hline & MW & Weight (mg) & $\mathrm{mmol}_{\text {sample }}$ & & \\
\hline Methanol & 32.04 & 88.861 & 2.773 & & \\
\hline Ethanol & 46.07 & 219.678 & 4.768 & & \\
\hline 2-Propanol & 60.10 & 36.381 & 0.605 & & \\
\hline 1-Propanol & 60.10 & 76.692 & 1.276 & \multirow{3}{*}{$\begin{array}{c}\text { Total Oxygenate } \\
\text { Weight (mg) (based on } \\
\text { sample volume) }\end{array}$} & \multirow{3}{*}{571.95} \\
\hline 2-Butanol & 74.13 & 11.462 & 0.155 & & \\
\hline 1-Butanol & 74.13 & 118.302 & 1.596 & & \\
\hline 2-Pentanol & 88.16 & 0.538 & 0.006 & \multirow{3}{*}{$\begin{array}{c}\text { Total Oxygenate } \\
\text { Weight (mg) (based on } \\
\text { total volume) }\end{array}$} & \multirow{3}{*}{629.15} \\
\hline 1-Pentanol & 88.16 & 77.237 & 0.876 & & \\
\hline Water & 18.01 & 462.850 & 25.700 & & \\
\hline
\end{tabular}


$6 \% \mathrm{Mo}, 16 \% \mathrm{Fe}, 0.8 \% \mathrm{Cu}, 0.9 \% \mathrm{~K}$ \begin{tabular}{|l|l|l|}
\hline Total Volume $(\mathrm{mL})$ & 2.2 & Sample Volume $(\mathrm{mL})$ \\
\hline
\end{tabular}

\begin{tabular}{|c|c|c|c|c|c|}
\hline $\mathbf{X}_{\text {standard }}$ & $\mathbf{A}_{\mathbf{x}, \text { standard }}$ & $\mathbf{A}_{\text {cyclohexanol, standard }}$ & $\mathbf{W t}_{\text {cyclohexanol, standard }}(\mu \mathrm{g})$ & $\mathbf{W t}_{\mathrm{x}, \text { standard }}(\mu \mathrm{g})$ & \\
\hline Methanol & 84286 & 19451 & 22.2 & 383.7 & \\
\hline Ethanol & 82843 & 16693 & 18.3 & 225.6 & \\
\hline 2-Propanol & 12534417 & 290032 & 5.8 & 816.1 & \\
\hline 1-Propanol & 78959 & 16539 & 19.5 & 305.1 & \\
\hline 2-Butanol & 31995228 & 1832669 & 34.2 & 796.5 & \\
\hline 1-Butanol & 82482 & 18344 & 18.1 & 391.4 & \\
\hline 2-Pentanol & 41499452 & 135882 & 21 & 783.9 & \\
\hline 1-Pentanol & 77869 & 19888 & 18.8 & 388.3 & \\
\hline $\mathbf{X}_{\text {sample }}$ & $A_{x, \text { sample }}$ & $A_{\text {corrected }, x, \text { sample }}$ & $A_{\text {cyclohexanol, sample }}$ & $\mathbf{W t}_{\text {cyclohexanol, sample }}(\mu \mathrm{g})$ & $\mathrm{Wt}_{\mathrm{x}, \text { sample }}(\mu \mathrm{g})$ \\
\hline Methanol & 2866151 & 20982610.3 & 4260676 & 35600 & 95520.3 \\
\hline Ethanol & 9081517 & 69217066.9 & 4260676 & 35600 & 188493.5 \\
\hline 2-Propanol & 1111808 & 464535818.8 & 4260676 & 35600 & 30245.3 \\
\hline 1-Propanol & 3493646 & 24758539.4 & 4260676 & 35600 & 95667.8 \\
\hline 2-Butanol & 1002701 & 448952985.4 & 4260676 & 35600 & 11176.4 \\
\hline 1-Butanol & 1769821 & 14987054.9 & 4260676 & 35600 & 71117.7 \\
\hline 2-Pentanol & 392102 & 21198892.9 & 4260676 & 35600 & 400.4 \\
\hline \multirow[t]{2}{*}{ 1-Pentanol } & 869456 & 7685150.2 & 4260676 & 35600 & 38322.6 \\
\hline & MW & Weight (mg) & $\mathrm{mmol}_{\text {sample }}$ & & \\
\hline Methanol & 32.04 & 262.681 & 8.199 & & \\
\hline Ethanol & 46.07 & 518.357 & 11.252 & & \\
\hline 2-Propanol & 60.10 & 83.175 & 1.384 & & \\
\hline 1-Propanol & 60.10 & 263.086 & 4.377 & & \\
\hline 2-Butanol & 74.13 & 30.735 & 0.415 & \multirow{3}{*}{$\begin{array}{c}\text { Total Oxygenate } \\
\text { Weight (mg) (based on } \\
\text { sample volume) }\end{array}$} & \multirow{3}{*}{530.94} \\
\hline 1-Butanol & 74.13 & 195.574 & 2.638 & & \\
\hline 2-Pentanol & 88.16 & 1.101 & 0.012 & & \\
\hline 1-Pentanol & 88.16 & 105.387 & 1.195 & \multirow{3}{*}{$\begin{array}{c}\text { Total Oxygenate } \\
\text { Weight (mg) (based on } \\
\text { total volume) }\end{array}$} & \multirow{3}{*}{1460.10} \\
\hline Water & 18.01 & 549.904 & 30.533 & & \\
\hline \multirow{2}{*}{\multicolumn{4}{|c|}{ (2) }} & & \\
\hline & & & & $\begin{array}{c}\text { Weight Percent of } \\
\text { Water }\end{array}$ & 27.36 \\
\hline
\end{tabular}


$12 \% \mathrm{Mo}, 16 \% \mathrm{Fe}, 0.8 \% \mathrm{Cu}, 0.9 \% \mathrm{~K}$ \begin{tabular}{|l|l|l|}
\hline Total Volume $(\mathrm{mL})$ & 1 & Sample Volume $(\mathrm{mL})$ \\
\hline
\end{tabular}

\begin{tabular}{|c|c|c|c|c|c|}
\hline $\mathbf{X}_{\text {standard }}$ & $\mathbf{A}_{\mathrm{x}, \text { standard }}$ & $\mathrm{A}_{\text {cyclohexanol, standard }}$ & $\mathrm{Wt}_{\text {cyclohexanol, standard }}(\boldsymbol{\mu g})$ & $\mathbf{W t}_{\mathrm{x}, \text { standard }}(\mu \mathrm{g})$ & \\
\hline Methanol & 84286 & 19451 & 22.2 & 383.7 & \\
\hline Ethanol & 82843 & 16693 & 18.3 & 225.6 & \\
\hline 2-Propanol & 12534417 & 290032 & 5.8 & 816.1 & \\
\hline 1-Propanol & 78959 & 16539 & 19.5 & 305.1 & \\
\hline 2-Butanol & 31995228 & 1832669 & 34.2 & 796.5 & \\
\hline 1-Butanol & 82482 & 18344 & 18.1 & 391.4 & \\
\hline 2-Pentanol & 41499452 & 135882 & 21 & 783.9 & \\
\hline 1-Pentanol & 77869 & 19888 & 18.8 & 388.3 & \\
\hline $\mathbf{X}_{\text {sample }}$ & $A_{x, \text { sample }}$ & $A_{\text {corrected, } \mathbf{x}, \text { sample }}$ & $A_{\text {cyclohexanol, sample }}$ & $\mathbf{W t}_{\text {cyclohexanol, sample }}(\mu \mathrm{g})$ & $W_{t} t_{\text {sample }}(\mu g)$ \\
\hline Methanol & 3009121 & 29917491.7 & 2220772 & 25200 & 136195.1 \\
\hline Ethanol & 5954056 & 61630087.8 & 2220772 & 25200 & 167832.5 \\
\hline 2-Propanol & 607818 & 344895913.5 & 2220772 & 25200 & 22455.7 \\
\hline 1-Propanol & 1614686 & 15540295.9 & 2220772 & 25200 & 60048.2 \\
\hline 2-Butanol & 444402 & 270228095.3 & 2220772 & 25200 & 6727.1 \\
\hline 1-Butanol & 1015399 & 11677470.2 & 2220772 & 25200 & 55412.8 \\
\hline 2-Pentanol & 132728 & 9745446.8 & 2220772 & 25200 & 184.1 \\
\hline \multirow[t]{2}{*}{ 1-Pentanol } & 525481 & 6307929.7 & 2220772 & 25200 & 31455.0 \\
\hline & MW & Weight (mg) & $\mathrm{mmol}_{\text {sample }}$ & & \\
\hline Methanol & 32.04 & 151.328 & 4.723 & & \\
\hline Ethanol & 46.07 & 186.481 & 4.048 & & \\
\hline 2-Propanol & 60.10 & 24.951 & 0.415 & \multirow{3}{*}{$\begin{array}{c}\text { Total Oxygenate } \\
\text { Weight (mg) (based on } \\
\text { sample volume) }\end{array}$} & \multirow{3}{*}{480.31} \\
\hline 1-Propanol & 60.10 & 66.720 & 1.110 & & \\
\hline 2-Butanol & 74.13 & 7.475 & 0.101 & & \\
\hline 1-Butanol & 74.13 & 61.570 & 0.831 & \multirow{3}{*}{$\begin{array}{c}\text { Total Oxygenate } \\
\text { Weight (mg) (based on } \\
\text { total volume) }\end{array}$} & \multirow{3}{*}{533.68} \\
\hline 2-Pentanol & 88.16 & 0.205 & 0.002 & & \\
\hline 1-Pentanol & 88.16 & 34.950 & 0.396 & & \\
\hline Water & 18.01 & 390.222 & 21.667 & $\begin{array}{c}\text { Weight Percent of } \\
\text { Water }\end{array}$ & 42.24 \\
\hline
\end{tabular}


Appendix II

\author{
Data for Oil Phase \\ for \\ Varied Mo Catalysts
}


0\%Mo, $16 \% \mathrm{Fe}, 0.8 \% \mathrm{Cu}, 0.9 \% \mathrm{~K}$ Injection Volume $(\mu \mathrm{L})$

\section{\begin{tabular}{|l|l|}
\hline Correction factor & 0.845706583 \\
\hline
\end{tabular}}

\begin{tabular}{|c|c|c|c|c|c|c|c|c|}
\hline Compound & MW & \begin{tabular}{|c|}
$\begin{array}{c}\text { Weight Percent } \\
\text { from GC }\end{array}$ \\
\end{tabular} & Area & $\begin{array}{c}\text { Weight in } \\
\text { injection }(\mu \mathrm{g})\end{array}$ & $\begin{array}{c}\text { Weight in } \\
\text { Sample (mg) }\end{array}$ & $\begin{array}{c}\text { Corrected Weight } \\
\text { in Sample (mg) }\end{array}$ & $\begin{array}{c}\text { Amount in } \\
\text { Moles (mmols) }\end{array}$ & $\begin{array}{l}\text { Weight } \\
\text { Percent }\end{array}$ \\
\hline $\mathrm{C}_{6 \text { (parafin) }}$ & 86.20 & 3.6859 & 74517 & 4.284 & 184.232 & 155.806 & 1.807 & 4.283 \\
\hline $\mathrm{C}_{7 \text { (parafin) }}$ & 100.23 & 11.5904 & 234635 & 14.531 & 624.848 & 528.438 & 5.272 & 14.528 \\
\hline $\mathrm{C}_{7 \text { (olefin) }}$ & 98.21 & 5.2102 & 105475 & 6.266 & 269.423 & 227.853 & 2.320 & 6.264 \\
\hline$C_{8 \text { (parafin) }}$ & 114.26 & 11.6439 & 235717 & 14.601 & 627.826 & 530.956 & 4.647 & 14.597 \\
\hline $\mathrm{C}_{8 \text { (olefin) }}$ & 112.24 & 6.8804 & 139286 & 8.429 & 362.465 & 306.539 & 2.731 & 8.427 \\
\hline $\mathrm{C}_{9 \text { (i-parafin) }}$ & 128.29 & 2.9368 & 59452 & 3.320 & 142.776 & 120.746 & 0.941 & 3.320 \\
\hline $\mathrm{C}_{9 \text { (parafin) }}$ & 128.29 & 5.8881 & 119198 & 7.144 & 307.186 & 259.789 & 2.025 & 7.142 \\
\hline $\mathrm{C}_{9 \text { (olefin) }}$ & 126.27 & 6.3436 & 128418 & 7.734 & 332.558 & 281.246 & 2.227 & 7.732 \\
\hline $\mathrm{C}_{10 \text { (parafin) }}$ & 142.32 & 5.9412 & 120272 & 7.213 & 310.142 & 262.289 & 1.843 & 7.211 \\
\hline $\mathrm{C}_{10 \text { (olefin) }}$ & 140.30 & 4.8113 & 97398 & 5.749 & 247.196 & 209.056 & 1.490 & 5.747 \\
\hline $\mathrm{C}_{11 \text { (parafin) }}$ & 156.35 & 3.7274 & 75458 & 4.345 & 186.821 & 157.996 & 1.011 & 4.344 \\
\hline$C_{11 \text { (olefin) }}$ & 154.33 & 3.046 & 61663 & 3.462 & 148.860 & 125.892 & 0.816 & 3.461 \\
\hline $\mathrm{C}_{12 \text { (parafin) }}$ & 170.38 & 3.003 & 60792 & 3.406 & 146.463 & 123.865 & 0.727 & 3.405 \\
\hline $\mathrm{C}_{12 \text { (olefin) }}$ & 168.36 & 2.1099 & 42713 & 2.249 & 96.713 & 81.791 & 0.486 & 2.249 \\
\hline $\mathrm{C}_{13 \text { (parafin) }}$ & 184.41 & 2.0602 & 41706 & 2.185 & 93.942 & 79.447 & 0.431 & 2.184 \\
\hline $\mathrm{C}_{13 \text { (olefin) }}$ & 182.39 & 1.5695 & 31773 & 1.549 & 66.608 & 56.331 & 0.309 & 1.549 \\
\hline $\mathrm{C}_{14 \text { (parafin) }}$ & 198.44 & 1.3516 & 27361 & 1.267 & 54.467 & 46.063 & 0.232 & 1.266 \\
\hline$C_{14 \text { (olefin) }}$ & 196.42 & 1.2472 & 25249 & 1.132 & 48.655 & 41.148 & 0.209 & 1.131 \\
\hline $\mathrm{C}_{15 \text { (parafin) }}$ & 212.47 & 0.871 & 17632 & 0.644 & 27.694 & 23.421 & 0.110 & 0.644 \\
\hline $\mathrm{C}_{16}{ }^{+}$ & 226.50 & 0.53 & 15616 & 0.515 & 22.147 & 18.730 & 0.083 & 0.515 \\
\hline
\end{tabular}

Total

100.024

4301.021

3637.402

\begin{tabular}{|l|l|}
\hline 29.718 & 100.000 \\
\hline
\end{tabular} 
$3 \% \mathrm{Mo}, 16 \% \mathrm{Fe}, 0.8 \% \mathrm{Cu}, 0.9 \% \mathrm{~K}$

\begin{tabular}{|c|c|c|c|c|}
\hline Injection Volume $(\mu \mathrm{L})$ & 0.1 & Total Volume $(\mu \mathrm{L})$ & \begin{tabular}{l|l|}
900 & Total Weight $(\mathbf{m g})$
\end{tabular} & 737.4 \\
\hline
\end{tabular}

\section{\begin{tabular}{|l|r|} 
Correction factor & 1.06564517 \\
\hline
\end{tabular}}

\begin{tabular}{|c|c|c|c|c|c|c|c|c|}
\hline Compound & MW & \begin{tabular}{|c|}
$\begin{array}{c}\text { Weight Percent } \\
\text { from GC }\end{array}$ \\
\end{tabular} & Area & $\begin{array}{c}\text { Weight in } \\
\text { injection }(\mu \mathrm{g})\end{array}$ & $\begin{array}{c}\text { Weight in } \\
\text { Sample (mg) }\end{array}$ & $\begin{array}{c}\begin{array}{c}\text { Corrected Weight } \\
\text { in Sample (mg) }\end{array} \\
\end{array}$ & \begin{tabular}{|c|} 
Amount in \\
Moles (mmols) \\
\end{tabular} & $\begin{array}{l}\text { Weight } \\
\text { Percent }\end{array}$ \\
\hline $\mathrm{C}_{6 \text { (parafin) }}$ & 86.20 & 1.2478 & 20894 & 0.853 & 7.675 & 8.179 & 0.0949 & 1.106 \\
\hline $\mathrm{C}_{7 \text { (parafin) }}$ & 100.23 & 9.5072 & 159193 & 9.703 & 87.330 & 93.063 & 0.9285 & 12.581 \\
\hline $\mathrm{C}_{7 \text { (olefin) }}$ & 98.21 & 1.3257 & 22198 & 0.936 & 8.426 & 8.979 & 0.0914 & 1.214 \\
\hline $\mathrm{C}_{8 \text { (i-parafin) }}$ & 114.26 & 1.3375 & 22396 & 0.949 & 8.540 & 9.101 & 0.0797 & 1.230 \\
\hline $\mathrm{C}_{8 \text { (parafin) }}$ & 114.26 & 13.4508 & 225227 & 13.929 & 125.364 & 133.593 & 1.1692 & 18.060 \\
\hline $\mathrm{C}_{8 \text { (olefin) }}$ & 112.24 & 3.7764 & 63234 & 3.562 & 32.062 & 34.166 & 0.3044 & 4.619 \\
\hline $\mathrm{C}_{9 \text { (i-parafin) }}$ & 128.29 & 1.9614 & 32843 & 1.617 & 14.557 & 15.513 & 0.1209 & 2.097 \\
\hline $\mathrm{C}_{9 \text { (parafin) }}$ & 128.29 & 12.7134 & 212880 & 13.139 & 118.252 & 126.015 & 0.9823 & 17.036 \\
\hline $\mathrm{C}_{9 \text { (olefin) }}$ & 126.27 & 2.5448 & 42612 & 2.243 & 20.184 & 21.509 & 0.1703 & 2.908 \\
\hline $\mathrm{C}_{10 \text { (parafin) }}$ & 142.32 & 9.3215 & 156084 & 9.504 & 85.540 & 91.155 & 0.6405 & 12.323 \\
\hline $\mathrm{C}_{10 \text { (olefin) }}$ & 140.30 & 3.4384 & 57575 & 3.200 & 28.802 & 30.693 & 0.2188 & 4.149 \\
\hline $\mathrm{C}_{11 \text { (parafin) }}$ & 156.35 & 5.9665 & 99907 & 5.909 & 53.184 & 56.675 & 0.3625 & 7.662 \\
\hline $\mathrm{C}_{11 \text { (olefin) }}$ & 154.33 & 2.0167 & 33769 & 1.677 & 15.091 & 16.081 & 0.1042 & 2.174 \\
\hline $\mathrm{C}_{12 \text { (parafin) }}$ & 170.38 & 4.1101 & 68822 & 3.920 & 35.280 & 37.596 & 0.2207 & 5.082 \\
\hline $\mathrm{C}_{12 \text { (olefin) }}$ & 168.36 & 1.2152 & 20348 & 0.818 & 7.361 & 7.844 & 0.0466 & 1.060 \\
\hline $\mathrm{C}_{13 \text { (parafin) }}$ & 184.41 & 2.6822 & 44912 & 2.390 & 21.509 & 22.921 & 0.1243 & 3.099 \\
\hline $\mathrm{C}_{13 \text { (olefin) }}$ & 182.39 & 0.5761 & 9646 & 0.133 & 1.197 & 1.275 & 0.0070 & 0.172 \\
\hline $\mathrm{C}_{14 \text { (parafin) }}$ & 198.44 & 1.6031 & 26842 & 1.233 & 11.101 & 11.830 & 0.0596 & 1.599 \\
\hline $\mathrm{C}_{15^{+}}$ & 212.47 & 1.768 & 29606 & 1.410 & 12.693 & 13.526 & 0.0637 & 1.829 \\
\hline
\end{tabular}

\begin{tabular}{l|l|l|l|l|l|} 
Total & 77.128 & 694.148 & 739.716 & 5.789 & 100.000 \\
\hline
\end{tabular}


$6 \% \mathrm{Mo}, 16 \% \mathrm{Fe}, 0.8 \% \mathrm{Cu}, 0.9 \% \mathrm{~K}$

\begin{tabular}{|l|l|l|}
\hline Injection Volume $(\mu \mathrm{L})$ & 0.1 & Total Volume $(\mu \mathrm{L})$ \\
\hline
\end{tabular}

Correction factor 0.647836391

\begin{tabular}{|c|c|c|c|c|c|c|c|c|}
\hline Compound & MW & $\begin{array}{c}\text { Weight Percent } \\
\text { from GC }\end{array}$ & Area & $\begin{array}{c}\text { Weight in } \\
\text { injection }(\mu \mathrm{g})\end{array}$ & $\begin{array}{c}\text { Weight in } \\
\text { Sample (mg) }\end{array}$ & \begin{tabular}{|c|}
$\begin{array}{c}\text { Corrected Weight } \\
\text { in Sample (mg) }\end{array}$ \\
\end{tabular} & \begin{tabular}{|c|} 
Amount in \\
Moles (mmols)
\end{tabular} & $\begin{array}{l}\text { Weight } \\
\text { Percent } \\
\end{array}$ \\
\hline $\mathrm{C}_{6 \text { (parafin) }}$ & 86.20 & 5.5722 & 109924 & 6.550 & 65.504 & 42.436 & 0.492 & 6.414 \\
\hline $\mathrm{C}_{7 \text { (parafin) }}$ & 100.23 & 13.8787 & 273786 & 17.037 & 170.369 & 110.371 & 1.101 & 16.683 \\
\hline $\mathrm{C}_{7 \text { (olefin) }}$ & 98.21 & 3.033 & 59832 & 3.345 & 33.447 & 21.668 & 0.221 & 3.275 \\
\hline $\mathrm{C}_{8 \text { (i-parafin) }}$ & 114.26 & 1.6592 & 32731 & 1.610 & 16.103 & 10.432 & 0.091 & 1.577 \\
\hline $\mathrm{C}_{8 \text { (parafin) }}$ & 114.26 & 15.3226 & 302271 & 18.860 & 188.598 & 122.181 & 1.069 & 18.468 \\
\hline $\mathrm{C}_{8 \text { (olefin) }}$ & 112.24 & 2.2888 & 45152 & 2.405 & 24.052 & 15.582 & 0.139 & 2.355 \\
\hline $\mathrm{C}_{9 \text { (i-parafin) }}$ & 128.29 & 1.944 & 38349 & 1.970 & 19.699 & 12.761 & 0.099 & 1.929 \\
\hline $\mathrm{C}_{9 \text { (parafin) }}$ & 128.29 & 12.0555 & 237820 & 14.735 & 147.352 & 95.460 & 0.744 & 14.429 \\
\hline $\mathrm{C}_{9 \text { (olefin) }}$ & 126.27 & 1.4649 & 28899 & 1.365 & 13.651 & 8.844 & 0.070 & 1.337 \\
\hline $\mathrm{C}_{10 \text { (parafin) }}$ & 142.32 & 8.0837 & 159469 & 9.721 & 97.210 & 62.976 & 0.442 & 9.519 \\
\hline $\mathrm{C}_{10 \text { (olefin) }}$ & 140.30 & 2.5608 & 50516 & 2.748 & 27.485 & 17.806 & 0.127 & 2.691 \\
\hline $\mathrm{C}_{11 \text { (parafin) }}$ & 156.35 & 5.0808 & 100229 & 5.930 & 59.299 & 38.416 & 0.246 & 5.807 \\
\hline $\mathrm{C}_{11 \text { (olefin) }}$ & 154.33 & 1.5156 & 29899 & 1.429 & 14.291 & 9.258 & 0.060 & 1.399 \\
\hline $\mathrm{C}_{12 \text { (parafin) }}$ & 170.38 & 3.2896 & 64894 & 3.669 & 36.686 & 23.767 & 0.139 & 3.592 \\
\hline $\mathrm{C}_{12 \text { (olefin) }}$ & 168.36 & 0.8171 & 16120 & 0.547 & 5.473 & 3.546 & 0.021 & 0.536 \\
\hline $\mathrm{C}_{13 \text { (parafin) }}$ & 184.41 & 2.3217 & 45800 & 2.447 & 24.467 & 15.851 & 0.086 & 2.396 \\
\hline $\mathrm{C}_{13 \text { (olefin) }}$ & 182.39 & 0.4737 & 9344 & 0.114 & 1.137 & 0.736 & 0.004 & 0.111 \\
\hline $\mathrm{C}_{14}+$ & 198.44 & 6.3565 & 126940 & 7.639 & 76.393 & 49.490 & 0.249 & 7.481 \\
\hline
\end{tabular}


Appendix III

Data for Aqueous Phase

for

Varied Fe Catalysts 
$6 \% \mathrm{Mo}, 8 \% \mathrm{Fe}, 0.8 \% \mathrm{Cu}, 0.9 \% \mathrm{~K}$ \begin{tabular}{|l|l|l|}
\hline Total Volume (mL) & 1.8 & Sample Volume $(\mathrm{mL})$ \\
\hline
\end{tabular}

\begin{tabular}{|c|c|c|c|c|c|}
\hline $\mathbf{X}_{\text {standard }}$ & $A_{x, \text { standard }}$ & $\mathrm{A}_{\text {cyclohexanol, standard }}$ & $\mathrm{Wt}_{\text {cyclohexanol, standard }}(\mu \mathrm{g})$ & $\mathbf{W t}_{\mathrm{x}, \text { standard }}(\boldsymbol{\mu g})$ & \\
\hline Methanol & 84286 & 19451 & 22.2 & 383.7 & \\
\hline Ethanol & 82843 & 16693 & 18.3 & 225.6 & \\
\hline 2-Propanol & 12534417 & 290032 & 5.8 & 816.1 & \\
\hline 1-Propanol & 78959 & 16539 & 19.5 & 305.1 & \\
\hline 2-Butanol & 31995228 & 1832669 & 34.2 & 796.5 & \\
\hline 1-Butanol & 82482 & 18344 & 18.1 & 391.4 & \\
\hline 2-Pentanol & 41499452 & 135882 & 21 & 783.9 & \\
\hline 1-Pentanol & 77869 & 19888 & 18.8 & 388.3 & \\
\hline $\mathbf{X}_{\text {sample }}$ & $A_{x, \text { sample }}$ & $\mathbf{A}_{\text {corrected, } \mathbf{x} \text {, sample }}$ & $\mathbf{A}_{\text {cyclohexanol, sample }}$ & $\mathrm{Wt}_{\text {cyclohexanol, sample }}(\mu \mathrm{g})$ & $\mathbf{W t}_{\mathrm{x}, \text { sample }}(\mu \mathrm{g})$ \\
\hline Methanol & 1074417 & 17087963.1 & 1052216 & 19100 & 77790.5 \\
\hline Ethanol & 3374332 & 55872689.9 & 1052216 & 19100 & 152153.8 \\
\hline 2-Propanol & 333098 & 302355877.2 & 1052216 & 19100 & 19686.0 \\
\hline 1-Propanol & 1411139 & 21725655.9 & 1052216 & 19100 & 83948.6 \\
\hline 2-Butanol & 266476 & 259205668.1 & 1052216 & 19100 & 6452.8 \\
\hline 1-Butanol & 499412 & 9187617.5 & 1052216 & 19100 & 43597.8 \\
\hline 2-Pentanol & 72455 & 8510194.0 & 1052216 & 19100 & 160.8 \\
\hline 1-Pentanol & 221958 & 4262187.3 & 1052216 & 19100 & 21253.7 \\
\hline & MW & Weight (mg) & $\mathrm{mmol}_{\text {sample }}$ & & \\
\hline Methanol & 32.04 & 233.372 & 7.284 & & \\
\hline Ethanol & 46.07 & 456.461 & 9.908 & & \\
\hline 2-Propanol & 60.10 & 59.058 & 0.983 & & \\
\hline 1-Propanol & 60.10 & 251.846 & 4.190 & \multirow{3}{*}{$\begin{array}{c}\text { Total Oxygenate } \\
\text { Weight (mg) (based on } \\
\text { sample volume) }\end{array}$} & \multirow{3}{*}{405.04} \\
\hline 2-Butanol & 74.13 & 19.358 & 0.261 & & \\
\hline 1-Butanol & 74.13 & 130.793 & 1.764 & & \\
\hline 2-Pentanol & 88.16 & 0.482 & 0.005 & \multirow{3}{*}{$\begin{array}{c}\text { Total Oxygenate } \\
\text { Weight (mg) (based on } \\
\text { total volume) }\end{array}$} & \multirow{3}{*}{1215.13} \\
\hline 1-Pentanol & 88.16 & 63.761 & 0.723 & & \\
\hline Water & 18.01 & 474.868 & 26.367 & & \\
\hline & & & & $\begin{array}{c}\text { Weight Percent of } \\
\text { Water }\end{array}$ & 28.10 \\
\hline
\end{tabular}


$6 \% \mathrm{Mo}, 32 \% \mathrm{Fe}, 0.8 \% \mathrm{Cu}, 0.9 \% \mathrm{~K}$ \begin{tabular}{|l|r|r|}
\hline Total Volume $(\mathrm{mL})$ & 2.45 & Sample Volume $(\mathrm{mL})$ \\
\hline
\end{tabular}

\begin{tabular}{|c|c|c|c|c|c|}
\hline $\mathbf{X}_{\text {standard }}$ & $A_{x, \text { standard }}$ & $\mathrm{A}_{\text {cyclohexanol, standard }}$ & $\mathrm{Wt}_{\text {cyclohexanol, standard }}(\mu \mathrm{g})$ & $\mathbf{W t}_{\mathrm{x}, \text { standard }}(\boldsymbol{\mu g})$ & \\
\hline Methanol & 84286 & 19451 & 22.2 & 383.7 & \\
\hline Ethanol & 82843 & 16693 & 18.3 & 225.6 & \\
\hline 2-Propanol & 12534417 & 290032 & 5.8 & 816.1 & \\
\hline 1-Propanol & 78959 & 16539 & 19.5 & 305.1 & \\
\hline 2-Butanol & 31995228 & 1832669 & 34.2 & 796.5 & \\
\hline 1-Butanol & 82482 & 18344 & 18.1 & 391.4 & \\
\hline 2-Pentanol & 41499452 & 135882 & 21 & 783.9 & \\
\hline 1-Pentanol & 77869 & 19888 & 18.8 & 388.3 & \\
\hline $\mathbf{X}_{\text {sample }}$ & $A_{x, \text { sample }}$ & A $_{\text {corrected, } x \text {, sample }}$ & $\mathbf{A}_{\text {cyclohexanol, sample }}$ & $\mathrm{Wt}_{\text {cyclohexanol, sample }}(\mu \mathrm{g})$ & $\mathbf{W t}_{\mathrm{x}, \text { sample }}(\mu \mathrm{g})$ \\
\hline Methanol & 1810043 & 21808990.2 & 2588763 & 35600 & 99282.3 \\
\hline Ethanol & 6081735 & 76290155.7 & 2588763 & 35600 & 207755.1 \\
\hline 2-Propanol & 836403 & 575163358.4 & 2588763 & 35600 & 37448.2 \\
\hline 1-Propanol & 219443 & 2559493.7 & 2588763 & 35600 & 9890.0 \\
\hline 2-Butanol & 657169 & 484275726.7 & 2588763 & 35600 & 12055.7 \\
\hline 1-Butanol & 1047284 & 14596127.2 & 2588763 & 35600 & 69262.7 \\
\hline 2-Pentanol & 249181 & 22172530.7 & 2588763 & 35600 & 418.8 \\
\hline \multirow[t]{2}{*}{ 1-Pentanol } & 779228 & 11335887.2 & 2588763 & 35600 & 56527.3 \\
\hline & MW & Weight (mg) & $\mathrm{mmol}_{\text {sample }}$ & & \\
\hline Methanol & 32.04 & 243.242 & 7.592 & & \\
\hline \begin{tabular}{|l|} 
Ethanol \\
\end{tabular} & 46.07 & 509.000 & 11.048 & & \\
\hline 2-Propanol & 60.10 & 91.748 & 1.527 & & \\
\hline 1-Propanol & 60.10 & 24.230 & 0.403 & \multirow{3}{*}{$\begin{array}{c}\text { Total Oxygenate } \\
\text { Weight (mg) (based on } \\
\text { sample volume) }\end{array}$} & \multirow{3}{*}{492.64} \\
\hline 2-Butanol & 74.13 & 29.537 & 0.398 & & \\
\hline 1-Butanol & 74.13 & 169.694 & 2.289 & & \\
\hline 2-Pentanol & 88.16 & 1.026 & 0.012 & \multirow{3}{*}{$\begin{array}{c}\text { Total Oxygenate } \\
\text { Weight (mg) (based on } \\
\text { total volume) }\end{array}$} & \multirow{3}{*}{1206.97} \\
\hline 1-Pentanol & 88.16 & 138.492 & 1.571 & & \\
\hline Water & 18.01 & 1023.032 & 56.804 & & \\
\hline & & & & $\begin{array}{c}\text { Weight Percent of } \\
\text { Water }\end{array}$ & 45.88 \\
\hline
\end{tabular}


Appendix IV

\author{
Data for Oil Phase \\ for \\ Varied Fe Catalysts
}


$6 \% \mathrm{Mo}, 8 \% \mathrm{Fe}, 0.8 \% \mathrm{Cu}, 0.9 \% \mathrm{~K}$

Injection Volume $(\mu \mathrm{L})$

$0.1 \quad$ Total Volume $(\mu \mathrm{L})$

$800 \quad$ Total Weight (mg)

\section{\begin{tabular}{|l|l|}
\hline Correction factor & 0.545618441 \\
\hline
\end{tabular}}

\begin{tabular}{|c|c|c|c|c|c|c|c|c|}
\hline Compound & MW & $\begin{array}{l}\text { Weight Percent } \\
\text { from GC }\end{array}$ & Area & $\begin{array}{c}\text { Weight in } \\
\text { injection }(\mu g)\end{array}$ & $\begin{array}{c}\text { Weight in } \\
\text { Sample (mg) }\end{array}$ & $\begin{array}{c}\text { Corrected Weight } \\
\text { in Sample (mg) }\end{array}$ & \begin{tabular}{|c|} 
Amount in \\
Moles (mmols)
\end{tabular} & $\begin{array}{l}\text { Weight } \\
\text { Percent }\end{array}$ \\
\hline $\mathrm{C}_{6 \text { (parafin) }}$ & 86.20 & 2.9188 & 66404 & 3.765 & 30.122 & 16.435 & 0.191 & 3.128 \\
\hline $\mathrm{C}_{7 \text { (parafin) }}$ & 100.23 & 10.0247 & 228066 & 14.111 & 112.888 & 61.594 & 0.615 & 11.721 \\
\hline $\mathrm{C}_{7 \text { (olefin) }}$ & 98.21 & 2.326 & 52918 & 2.902 & 23.218 & 12.668 & 0.129 & 2.411 \\
\hline $\mathrm{C}_{8 \text { (i-parafin) }}$ & 114.26 & 4.1712 & 94897 & 5.589 & 44.710 & 24.394 & 0.213 & 4.642 \\
\hline $\mathrm{C}_{8 \text { (parafin) }}$ & 114.26 & 10.5489 & 239992 & 14.874 & 118.993 & 64.925 & 0.568 & 12.355 \\
\hline $\mathrm{C}_{8 \text { (olefin) }}$ & 112.24 & 2.6916 & 61236 & 3.435 & 27.476 & 14.992 & 0.134 & 2.853 \\
\hline $\mathrm{C}_{9 \text { (i-parafin) }}$ & 128.29 & 2.6273 & 59772 & 3.341 & 26.727 & 14.583 & 0.114 & 2.775 \\
\hline $\mathrm{C}_{9 \text { (parafin) }}$ & 128.29 & 11.4025 & 259411 & 16.117 & 128.935 & 70.350 & 0.548 & 13.388 \\
\hline $\mathrm{C}_{9 \text { (olefin) }}$ & 126.27 & 1.182 & 26890 & 1.237 & 9.892 & 5.397 & 0.043 & 1.027 \\
\hline $\mathrm{C}_{10 \text { (parafin) }}$ & 142.32 & 8.8726 & 201854 & 12.434 & 99.468 & 54.272 & 0.381 & 10.328 \\
\hline $\mathrm{C}_{10 \text { (olefin) }}$ & 140.30 & 3.3261 & 74190 & 4.264 & 34.108 & 18.610 & 0.133 & 3.542 \\
\hline $\mathrm{C}_{11 \text { (parafin) }}$ & 156.35 & 6.7715 & 154054 & 9.375 & 74.996 & 40.919 & 0.262 & 7.787 \\
\hline $\mathrm{C}_{11 \text { (olefin) }}$ & 154.33 & 2.7561 & 62702 & 3.528 & 28.227 & 15.401 & 0.100 & 2.931 \\
\hline $\mathrm{C}_{12 \text { (parafin) }}$ & 170.38 & 4.9647 & 112949 & 6.744 & 53.952 & 29.437 & 0.173 & 5.602 \\
\hline $\mathrm{C}_{12 \text { (olefin) }}$ & 168.36 & 1.8274 & 41574 & 2.176 & 17.410 & 9.499 & 0.056 & 1.808 \\
\hline $\mathrm{C}_{13 \text { (parafin) }}$ & 184.41 & 4.3845 & 99750 & 5.899 & 47.194 & 25.750 & 0.140 & 4.900 \\
\hline $\mathrm{C}_{13 \text { (olefin) }}$ & 182.39 & 1.4406 & 32773 & 1.613 & 12.904 & 7.041 & 0.039 & 1.340 \\
\hline $\mathrm{C}_{14 \text { (parafin) }}$ & 198.44 & 2.9533 & 67188 & 3.815 & 30.523 & 16.654 & 0.084 & 3.169 \\
\hline $\mathrm{C}_{14 \text { (olefin) }}$ & 196.42 & 1.8224 & 41464 & 2.169 & 17.354 & 9.468 & 0.048 & 1.802 \\
\hline$C_{15 \text { (parafin) }}$ & 212.47 & 1.7134 & 38980 & 2.010 & 16.082 & 8.775 & 0.041 & 1.670 \\
\hline
\end{tabular}




\begin{tabular}{|l|r|r|r|r|r|r|r|r|}
\hline $\mathrm{C}_{16 \text { (parafin) }}$ & 226.50 & 1.0127 & 23040 & 0.990 & 7.921 & 4.322 & 0.019 & 0.822 \\
\hline $\mathrm{C}_{17 \text { (parafin) }}$ & 240.53 & 2.2792 & 51853 & 2.834 & 22.672 & 12.371 & 0.051 & 2.354 \\
\hline $\mathrm{C}_{17 \text { (olefin) }}$ & 238.51 & 0.4089 & 9303 & 0.111 & 0.888 & 0.485 & 0.002 & 0.092 \\
\hline
\end{tabular}


$6 \% \mathrm{Mo}, 32 \% \mathrm{Fe}, 0.8 \% \mathrm{Cu}, 0.9 \% \mathrm{~K}$

Injection Volume $(\mu \mathrm{L})$

\begin{tabular}{l|l}
0.1 & Total Volume $(\mu \mathrm{L})$
\end{tabular}

2550 Total Weight (mg)

\section{\begin{tabular}{l|l} 
Correction factor & 0.393434017 \\
\hline
\end{tabular}}

\begin{tabular}{|c|c|c|c|c|c|c|c|c|}
\hline Compound & MW & \begin{tabular}{|c|}
$\begin{array}{c}\text { Weight Percent } \\
\text { from GC }\end{array}$ \\
\end{tabular} & Area & $\begin{array}{c}\text { Weight in } \\
\text { injection }(\mu \mathrm{g})\end{array}$ & $\begin{array}{c}\text { Weight in } \\
\text { Sample (mg) }\end{array}$ & $\begin{array}{c}\text { Corrected Weight } \\
\text { in Sample (mg) }\end{array}$ & \begin{tabular}{|c|} 
Amount in \\
Moles (mmols) \\
\end{tabular} & $\begin{array}{l}\text { Weight } \\
\text { Percent } \\
\end{array}$ \\
\hline $\mathrm{C}_{6 \text { (parafin) }}$ & 86.20 & 3.2114 & 90542 & 5.310 & 135.405 & 53.273 & 0.618 & 3.600 \\
\hline$C_{7 \text { (parafin) }}$ & 100.23 & 16.1701 & 455894 & 28.691 & 731.621 & 287.845 & 2.872 & 19.450 \\
\hline $\mathrm{C}_{8 \text { (i-parafin) }}$ & 114.26 & 2.0792 & 58619 & 3.267 & 83.310 & 32.777 & 0.287 & 2.215 \\
\hline $\mathrm{C}_{8 \text { (parafin) }}$ & 114.26 & 15.8388 & 446551 & 28.093 & 716.374 & 281.846 & 2.467 & 19.045 \\
\hline $\mathrm{C}_{8 \text { (olefin) }}$ & 112.24 & 2.29 & 64562 & 3.647 & 93.008 & 36.593 & 0.326 & 2.473 \\
\hline$C_{9 \text { (parafin) }}$ & 128.29 & 11.9455 & 336785 & 21.069 & 537.248 & 211.372 & 1.648 & 14.283 \\
\hline $\mathrm{C}_{9 \text { (olefin) }}$ & 126.27 & 3.8185 & 107658 & 6.405 & 163.336 & 64.262 & 0.509 & 4.342 \\
\hline$C_{10 \text { (parafin) }}$ & 142.32 & 8.3771 & 236181 & 14.630 & 373.073 & 146.779 & 1.031 & 9.918 \\
\hline$C_{10 \text { (olefin) }}$ & 140.30 & 3.0461 & 85880 & 5.012 & 127.797 & 50.280 & 0.358 & 3.398 \\
\hline $\mathrm{C}_{11 \text { (parafin) }}$ & 156.35 & 5.3524 & 150902 & 9.173 & 233.906 & 92.027 & 0.589 & 6.218 \\
\hline $\mathrm{C}_{11 \text { (olefin) }}$ & 154.33 & 1.8583 & 52393 & 2.869 & 73.150 & 28.780 & 0.186 & 1.945 \\
\hline $\mathrm{C}_{12 \text { (parafin) }}$ & 170.38 & 3.4974 & 98604 & 5.826 & 148.561 & 58.449 & 0.343 & 3.950 \\
\hline $\mathrm{C}_{12 \text { (olefin) }}$ & 168.36 & 1.441 & 40626 & 2.116 & 53.947 & 21.225 & 0.126 & 1.434 \\
\hline $\mathrm{C}_{13 \text { (parafin) }}$ & 184.41 & 2.3312 & 65725 & 3.722 & 94.906 & 37.339 & 0.202 & 2.523 \\
\hline $\mathrm{C}_{13 \text { (olefin) }}$ & 182.39 & 1.0322 & 29102 & 1.378 & 35.141 & 13.826 & 0.076 & 0.934 \\
\hline $\mathrm{C}_{14 \text { (parafin) }}$ & 198.44 & 1.4788 & 41694 & 2.184 & 55.690 & 21.910 & 0.110 & 1.481 \\
\hline $\mathrm{C}_{14 \text { (olefin) }}$ & 196.42 & 0.6216 & 17526 & 0.637 & 16.250 & 6.393 & 0.033 & 0.432 \\
\hline$C_{15 \text { (parafin) }}$ & 212.47 & 0.8708 & 24647 & 1.093 & 27.871 & 10.965 & 0.052 & 0.741 \\
\hline $\mathrm{C}_{15 \text { (olefin) }}$ & 210.45 & 0.3466 & 9771 & 0.141 & 3.595 & 1.414 & 0.007 & 0.096 \\
\hline $\mathrm{C}_{16^{+}}+$ & 226.50 & 1.5132 & 42664 & 2.246 & 57.273 & 22.533 & 0.099 & 1.523 \\
\hline
\end{tabular}




\section{Appendix V}

\section{Data for Aqueous Phase}

for

Varied Cu Catalysts 
$6 \% \mathrm{Mo}, 16 \% \mathrm{Fe}, 0 \% \mathrm{Cu}, 0.9 \% \mathrm{~K}$

\begin{tabular}{|l|r|r|}
\hline Total Volume $(\mathrm{mL})$ & 1.5 & Sample Volume $(\mathrm{mL})$ \\
\hline
\end{tabular}

0.80 Total Weight $(\mathbf{m g})$

\begin{tabular}{|c|c|c|c|c|c|}
\hline $\mathbf{X}_{\text {standard }}$ & $A_{x, \text { standard }}$ & $\mathbf{A}_{\text {cyclohexanol, standard }}$ & $\mathbf{W t}_{\text {cyclohexanol, standard }}(\mu \mathrm{g})$ & $\mathbf{W t} \mathbf{t}_{\mathrm{x}, \text { standard }}(\boldsymbol{\mu g})$ & \\
\hline Methanol & 84286 & 19451 & 22.2 & 383.7 & \\
\hline Ethanol & 82843 & 16693 & 18.3 & 225.6 & \\
\hline 2-Propanol & 12534417 & 290032 & 5.8 & 816.1 & \\
\hline 1-Propanol & 78959 & 16539 & 19.5 & 305.1 & \\
\hline 2-Butanol & 31995228 & 1832669 & 34.2 & 796.5 & \\
\hline 1-Butanol & 82482 & 18344 & 18.1 & 391.4 & \\
\hline 2-Pentanol & 41499452 & 135882 & 21 & 783.9 & \\
\hline 1-Pentanol & 77869 & 19888 & 18.8 & 388.3 & \\
\hline $\mathbf{X}_{\text {sample }}$ & $\mathbf{A}_{\mathrm{x}, \text { sample }}$ & $A_{\text {corrected, } x, \text { sample }}$ & $A_{\text {cyclohexanol, sample }}$ & $\mathbf{W t}_{\text {cyclohexanol, sample }}(\mu \mathrm{g})$ & $\mathbf{W t}_{\mathrm{x}, \text { sample }}(\mu \mathrm{g})$ \\
\hline Methanol & 2629424 & 18384837.7 & 4072613 & 32500 & 83694.4 \\
\hline Ethanol & 7960369 & 57946434.8 & 4072613 & 32500 & 157801.1 \\
\hline 2-Propanol & 1325732 & 529034361.3 & 4072613 & 32500 & 34444.8 \\
\hline 1-Propanol & 3002166 & 20319805.9 & 4072613 & 32500 & 78516.4 \\
\hline 2-Butanol & 894953 & 382708734.0 & 4072613 & 32500 & 9527.3 \\
\hline 1-Butanol & 1975408 & 15976531.2 & 4072613 & 32500 & 75813.1 \\
\hline 2-Pentanol & & 0.0 & 4072613 & 32500 & 0.0 \\
\hline 1-Pentanol & 4648867 & 39245566.4 & 4072613 & 32500 & 195701.2 \\
\hline & MW & Weight (mg) & $\mathrm{mmol}_{\text {sample }}$ & & \\
\hline Methanol & 32.04 & 156.927 & 4.898 & & \\
\hline Ethanol & 46.07 & 295.877 & 6.422 & & \\
\hline 2-Propanol & 60.10 & 64.584 & 1.075 & & \\
\hline 1-Propanol & 60.10 & 147.218 & 2.450 & \multirow{3}{*}{$\begin{array}{c}\text { Total Oxygenate } \\
\text { Weight (mg) (based on } \\
\text { sample volume) }\end{array}$} & \multirow{3}{*}{635.50} \\
\hline 2-Butanol & 74.13 & 17.864 & 0.241 & & \\
\hline 1-Butanol & 74.13 & 142.150 & 1.918 & & \\
\hline 2-Pentanol & 88.16 & 0.000 & 0.000 & \multirow{3}{*}{$\begin{array}{c}\text { Total Oxygenate } \\
\text { Weight (mg) (based on } \\
\text { total volume) }\end{array}$} & \multirow{3}{*}{1191.56} \\
\hline 1-Pentanol & 88.16 & 366.940 & 4.162 & & \\
\hline Water & 18.01 & 258.441 & 14.350 & & \\
\hline
\end{tabular}


$6 \% \mathrm{Mo}, 16 \% \mathrm{Fe}, 0.4 \% \mathrm{Cu}, 0.9 \% \mathrm{~K}$ \begin{tabular}{|l|r|r|}
\hline Total Volume $(\mathrm{mL})$ & 1.5 & Sample Volume $(\mathrm{mL})$ \\
\hline
\end{tabular}

\begin{tabular}{|c|c|c|c|c|c|}
\hline $\mathrm{X}_{\text {standard }}$ & $A_{x, \text { standard }}$ & $\mathrm{A}_{\text {cyclohexanol, standard }}$ & $\mathrm{Wt}_{\text {cyclohexanol, standard }}(\mu \mathrm{g})$ & $\mathbf{W t}_{\mathrm{x}, \text { standard }}(\mu \mathrm{g})$ & \\
\hline Methanol & 84286 & 19451 & 22.2 & 383.7 & \\
\hline Ethanol & 82843 & 16693 & 18.3 & 225.6 & \\
\hline 2-Propanol & 12534417 & 290032 & 5.8 & 816.1 & \\
\hline 1-Propanol & 78959 & 16539 & 19.5 & 305.1 & \\
\hline 2-Butanol & 31995228 & 1832669 & 34.2 & 796.5 & \\
\hline 1-Butanol & 82482 & 18344 & 18.1 & 391.4 & \\
\hline 2-Pentanol & 41499452 & 135882 & 21 & 783.9 & \\
\hline 1-Pentanol & 77869 & 19888 & 18.8 & 388.3 & \\
\hline $\mathbf{X}_{\text {sample }}$ & $\mathbf{A}_{\mathbf{x}, \text { sample }}$ & $\mathrm{A}_{\text {corrected,x, sample }}$ & $\mathbf{A}_{\text {cyclohexanol, sample }}$ & $\mathrm{Wt}_{\text {cyclohexanol, sample }}(\mu \mathrm{g})$ & $\mathrm{Wt}_{\mathrm{x}, \text { sample }}(\mu \mathrm{g})$ \\
\hline Methanol & 2651079 & 32725601.0 & 1447952 & 20400 & 148978.6 \\
\hline Ethanol & 7260776 & 93313041.4 & 1447952 & 20400 & 254112.3 \\
\hline 2-Propanol & 950885 & 669918425.3 & 1447952 & 20400 & 43617.5 \\
\hline 1-Propanol & 1814886 & 21687025.4 & 1447952 & 20400 & 83799.3 \\
\hline 2-Butanol & 536600 & 405120852.9 & 1447952 & 20400 & 10085.2 \\
\hline 1-Butanol & 1123443 & 16041409.0 & 1447952 & 20400 & 76120.9 \\
\hline 2-Pentanol & 124762 & 11373679.0 & 1447952 & 20400 & 214.8 \\
\hline \multirow[t]{2}{*}{ 1-Pentanol } & 403851 & 6019084.3 & 1447952 & 20400 & 30014.6 \\
\hline & MW & Weight (mg) & $\mathrm{mmol}_{\text {sample }}$ & & \\
\hline Methanol & 32.04 & 223.468 & 6.975 & & \\
\hline Ethanol & 46.07 & 381.168 & 8.274 & & \\
\hline 2-Propanol & 60.10 & 65.426 & 1.089 & & \\
\hline 1-Propanol & 60.10 & 125.699 & 2.091 & \multirow{3}{*}{$\begin{array}{c}\text { Total Oxygenate } \\
\text { Weight (mg) (based on } \\
\text { sample volume) }\end{array}$} & \multirow{3}{*}{646.94} \\
\hline 2-Butanol & 74.13 & 15.128 & 0.204 & & \\
\hline 1-Butanol & 74.13 & 114.181 & 1.540 & & \\
\hline 2-Pentanol & 88.16 & 0.322 & 0.004 & \multirow{3}{*}{$\begin{array}{c}\text { Total Oxygenate } \\
\text { Weight (mg) (based on } \\
\text { total volume) }\end{array}$} & \multirow{3}{*}{970.42} \\
\hline 1-Pentanol & 88.16 & 45.022 & 0.511 & & \\
\hline Water & 18.01 & 379.585 & 21.076 & & \\
\hline & & & & $\begin{array}{c}\text { Weight Percent of } \\
\text { Water }\end{array}$ & 28.12 \\
\hline
\end{tabular}


$6 \% \mathrm{Mo}, 16 \% \mathrm{Fe}, 1.6 \% \mathrm{Cu}, 0.9 \% \mathrm{~K}$ \begin{tabular}{|l|l|l|}
\hline Total Volume $(\mathrm{mL})$ & 0.8 & Sample Volume $(\mathrm{mL})$ \\
\hline
\end{tabular}

\begin{tabular}{|c|c|c|c|c|c|}
\hline $\mathbf{X}_{\text {standard }}$ & $A_{x, \text { standard }}$ & $A_{\text {cyclohexanol, standard }}$ & $\mathrm{Wt}_{\text {cyclohexanol, standard }}(\mu \mathrm{g})$ & $\mathrm{Wt}_{\mathrm{x}, \text { standard }}(\mu \mathrm{g})$ & \\
\hline Methanol & 84286 & 19451 & 22.2 & 383.7 & \\
\hline Ethanol & 82843 & 16693 & 18.3 & 225.6 & \\
\hline 2-Propanol & 12534417 & 290032 & 5.8 & 816.1 & \\
\hline 1-Propanol & 78959 & 16539 & 19.5 & 305.1 & \\
\hline 2-Butanol & 31995228 & 1832669 & 34.2 & 796.5 & \\
\hline 1-Butanol & 82482 & 18344 & 18.1 & 391.4 & \\
\hline 2-Pentanol & 41499452 & 135882 & 21 & 783.9 & \\
\hline 1-Pentanol & 77869 & 19888 & 18.8 & 388.3 & \\
\hline $\mathbf{X}_{\text {sample }}$ & $A_{x, \text { sample }}$ & $A_{\text {corrected, } x, \text { sample }}$ & A cyclohexanol, sample & $\mathrm{Wt}_{\text {cyclohexanol, sample }}(\mu \mathrm{g})$ & $\mathbf{W t}_{\mathbf{x}, \text { sample }}(\mu \mathrm{g})$ \\
\hline Methanol & 2405140 & 21332994.4 & 2765894 & 28000 & 97115.4 \\
\hline Ethanol & 6743497 & 62271735.8 & 2765894 & 28000 & 169579.9 \\
\hline 2-Propanol & 948178 & 479987908.8 & 2765894 & 28000 & 31251.4 \\
\hline 1-Propanol & 1818540 & 15614209.2 & 2765894 & 28000 & 60333.8 \\
\hline 2-Butanol & 697644 & 378455037.4 & 2765894 & 28000 & 9421.4 \\
\hline 1-Butanol & 1402161 & 14385860.7 & 2765894 & 28000 & 68264.9 \\
\hline 2-Pentanol & 256919 & 16829118.1 & 2765894 & 28000 & 317.9 \\
\hline \multirow[t]{2}{*}{ 1-Pentanol } & 791512 & 8476435.6 & 2765894 & 28000 & 42268.4 \\
\hline & MW & Weight (mg) & $\mathrm{mmol}_{\text {sample }}$ & & \\
\hline Methanol & 32.04 & 110.989 & 3.464 & & \\
\hline Ethanol & 46.07 & 193.806 & 4.207 & & \\
\hline 2-Propanol & 60.10 & 35.716 & 0.594 & & \\
\hline 1-Propanol & 60.10 & 68.953 & 1.147 & \multirow{3}{*}{$\begin{array}{c}\text { Total Oxygenate } \\
\text { Weight (mg) (based on } \\
\text { sample volume) }\end{array}$} & \multirow{3}{*}{478.55} \\
\hline 2-Butanol & 74.13 & 10.767 & 0.145 & & \\
\hline 1-Butanol & 74.13 & 78.017 & 1.052 & & \\
\hline 2-Pentanol & 88.16 & 0.363 & 0.004 & \multirow{3}{*}{$\begin{array}{c}\text { Total Oxygenate } \\
\text { Weight (mg) (based on } \\
\text { total volume) }\end{array}$} & \multirow{3}{*}{546.92} \\
\hline 1-Pentanol & 88.16 & 48.307 & 0.548 & & \\
\hline Water & 18.01 & 170.282 & 9.455 & & \\
\hline & & & & $\begin{array}{c}\text { Weight Percent of } \\
\text { Water }\end{array}$ & 23.74 \\
\hline
\end{tabular}


Appendix VI

\author{
Data for Oil Phase \\ for \\ Varied Cu Catalysts
}


$6 \% \mathrm{Mo}, 16 \% \mathrm{Fe}, 0 \% \mathrm{Cu}, 0.9 \% \mathrm{~K}$

\begin{tabular}{|c|c|c|c|c|c|c|c|c|}
\hline \multirow{2}{*}{\multicolumn{2}{|c|}{$\begin{array}{c}\text { Injection Volume }(\mu \mathrm{L}) \\
\text { Correction factor }\end{array}$}} & 0.1 & \multicolumn{2}{|c|}{ Total Volume $(\mu \mathrm{L})$} & \multicolumn{2}{|c|}{\begin{tabular}{l|l|}
1000 & Total Weight $(\mathrm{mg})$ \\
\end{tabular}} & \multicolumn{2}{|l|}{900} \\
\hline & & 0.807249237 & & & & & & \\
\hline Compound & MW & $\begin{array}{l}\text { Weight Percent } \\
\text { from GC }\end{array}$ & Area & $\begin{array}{c}\text { Weight in } \\
\text { injection }(\mu \mathrm{g})\end{array}$ & $\begin{array}{c}\text { Weight in } \\
\text { Sample (mg) }\end{array}$ & $\begin{array}{c}\text { Corrected Weight } \\
\text { in Sample (mg) }\end{array}$ & $\begin{array}{c}\text { Amount in } \\
\text { Moles (mmols) }\end{array}$ & $\begin{array}{l}\text { Weight } \\
\text { Percent }\end{array}$ \\
\hline $\mathrm{C}_{6 \text { (parafin) }}$ & 86.20 & 3.3005 & 80436 & 4.663 & 46.633 & 37.644 & 0.437 & 4.227 \\
\hline $\mathrm{C}_{7 \text { (parafin) }}$ & 100.23 & 10.8628 & 264734 & 16.458 & 164.576 & 132.854 & 1.325 & 14.918 \\
\hline $\mathrm{C}_{7 \text { (olefin) }}$ & 98.21 & 1.4171 & 34535 & 1.726 & 17.258 & 13.931 & 0.142 & 1.564 \\
\hline $\mathrm{C}_{8 \text { (i-parafin) }}$ & 114.26 & 1.8641 & 45429 & 2.423 & 24.229 & 19.559 & 0.171 & 2.196 \\
\hline $\mathrm{C}_{8 \text { (parafin) }}$ & 114.26 & 12.6777 & 308965 & 19.288 & 192.882 & 155.704 & 1.363 & 17.484 \\
\hline $\mathrm{C}_{8 \text { (olefin) }}$ & 112.24 & 1.3204 & 32179 & 1.575 & 15.750 & 12.714 & 0.113 & 1.428 \\
\hline $\mathrm{C}_{9 \text { (i-parafin) }}$ & 128.29 & 1.1822 & 28812 & 1.360 & 13.595 & 10.975 & 0.086 & 1.232 \\
\hline $\mathrm{C}_{9 \text { (parafin) }}$ & 128.29 & 10.2082 & 248782 & 15.437 & 154.367 & 124.613 & 0.971 & 13.993 \\
\hline$C_{9 \text { (olefin) }}$ & 126.27 & 1.5706 & 38277 & 1.965 & 19.653 & 15.864 & 0.126 & 1.781 \\
\hline$C_{10 \text { (parafin) }}$ & 142.32 & 7.1482 & 174207 & 10.664 & 106.642 & 86.087 & 0.605 & 9.667 \\
\hline $\mathrm{C}_{10 \text { (olefin) }}$ & 140.30 & 2.2265 & 54261 & 2.988 & 29.882 & 24.122 & 0.172 & 2.709 \\
\hline $\mathrm{C}_{11 \text { (parafin) }}$ & 156.35 & 4.987 & 121535 & 7.293 & 72.934 & 58.876 & 0.377 & 6.611 \\
\hline $\mathrm{C}_{11 \text { (olefin) }}$ & 154.33 & 1.7479 & 42598 & 2.242 & 22.418 & 18.097 & 0.117 & 2.032 \\
\hline $\mathrm{C}_{12 \text { (parafin) }}$ & 170.38 & 3.4596 & 84312 & 4.911 & 49.113 & 39.646 & 0.233 & 4.452 \\
\hline $\mathrm{C}_{12 \text { (olefin) }}$ & 168.36 & 1.1235 & 27382 & 1.268 & 12.680 & 10.236 & 0.061 & 1.149 \\
\hline $\mathrm{C}_{13 \text { (parafin) }}$ & 184.41 & 2.6928 & 65626 & 3.715 & 37.155 & 29.993 & 0.163 & 3.368 \\
\hline $\mathrm{C}_{13 \text { (olefin) }}$ & 182.39 & 0.8751 & 21326 & 0.880 & 8.805 & 7.107 & 0.039 & 0.798 \\
\hline $\mathrm{C}_{14 \text { (parafin) }}$ & 198.44 & 2.3507 & 57289 & 3.182 & 31.819 & 25.686 & 0.129 & 2.884 \\
\hline $\mathrm{C}_{14 \text { (olefin) }}$ & 196.42 & 0.9203 & 22428 & 0.951 & 9.510 & 7.677 & 0.039 & 0.862 \\
\hline $\mathrm{C}_{15 \text { (parafin) }}$ & 212.47 & 2.7779 & 67699 & 3.848 & 38.481 & 31.064 & 0.146 & 3.488 \\
\hline $\mathrm{C}_{15 \text { (olefin) }}$ & 210.45 & 1.3047 & 31796 & 1.550 & 15.505 & 12.516 & 0.059 & 1.405 \\
\hline
\end{tabular}




\begin{tabular}{|l|r|r|r|r|r|r|r|r|}
\hline $\mathrm{C}_{16 \text { (parafin) }}$ & 226.50 & 1.547 & 37702 & 1.928 & 19.285 & 15.567 & 0.069 & 1.748 \\
\hline $\mathrm{C}_{16 \text { (olefin) }}$ & 224.48 & 1.4575 & 35521 & 1.789 & 17.889 & 14.441 & 0.064 & 1.622 \\
\hline $\mathrm{C}_{17^{+}}$ & 240.53 & 0.7853 & 19139 & 0.740 & 7.405 & 5.978 & 0.025 & 0.671 \\
\hline
\end{tabular}


$6 \% \mathrm{Mo}, 16 \% \mathrm{Fe}, 0.4 \% \mathrm{Cu}, 0.9 \% \mathrm{~K}$

\begin{tabular}{|c|c|c|c|c|c|c|c|c|}
\hline \multirow{2}{*}{\multicolumn{2}{|c|}{$\frac{\text { Injection Volume }(\mu \mathrm{L})}{\text { Correction factor }}$}} & \multirow{3}{*}{$\begin{array}{r}0.1 \\
0.326860828 \\
\begin{array}{c}\text { Weight Percent } \\
\text { from GC }\end{array}\end{array}$} & \multicolumn{2}{|c|}{ Total Volume $(\mu \mathrm{L})$} & \multicolumn{2}{|c|}{\begin{tabular}{l|l|}
1000 & Total Weight $(\mathrm{mg})$ \\
\end{tabular}} & \multicolumn{2}{|l|}{950} \\
\hline & & & & & & & & \\
\hline Compound & MW & & Area & $\begin{array}{c}\text { Weight in } \\
\text { injection }(\mu \mathrm{g})\end{array}$ & $\begin{array}{c}\text { Weight in } \\
\text { Sample (mg) }\end{array}$ & $\begin{array}{l}\text { Corrected Weight } \\
\text { in Sample (mg) }\end{array}$ & $\begin{array}{c}\text { Amount in } \\
\text { Moles (mmols) }\end{array}$ & $\begin{array}{l}\text { Weight } \\
\text { Percent }\end{array}$ \\
\hline $\mathrm{C}_{6 \text { (parafin) }}$ & 86.20 & 3.5371 & 161179 & 9.830 & 98.305 & 32.132 & 0.373 & 3.748 \\
\hline $\mathrm{C}_{7 \text { (i-parafin) }}$ & 99.23 & 0.8682 & 39564 & 2.048 & 20.476 & 6.693 & 0.067 & 0.781 \\
\hline $\mathrm{C}_{7 \text { (parafin) }}$ & 100.23 & 11.5858 & 527942 & 33.302 & 333.018 & 108.851 & 1.086 & 12.696 \\
\hline $\mathrm{C}_{7 \text { (olefin) }}$ & 98.21 & 0.7068 & 32205 & 1.577 & 15.767 & 5.154 & 0.052 & 0.601 \\
\hline $\mathrm{C}_{8 \text { (i-parafin) }}$ & 113.26 & 2.0804 & 94798 & 5.582 & 55.824 & 18.247 & 0.161 & 2.128 \\
\hline $\mathrm{C}_{8 \text { (parafin) }}$ & 114.26 & 15.4151 & 702434 & 44.469 & 444.686 & 145.350 & 1.272 & 16.953 \\
\hline $\mathrm{C}_{8 \text { (olefin) }}$ & 112.24 & 1.8852 & 85903 & 5.013 & 50.131 & 16.386 & 0.146 & 1.911 \\
\hline $\mathrm{C}_{9 \text { (i-parafin) }}$ & 128.29 & 1.3373 & 60938 & 3.415 & 34.155 & 11.164 & 0.087 & 1.302 \\
\hline $\mathrm{C}_{9 \text { (parafin) }}$ & 128.29 & 13.1524 & 599325 & 37.870 & 378.700 & 123.782 & 0.965 & 14.438 \\
\hline $\mathrm{C}_{9 \text { (olefin) }}$ & 126.27 & 2.3088 & 105209 & 6.249 & 62.486 & 20.424 & 0.162 & 2.382 \\
\hline $\mathrm{C}_{10 \text { (parafin) }}$ & 142.32 & 9.9107 & 451608 & 28.417 & 284.167 & 92.883 & 0.653 & 10.834 \\
\hline $\mathrm{C}_{10 \text { (olefin) }}$ & 140.30 & 3.054 & 139163 & 8.422 & 84.215 & 27.527 & 0.196 & 3.211 \\
\hline $\mathrm{C}_{11 \text { (parafin) }}$ & 156.35 & 6.9129 & 315008 & 19.675 & 196.749 & 64.310 & 0.411 & 7.501 \\
\hline $\mathrm{C}_{11 \text { (olefin) }}$ & 154.33 & 2.1269 & 96919 & 5.718 & 57.181 & 18.690 & 0.121 & 2.180 \\
\hline $\mathrm{C}_{12 \text { (parafin) }}$ & 170.38 & 4.8858 & 222639 & 13.764 & 137.637 & 44.988 & 0.264 & 5.247 \\
\hline $\mathrm{C}_{12 \text { (olefin) }}$ & 168.36 & 1.6164 & 73658 & 4.229 & 42.295 & 13.825 & 0.082 & 1.612 \\
\hline $\mathrm{C}_{13 \text { (parafin) }}$ & 184.41 & 3.6225 & 165068 & 10.079 & 100.794 & 32.945 & 0.179 & 3.843 \\
\hline $\mathrm{C}_{13 \text { (olefin) }}$ & 182.39 & 1.2083 & 55061 & 3.039 & 30.394 & 9.934 & 0.054 & 1.159 \\
\hline $\mathrm{C}_{14 \text { (parafin) }}$ & 198.44 & 2.7544 & 125514 & 7.548 & 75.481 & 24.672 & 0.124 & 2.878 \\
\hline $\mathrm{C}_{14 \text { (olefin) }}$ & 196.42 & 0.9018 & 41096 & 2.146 & 21.457 & 7.013 & 0.036 & 0.818 \\
\hline
\end{tabular}




\begin{tabular}{|l|r|r|r|r|r|r|r|r|}
\hline $\mathrm{C}_{15 \text { (parafin) }}$ & 212.47 & 1.9221 & 87587 & 5.121 & 51.209 & 16.738 & 0.079 & 1.952 \\
\hline $\mathrm{C}_{15 \text { (olefin) }}$ & 210.45 & 0.6681 & 30446 & 1.464 & 14.641 & 4.786 & 0.023 & 0.558 \\
\hline $\mathrm{C}_{16 \text { (parafin) }}$ & 226.50 & 1.3053 & 59478 & 3.322 & 33.220 & 10.858 & 0.048 & 1.267 \\
\hline $\mathrm{C}_{16 \text { (olefin) }}$ & 224.48 & 0.5189 & 23646 & 1.029 & 10.289 & 3.363 & 0.015 & 0.392 \\
\hline $\mathrm{C}_{17}{ }^{2}$ & 240.53 & 1.8009 & 82065 & 4.768 & 47.675 & 15.583 & 0.065 & 1.818 \\
\hline \multicolumn{10}{|c|}{ Total } & 262.299 & 2622.986 & 357.351 & 6.642 & 100.000 \\
\hline
\end{tabular}


$6 \% \mathrm{Mo}, 16 \% \mathrm{Fe}, 1.6 \% \mathrm{Cu}, 0.9 \% \mathrm{~K}$ Injection Volume $(\mu \mathrm{L})$

\begin{tabular}{c|c}
0.1 & Total Volume $(\mu \mathrm{L})$ \\
\hline
\end{tabular}

1200 Total Weight (mg)

\section{\begin{tabular}{|l|l|} 
Correction factor & 0.321119469 \\
\hline
\end{tabular}}

\begin{tabular}{|c|c|c|c|c|c|c|c|c|}
\hline Compound & MW & \begin{tabular}{|c|}
$\begin{array}{c}\text { Weight Percent } \\
\text { from GC }\end{array}$ \\
\end{tabular} & Area & $\begin{array}{c}\text { Weight in } \\
\text { injection }(\mu \mathrm{g})\end{array}$ & $\begin{array}{c}\text { Weight in } \\
\text { Sample (mg) }\end{array}$ & \begin{tabular}{|c|}
$\begin{array}{c}\text { Corrected Weight } \\
\text { in Sample (mg) }\end{array}$ \\
\end{tabular} & \begin{tabular}{|c|} 
Amount in \\
Moles (mmols) \\
\end{tabular} & $\begin{array}{l}\text { Weight } \\
\text { Percent }\end{array}$ \\
\hline $\mathrm{C}_{6 \text { (parafin) }}$ & 86.20 & 7.5541 & 307955 & 19.224 & 230.682 & 74.077 & 0.859 & 8.339 \\
\hline $\mathrm{C}_{7 \text { (i-parafin) }}$ & 100.23 & 1.9492 & 79463 & 4.601 & 55.212 & 17.730 & 0.177 & 1.996 \\
\hline $\mathrm{C}_{7 \text { (parafin) }}$ & 100.23 & 13.7958 & 562404 & 35.507 & 426.087 & 136.825 & 1.365 & 15.402 \\
\hline $\mathrm{C}_{7 \text { (olefin) }}$ & 98.21 & 1.2727 & 51885 & 2.836 & 34.033 & 10.929 & 0.111 & 1.230 \\
\hline $\mathrm{C}_{8 \text { (i-parafin) }}$ & 114.26 & 2.2517 & 91796 & 5.390 & 64.683 & 20.771 & 0.182 & 2.338 \\
\hline $\mathrm{C}_{8 \text { (parafin) }}$ & 114.26 & 14.6101 & 595605 & 37.632 & 451.584 & 145.012 & 1.269 & 16.324 \\
\hline $\mathrm{C}_{8 \text { (olefin) }}$ & 112.24 & 1.7458 & 71169 & 4.070 & 48.842 & 15.684 & 0.140 & 1.766 \\
\hline $\mathrm{C}_{9 \text { (i-parafin) }}$ & 128.29 & 1.332 & 54300 & 2.991 & 35.888 & 11.524 & 0.090 & 1.297 \\
\hline $\mathrm{C}_{9 \text { (parafin) }}$ & 128.29 & 11.9283 & 486272 & 30.635 & 367.621 & 118.050 & 0.920 & 13.289 \\
\hline $\mathrm{C}_{9 \text { (olefin) }}$ & 126.27 & 2.0842 & 84963 & 4.953 & 59.436 & 19.086 & 0.151 & 2.148 \\
\hline $\mathrm{C}_{10 \text { (parafin) }}$ & 142.32 & 8.4194 & 343228 & 21.481 & 257.770 & 82.775 & 0.582 & 9.318 \\
\hline $\mathrm{C}_{10 \text { (olefin) }}$ & 140.30 & 2.6297 & 107203 & 6.376 & 76.515 & 24.570 & 0.175 & 2.766 \\
\hline $\mathrm{C}_{11 \text { (parafin) }}$ & 156.35 & 5.8297 & 237657 & 14.725 & 176.697 & 56.741 & 0.363 & 6.387 \\
\hline $\mathrm{C}_{11 \text { (olefin) }}$ & 154.33 & 1.9283 & 78609 & 4.546 & 54.556 & 17.519 & 0.114 & 1.972 \\
\hline $\mathrm{C}_{12 \text { (parafin) }}$ & 170.38 & 4.0273 & 164179 & 10.022 & 120.270 & 38.621 & 0.227 & 4.347 \\
\hline $\mathrm{C}_{12 \text { (olefin) }}$ & 168.36 & 1.2054 & 49138 & 2.660 & 31.924 & 10.251 & 0.061 & 1.154 \\
\hline $\mathrm{C}_{13 \text { (parafin) }}$ & 184.41 & 2.7937 & 113889 & 6.804 & 81.649 & 26.219 & 0.142 & 2.951 \\
\hline $\mathrm{C}_{13 \text { (olefin) }}$ & 182.39 & 0.7859 & 32040 & 1.566 & 18.793 & 6.035 & 0.033 & 0.679 \\
\hline $\mathrm{C}_{14 \text { (parafin) }}$ & 198.44 & 1.8887 & 76996 & 4.443 & 53.317 & 17.121 & 0.086 & 1.927 \\
\hline $\mathrm{C}_{14 \text { (olefin) }}$ & 196.42 & 0.4707 & 19191 & 0.744 & 8.926 & 2.866 & 0.015 & 0.323 \\
\hline
\end{tabular}




\begin{tabular}{|l|r|r|r|r|r|r|r|r|}
\hline $\mathrm{C}_{15 \text { (parafin) }}$ & 212.47 & 1.3661 & 55690 & 3.080 & 36.955 & 11.867 & 0.056 & 1.336 \\
\hline $\mathrm{C}_{15 \text { (olefin) }}$ & 210.45 & 0.313 & 12764 & 0.333 & 3.990 & 1.281 & 0.006 & 0.144 \\
\hline $\mathrm{C}_{16}{ }^{+}$ & 226.50 & 2.4532 & 100008 & 5.916 & 70.989 & 22.796 & 0.101 & 2.566 \\
\hline
\end{tabular}




\section{Appendix VII}

Data for Aqueous Phase

for

Varied K Catalysts 
$6 \% \mathrm{Mo}, 16 \% \mathrm{Fe}, 0.9 \% \mathrm{Cu}, 0 \% \mathrm{~K}$ \begin{tabular}{|l|l|l|}
\hline Total Volume $(\mathrm{mL})$ & 1.5 & Sample Volume $(\mathrm{mL})$ \\
\hline
\end{tabular}

\begin{tabular}{|c|c|c|c|c|c|}
\hline $\mathrm{X}_{\text {standard }}$ & $A_{x, \text { standard }}$ & $\mathrm{A}_{\text {cyclohexanol, standard }}$ & $\mathrm{Wt}_{\text {cyclohexanol, standard }}(\boldsymbol{\mu g})$ & $\mathbf{W t}_{\mathrm{x}, \text { standard }}(\mu \mathrm{g})$ & \\
\hline Methanol & 84286 & 19451 & 22.2 & 383.7 & \\
\hline Ethanol & 82843 & 16693 & 18.3 & 225.6 & \\
\hline 2-Propanol & 12534417 & 290032 & 5.8 & 816.1 & \\
\hline 1-Propanol & 78959 & 16539 & 19.5 & 305.1 & \\
\hline 2-Butanol & 31995228 & 1832669 & 34.2 & 796.5 & \\
\hline 1-Butanol & 82482 & 18344 & 18.1 & 391.4 & \\
\hline 2-Pentanol & 41499452 & 135882 & 21 & 783.9 & \\
\hline 1-Pentanol & 77869 & 19888 & 18.8 & 388.3 & \\
\hline $\mathbf{X}_{\text {sample }}$ & $\mathbf{A}_{\mathbf{x}, \text { sample }}$ & A corrected, $\mathbf{x}$, sample & A cyclohexanol, sample $_{\text {cal }}$ & $\mathbf{W t}_{\text {cyclohexanol, sample }}(\mu \mathrm{g})$ & $\mathbf{W t}_{\mathrm{x}, \text { sample }}(\mu \mathrm{g})$ \\
\hline Methanol & 1543133 & 14599075.6 & 1435485 & 15500 & 66460.2 \\
\hline Ethanol & 1600581 & 15765000.9 & 1435485 & 15500 & 42931.6 \\
\hline 2-Propanol & 45167 & 24387776.6 & 1435485 & 15500 & 1587.9 \\
\hline 1-Propanol & 290260 & 2658244.1 & 1435485 & 15500 & 10271.5 \\
\hline 2-Butanol & 33615 & 19450200.5 & 1435485 & 15500 & 484.2 \\
\hline 1-Butanol & 89761 & 982282.0 & 1435485 & 15500 & 4661.2 \\
\hline 2-Pentanol & & 0.0 & 1435485 & 15500 & 0.0 \\
\hline \multirow[t]{2}{*}{ 1-Pentanol } & 23104 & 263908.6 & 1435485 & 15500 & 1316.0 \\
\hline & MW & Weight (mg) & $\mathrm{mmol}_{\text {sample }}$ & & \\
\hline Methanol & 32.04 & 124.613 & 3.889 & & \\
\hline Ethanol & 46.07 & 80.497 & 1.747 & & \\
\hline 2-Propanol & 60.10 & 2.977 & 0.050 & \multirow{3}{*}{$\begin{array}{c}\text { Total Oxygenate } \\
\text { Weight (mg) (based on } \\
\text { sample volume) }\end{array}$} & \multirow{3}{*}{127.71} \\
\hline 1-Propanol & 60.10 & 19.259 & 0.320 & & \\
\hline 2-Butanol & 74.13 & 0.908 & 0.012 & & \\
\hline 1-Butanol & 74.13 & 8.740 & 0.118 & \multirow{3}{*}{$\begin{array}{c}\text { Total Oxygenate } \\
\text { Weight (mg) (based on } \\
\text { total volume) }\end{array}$} & \multirow{3}{*}{239.46} \\
\hline 2-Pentanol & 88.16 & 0.000 & 0.000 & & \\
\hline 1-Pentanol & 88.16 & 2.468 & 0.028 & & \\
\hline Water & 18.01 & 1000.539 & 55.555 & $\begin{array}{c}\text { Weight Percent of } \\
\text { Water }\end{array}$ & 80.69 \\
\hline
\end{tabular}


$6 \% \mathrm{Mo}, 16 \% \mathrm{Fe}, 0.8 \% \mathrm{Cu}, 0.45 \% \mathrm{~K}$ \begin{tabular}{|l|r|r|}
\hline Total Volume $(\mathrm{mL})$ & 2.35 & Sample Volume $(\mathrm{mL})$ \\
\hline
\end{tabular}

\begin{tabular}{|c|c|c|c|c|c|}
\hline $\mathbf{X}_{\text {standard }}$ & $A_{x, \text { standard }}$ & $\mathbf{A}_{\text {cyclohexanol, standard }}$ & $\mathrm{Wt}_{\text {cyclohexanol, standard }}(\mu \mathrm{g})$ & $\mathbf{W t}_{\mathrm{x}, \text { standard }}(\mu \mathrm{g})$ & \\
\hline Methanol & 84286 & 19451 & 22.2 & 383.7 & \\
\hline Ethanol & 82843 & 16693 & 18.3 & 225.6 & \\
\hline 2-Propanol & 12534417 & 290032 & 5.8 & 816.1 & \\
\hline 1-Propanol & 78959 & 16539 & 19.5 & 305.1 & \\
\hline 2-Butanol & 31995228 & 1832669 & 34.2 & 796.5 & \\
\hline 1-Butanol & 82482 & 18344 & 18.1 & 391.4 & \\
\hline 2-Pentanol & 41499452 & 135882 & 21 & 783.9 & \\
\hline 1-Pentanol & 77869 & 19888 & 18.8 & 388.3 & \\
\hline $\mathbf{X}_{\text {sample }}$ & $A_{x, \text { sample }}$ & $\mathbf{A}_{\text {corrected, } x \text {, sample }}$ & $\mathbf{A}_{\text {cyclohexanol, sample }}$ & $\mathbf{W t}_{\text {cyclohexanol, sample }}(\mu \mathrm{g})$ & $\mathbf{W t}_{\mathrm{x}, \text { sample }}(\mu \mathrm{g})$ \\
\hline Methanol & 2661786 & 3404105.9 & 15688973 & 22900 & 15496.7 \\
\hline Ethanol & 4733160 & 6301957.3 & 15688973 & 22900 & 17161.6 \\
\hline 2-Propanol & 371253 & 27097477.4 & 15688973 & 22900 & 1764.3 \\
\hline 1-Propanol & 546127 & 676097.4 & 15688973 & 22900 & 2612.5 \\
\hline 2-Butanol & 238480 & 18653093.1 & 15688973 & 22900 & 464.4 \\
\hline 1-Butanol & 479889 & 709900.1 & 15688973 & 22900 & 3368.7 \\
\hline 2-Pentanol & 2105 & 19880.9 & 15688973 & 22900 & 0.4 \\
\hline \multirow[t]{2}{*}{ 1-Pentanol } & 104871 & 161930.9 & 15688973 & 22900 & 807.5 \\
\hline & MW & Weight (mg) & $\mathrm{mmol}_{\text {sample }}$ & & \\
\hline Methanol & 32.04 & 45.522 & 1.421 & & \\
\hline Ethanol & 46.07 & 50.412 & 1.094 & & \\
\hline 2-Propanol & 60.10 & 5.183 & 0.086 & & \\
\hline 1-Propanol & 60.10 & 7.674 & 0.128 & \multirow{3}{*}{$\begin{array}{c}\text { Total Oxygenate } \\
\text { Weight (mg) (based on } \\
\text { sample volume) }\end{array}$} & \multirow{3}{*}{41.68} \\
\hline 2-Butanol & 74.13 & 1.364 & 0.018 & & \\
\hline 1-Butanol & 74.13 & 9.895 & 0.133 & & \\
\hline 2-Pentanol & 88.16 & 0.001 & 0.000 & \multirow{3}{*}{$\begin{array}{c}\text { Total Oxygenate } \\
\text { Weight (mg) (based on } \\
\text { total volume) }\end{array}$} & \multirow{3}{*}{122.42} \\
\hline 1-Pentanol & 88.16 & 2.372 & 0.027 & & \\
\hline Water & 18.01 & 1907.577 & 105.918 & & \\
\hline & & & & $\begin{array}{c}\text { Weight Percent of } \\
\text { Water }\end{array}$ & 93.97 \\
\hline
\end{tabular}


Appendix VIII

Data for Oil Phase

for

Varied K Catalysts 
$6 \% \mathrm{Mo}, 16 \% \mathrm{Fe}, 0.8 \% \mathrm{Cu}, 0.45 \% \mathrm{~K}$

\begin{tabular}{|c|c|c|c|c|}
\hline Injection Volume $(\mu \mathrm{L})$ & 0.1 & Total Volume $(\mu \mathrm{L})$ & \begin{tabular}{l|l|}
650 & Total Weight $(\mathbf{m g})$
\end{tabular} & 400 \\
\hline
\end{tabular}

\section{\begin{tabular}{|l|r|}
\hline Correction factor & 0.348281312 \\
\hline
\end{tabular}}

\begin{tabular}{|c|c|c|c|c|c|c|c|c|}
\hline Compound & MW & $\begin{array}{c}\text { Weight Percent } \\
\text { from GC }\end{array}$ & Area & $\begin{array}{c}\text { Weight in } \\
\text { injection }(\mu \mathrm{g})\end{array}$ & $\begin{array}{c}\text { Weight in } \\
\text { Sample (mg) }\end{array}$ & \begin{tabular}{|c|}
$\begin{array}{c}\text { Corrected Weight } \\
\text { in Sample (mg) }\end{array}$ \\
\end{tabular} & $\begin{array}{c}\text { Amount in } \\
\text { Moles (mmols) }\end{array}$ & $\begin{array}{l}\text { Weight } \\
\text { Percent } \\
\end{array}$ \\
\hline $\mathrm{C}_{6 \text { (parafin) }}$ & 86.20 & 2.6966 & 79162 & 4.582 & 29.781 & 10.372 & 0.120 & 2.773 \\
\hline $\mathrm{C}_{7 \text { (i-parafin) }}$ & 100.23 & 1.1259 & 33051 & 1.631 & 10.600 & 3.692 & 0.037 & 0.987 \\
\hline$C_{7 \text { (parafin) }}$ & 100.23 & 12.0123 & 352629 & 22.082 & 143.536 & 49.991 & 0.499 & 13.367 \\
\hline $\mathrm{C}_{7 \text { (olefin) }}$ & 98.21 & 0.9507 & 27909 & 1.302 & 8.461 & 2.947 & 0.030 & 0.788 \\
\hline $\mathrm{C}_{8 \text { (i-parafin) }}$ & 114.26 & 1.6777 & 49250 & 2.667 & 17.339 & 6.039 & 0.053 & 1.615 \\
\hline$C_{8 \text { (parafin) }}$ & 114.26 & 16.9452 & 497437 & 31.350 & 203.772 & 70.970 & 0.621 & 18.977 \\
\hline $\mathrm{C}_{8 \text { (olefin) }}$ & 112.24 & 2.1884 & 64241 & 3.627 & 23.574 & 8.211 & 0.073 & 2.195 \\
\hline$C_{9 \text { (parafin) }}$ & 128.29 & 14.6976 & 431457 & 27.127 & 176.327 & 61.411 & 0.479 & 16.421 \\
\hline$C_{9 \text { (olefin) }}$ & 126.27 & 4.0899 & 120062 & 7.199 & 46.795 & 16.298 & 0.129 & 4.358 \\
\hline $\mathrm{C}_{10 \text { (parafin) }}$ & 142.32 & 10.9826 & 322400 & 20.148 & 130.962 & 45.612 & 0.320 & 12.196 \\
\hline $\mathrm{C}_{10 \text { (olefin) }}$ & 140.30 & 3.3841 & 99342 & 5.873 & 38.176 & 13.296 & 0.095 & 3.555 \\
\hline $\mathrm{C}_{11 \text { (parafin) }}$ & 156.35 & 7.2262 & 212129 & 13.091 & 85.092 & 29.636 & 0.190 & 7.924 \\
\hline $\mathrm{C}_{11 \text { (olefin) }}$ & 154.33 & 2.6167 & 76816 & 4.432 & 28.805 & 10.032 & 0.065 & 2.683 \\
\hline $\mathrm{C}_{12 \text { (parafin) }}$ & 170.38 & 3.5269 & 103535 & 6.141 & 39.920 & 13.903 & 0.082 & 3.718 \\
\hline $\mathrm{C}_{12 \text { (olefin) }}$ & 168.36 & 1.6949 & 49755 & 2.700 & 17.549 & 6.112 & 0.036 & 1.634 \\
\hline $\mathrm{C}_{13 \text { (parafin) }}$ & 184.41 & 2.0592 & 60450 & 3.384 & 21.998 & 7.661 & 0.042 & 2.049 \\
\hline $\mathrm{C}_{13 \text { (olefin) }}$ & 182.39 & 1.1531 & 33851 & 1.682 & 10.933 & 3.808 & 0.021 & 1.018 \\
\hline $\mathrm{C}_{14 \text { (parafin) }}$ & 198.44 & 1.5933 & 46774 & 2.509 & 16.309 & 5.680 & 0.029 & 1.519 \\
\hline $\mathrm{C}_{14 \text { (olefin) }}$ & 196.42 & 0.973 & 28562 & 1.344 & 8.733 & 3.042 & 0.015 & 0.813 \\
\hline $\mathrm{C}_{15 \text { (parafin) }}$ & 212.47 & 1.0505 & 30838 & 1.489 & 9.680 & 3.371 & 0.016 & 0.901 \\
\hline$C_{15 \text { (olefin) }}$ & 210.45 & 0.7047 & 20687 & 0.840 & 5.457 & 1.901 & 0.009 & 0.508 \\
\hline & & & Total & 165.200 & 1073.797 & 373.984 & 2.960 & 100.000 \\
\hline
\end{tabular}


$6 \% \mathrm{Mo}, 16 \% \mathrm{Fe}, 0.8 \% \mathrm{Cu}, 1.8 \% \mathrm{~K}$

Injection Volume $(\mu \mathrm{L})$

\begin{tabular}{l|l}
0.1 & Total Volume $(\mu \mathrm{L})$
\end{tabular}

2700 Total Weight (mg)

\section{\begin{tabular}{|l|l|} 
Correction factor & 0.934201599 \\
\hline
\end{tabular}}

\begin{tabular}{|c|c|c|c|c|c|c|c|c|}
\hline Compound & MW & $\begin{array}{c}\text { Weight Percent } \\
\text { from GC }\end{array}$ & Area & $\begin{array}{c}\text { Weight in } \\
\text { injection }(\mu \mathrm{g})\end{array}$ & $\begin{array}{c}\text { Weight in } \\
\text { Sample (mg) }\end{array}$ & $\begin{array}{c}\text { Corrected Weight } \\
\text { in Sample }(\mathrm{mg})\end{array}$ & $\begin{array}{c}\text { Amount in } \\
\text { Moles (mmols) }\end{array}$ & $\begin{array}{l}\text { Weight } \\
\text { Percent }\end{array}$ \\
\hline $\mathrm{C}_{6 \text { (parafin) }}$ & 86.20 & 2.3045 & 44673 & 2.375 & 64.113 & 59.895 & 0.695 & 2.715 \\
\hline $\mathrm{C}_{7 \text { (parafin) }}$ & 100.23 & 5.7927 & 112295 & 6.702 & 180.957 & 169.050 & 1.687 & 7.663 \\
\hline $\mathrm{C}_{7 \text { (olefin) }}$ & 98.21 & 5.6704 & 109923 & 6.550 & 176.858 & 165.221 & 1.682 & 7.490 \\
\hline $\mathrm{C}_{8 \text { (parafin) }}$ & 114.26 & 7.5219 & 145874 & 8.851 & 238.977 & 223.253 & 1.954 & 10.120 \\
\hline $\mathrm{C}_{8 \text { (olefin) }}$ & 112.24 & 6.2443 & 121049 & 7.262 & 196.083 & 183.181 & 1.632 & 8.304 \\
\hline $\mathrm{C}_{9 \text { (olefin) }}$ & 126.27 & 5.2576 & 101922 & 6.038 & 163.033 & 152.306 & 1.206 & 6.904 \\
\hline $\mathrm{C}_{10 \text { (parafin) }}$ & 142.32 & 6.0932 & 118120 & 7.075 & 191.022 & 178.453 & 1.254 & 8.090 \\
\hline $\mathrm{C}_{10 \text { (olefin) }}$ & 140.30 & 4.2579 & 82542 & 4.798 & 129.547 & 121.023 & 0.863 & 5.486 \\
\hline $\mathrm{C}_{11 \text { (parafin) }}$ & 156.35 & 4.8659 & 94329 & 5.552 & 149.913 & 140.049 & 0.896 & 6.349 \\
\hline $\mathrm{C}_{11 \text { (olefin) }}$ & 154.33 & 3.3168 & 64297 & 3.630 & 98.021 & 91.572 & 0.593 & 4.151 \\
\hline $\mathrm{C}_{12 \text { (parafin) }}$ & 170.38 & 2.2205 & 43045 & 2.270 & 61.300 & 57.267 & 0.336 & 2.596 \\
\hline $\mathrm{C}_{13 \text { (parafin) }}$ & 184.41 & 2.9023 & 56262 & 3.116 & 84.138 & 78.602 & 0.426 & 3.563 \\
\hline $\mathrm{C}_{13 \text { (olefin) }}$ & 182.39 & 1.967 & 38131 & 1.956 & 52.809 & 49.335 & 0.270 & 2.236 \\
\hline $\mathrm{C}_{14 \text { (parafin) }}$ & 198.44 & 2.4899 & 48268 & 2.605 & 70.325 & 65.698 & 0.331 & 2.978 \\
\hline $\mathrm{C}_{14 \text { (olefin) }}$ & 196.42 & 1.4521 & 28150 & 1.317 & 35.563 & 33.223 & 0.169 & 1.506 \\
\hline $\mathrm{C}_{15 \text { (parafin) }}$ & 212.47 & 2.0013 & 38795 & 1.998 & 53.957 & 50.407 & 0.237 & 2.285 \\
\hline $\mathrm{C}_{15 \text { (olefin) }}$ & 210.45 & 1.1183 & 21680 & 0.903 & 24.384 & 22.780 & 0.108 & 1.033 \\
\hline $\mathrm{C}_{16 \text { (parafin) }}$ & 226.50 & 1.6147 & 31302 & 1.519 & 41.010 & 38.311 & 0.169 & 1.737 \\
\hline $\mathrm{C}_{16 \text { (olefin) }}$ & 224.48 & 0.8253 & 15999 & 0.540 & 14.568 & 13.609 & 0.061 & 0.617 \\
\hline
\end{tabular}




\begin{tabular}{|c|c|c|c|c|c|c|c|c|}
\hline $\mathrm{C}_{17 \text { (parafin) }}$ & 240.53 & 1.3213 & 25614 & 1.155 & 31.181 & 29.130 & 0.121 & 1.321 \\
\hline $\mathrm{C}_{17 \text { (olefin) }}$ & 238.51 & 0.5767 & 11180 & 0.231 & 6.241 & 5.830 & 0.024 & 0.264 \\
\hline $\mathrm{C}_{18 \text { (parafin) }}$ & 254.56 & 1.0708 & 20758 & 0.844 & 22.791 & 21.291 & 0.084 & 0.965 \\
\hline $\mathrm{C}_{18 \text { (olefin) }}$ & 252.54 & 0.4038 & 7829 & 0.017 & 0.451 & 0.421 & 0.002 & 0.019 \\
\hline $\mathrm{C}_{19 \text { (parafin) }}$ & 268.59 & 0.8594 & 16659 & 0.582 & 15.708 & 14.675 & 0.055 & 0.665 \\
\hline $\mathrm{C}_{20+}$ & 282.62 & 2.2995 & 44579 & 2.369 & 63.951 & 59.743 & 0.211 & 2.708 \\
\hline
\end{tabular}

John $\mathrm{H}$.

Hagen 